Coleção Micropolítica do Trabalho e o Cuidado em Saúde

Tatiana Ramminger

Martinho Silva

Organizadores

\title{
Mais substâncias para o trabalho em saúde com usuários de drogas
}

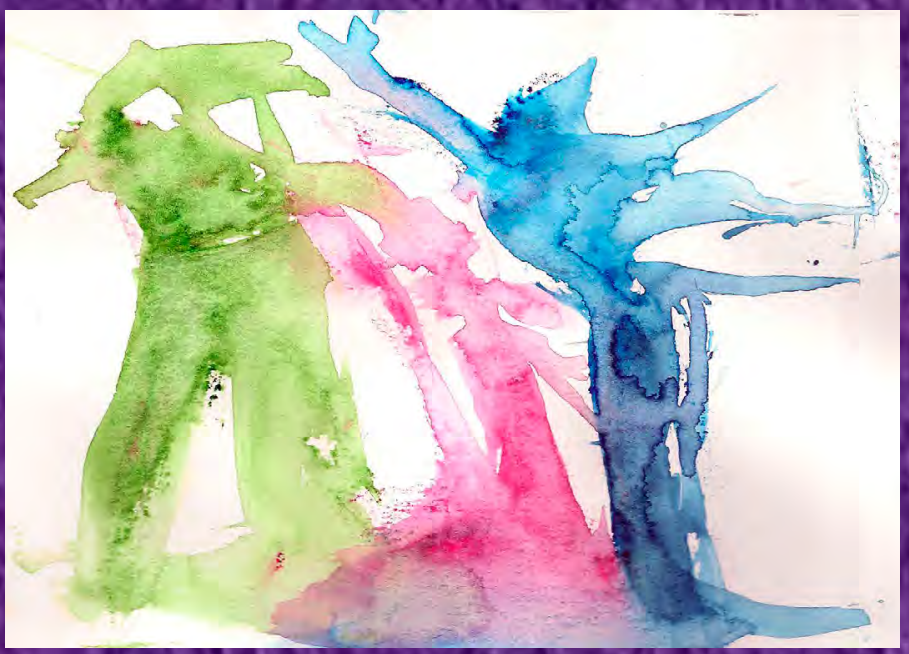

editora

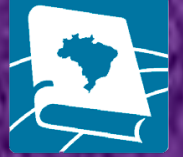

rede unida 

Coleção Micropolítica do Trabalho e o Cuidado em Saúde

\author{
Tatiana Ramminger \\ Martinho Silva
}

Organizadores

\title{
Mais substâncias para o trabalho em saúde com usuários de drogas
}

1a Edição

Porto Alegre, 2014

Rede UNIDA 
Coordenador Nacional da Rede Unida

Alcindo Antônio Ferla

\section{Coordenação Editorial}

Alcindo Antônio Ferla

\section{Conselho Editorial}

Adriane Pires Batiston - Universidade Federal de Mato Grosso do Sul, Brasil Alcindo Antônio Ferla - Universidade Federal do Rio Grande do Sul, Brasil Àngel Martínez-Hernáez - Universitat Rovira i Virgili, Espanha

Angelo Steffani - Universidade de Bolonha, Itália

Ardigó Martino - Universidade de Bolonha, Itália

Berta Paz Lorido - Universitat de les Illes Balears, Espanha

Celia Beatriz Iriart - Universidade do Novo México, Estados Unidos da América

Dora Lucia Leidens Correa de Oliveira - Universidade Federal do Rio Grande do Sul, Brasil

Emerson Elias Merhy - Universidade Federal do Rio de Janeiro, Brasil Izabella Barison Matos - Universidade Federal da Fronteira Sul, Brasil João Henrique Lara do Amaral - Universidade Federal de Minas Gerais, Brasil Julio César Schweickardt - Fundação Oswaldo Cruz/Amazonas, Brasil Laura Camargo Macruz Feuerwerker - Universidade de São Paulo, Brasil Laura Serrant-Green - University of Wolverhampton, Inglaterra Leonardo Federico - Universidade de Lanus, Argentina

Lisiane Böer Possa - Universidade Federal do Rio Grande do Sul, Brasil Liliana Santos - Universidade Federal da Bahia, Brasil

Mara Lisiane dos Santos - Universidade Federal de Mato Grosso do Sul, Brasil Márcia Regina Cardoso Torres - Secretaria Municipal de Saúde do Rio de Janeiro, Brasil

Marco Akerman - Universidade de São Paulo, Brasil

Maria Luiza Jaeger - Associação Brasileira da Rede UNIDA, Brasil

Maria Rocineide Ferreira da Silva - Universidade Estadual do Ceará, Brasil

Ricardo Burg Ceccim - Universidade Federal do Rio Grande do Sul, Brasil

Rossana Staevie Baduy - Universidade Estadual de Londrina, Brasil

Sueli Goi Barrios - Universidade Federal de Santa Maria, Brasil

Túlio Batista Franco - Universidade Federal Fluminense, Brasil

Vanderléia Laodete Pulga - Universidade Federal da Fronteira Sul, Brasil

Vera Lucia Kodjaoglanian - Fundação Oswaldo Cruz/Pantanal, Brasil

Vera Rocha - Universidade Federal do Rio Grande do Sul, Brasil
Comissão Executiva Editorial Janaina Matheus Collar João Beccon de Almeida Neto

\author{
Arte gráfica - Capa \\ Incorporar \\ Kathleen Tereza da Cruz \\ Diagramação \\ Luciane de Almeida Collar

\section{Revisão Técnica} \\ Jacira Gil Bernardes \\ Grafia atualizada segundo o \\ Acordo Ortográfico da Língua \\ Portuguesa de 1990, que entrou \\ em vigor no Brasil em 2009.
}

Copyright (C) 2014 by Tatiana Ramminger e Martinho Silva

\section{DADOS INTERNACIONAIS PARA CATALOGAÇÃO NA PUBLICAÇÃO (CIP)}

M231 Mais substâncias para o trabalho em saúde com usuários de drogas / Tatiana Ramminger, Martinho Silva, organizadores. - 1.ed. - Porto Alegre: Rede UNIDA, 2014.

252 p. : il. - (Coleção Micropolítica do Trabalho e o Cuidado em Saúde)

ISBN 978-85-66659-32-0

1.Vulnerabilidade em saúde. 2. Usuários de drogas. 3. Saúde mental. 4. Transtornos relacionados ao uso de Substâncias. I. Ramminger, Tatiana. II. Silva, Martinho. III. Série.

CDU: 613.8

NLM: WM270

Bibliotecária responsável: Jacira Gil Bernardes - CRB 10/463

Todos os direitos desta edição reservados à ASSOCIAÇÃO BRASILEIRA REDE UNIDA Rua São Manoel, no 498 - CEP 90620-110 - Porto Alegre - RS Fone: (51) 3391-1252 - 


\section{Sumário}

Apresentação - Uma conversa com Tatiana e com todos que aqui estão. 7

Introdução.

Parte I - Um problema político, histórico e social. 25

Modos de trabalhar em saúde mental: pensando os desafios das reformas sanitária e psiquiátrica para o cuidado de pessoas que usam drogas

Da Punição ao Tratamento: rupturas e continuidades na abordagem do uso de drogas......................................51

Fragmentos da história das drogas e de etnografias com os seus usuários

A Cracolândia como "Communitas" e o frade craqueiro.

Parte II - Cuidado, clínicas e redução de danos.

Algumas diretrizes para a direção de tratamento do recurso subjetivo à substância a partir da Psicanálise 101

Afirmar a clínica com pessoas que usam drogas desde um lugar de resistência. 
Redução de Danos: das técnicas à ética do cuidado

Experiência e cuidado: a experimentação como via de composição entre Redução de Danos e Atenção Básica.

Vulnerabilidades do usuário e vulnerabilidades da atenção: apontamentos iniciais para uma clínica de território na Atenção Básica.

Parte III - Relatos, narrativas e experiências. .181

Acompanhando

Manu:

álcool drogas nos (des)encontros da rede de cuidados. .183

\section{Entre}

paradigmas:

desafios

na constituição de uma política sobre drogas. 197

O programa De Braços Abertos da prefeitura paulistana: surgimento, consolidação e perspectivas

O apoio institucional na implantação de estratégias de redução de danos: por quê e para quê?

A prática da supervisão nos serviços de saúde mental. 241 


\section{Apresentação - Uma conversa com Tatiana e com todos que aqui estão}

Nada fácil. Recebi um emeio da Tatiana horas antes do seu acidente fatal, exatamente me lembrando do compromisso de produzir essa introdução. Como muitos fiquei impactado com tamanha perda.

Aqui, estou eu de volta, um mês depois, consciente que não é nada fácil, mas essa tarefa é amenizada com esse livro e isso me ajuda a enfrentar essa dificuldade. Nele, Tati e seus companheiros avançaram na produção de algo desafiador: mais substâncias para o trabalho em saúde com usuários de drogas.

Porém, por uma questão de puro afeto, antes de produzir meu diálogo com o material, quero só declarar: viva, Tatiana!!!

Isso, Tatiana viva nesse livro. Seu corpo sem órgãos aqui está de um modo belo e provocador. Sei que outros aí estão como autores de toda a produção, mas Tatiana... sim faz falta pelo o que em potência teria como um devir. Quantos outros materiais tão fortes teríamos ainda a usufruir. Sei lá, ninguém pode responder a isso, mas posso sentir e falar sobre isso, me deparando com o que vem pela frente para qualquer leitor dessa rica oferta, nos capítulos a seguir. 
A força desse que aqui está é em si muito significativo nesse momento que vivemos, na sociedade brasileira. Um clima conservador em relação a multiplicidade do modo de viver por parte de uma grande multidão de brasileiros e brasileiras, que tem no preconceito contra a diferença do outro buscado agires fascistas anti-vida, imaginando-se consagrando modos de vidas normais.

Aliás, fenômeno muito típico de posições políticas, éticas, culturais e sociais, em geral, etnocêntricas que só reconhecem no seu identitário os valores de uma boa vida, tomando seus princípios como morais que os outros devem se pautar, senão... pau neles!!!

Vir com essa produção de conhecimento, nesse livro, traz a ousadia de enfrentar, como resistência afirmativa, exatamente isso: furar as práticas e estratégia que produzem da diferença desigualdade, afirmando os muitos repertórios da multiplicidade dos viveres em nós, todos os seres em produção.

Por isso, o que é colocado aqui é um desafio a ser medido pelo enfrentamento que pode produzir das práticas microfascistas cravadas no cotidiano dos processos relacionais, entre os vários coletivos que se constituem como modos de produção de si no se encontrar com os outros, nas conexões de modos de existires, produtoras de mais vida e não de menos, como as práticas dos conservadores efetuam.

Tatiana posiciona, no que expressa nos seus textos, nesse livro, que o mesmo vem para descentrar a própria visão do que são "substâncias" no campo do trabalho em saúde junto aos usuários de drogas. Diz:

"O significado mais conhecido do vocábulo substância é "Qualquer espécie de matéria formada por átomos de elementos específicos em proporções específicas", que "possui um conjunto definido de propriedades e uma 
composição química", relativo justamente à demanda de atualização em novas substâncias citada anteriormente. Este significado de substância é inclusive o mais comum no campo de estudos e intervenções em álcool e drogas de modo que quando falamos de mais substâncias para o trabalho em saúde alguns podem compreender que estamos sugerindo que os trabalhadores façam uso de algo além do café no cotidiano assistencial.

Outro dos significados dicionarizados do termo substância diz respeito ao que é mais importante, indispensável, essencial. É neste último sentido que utilizamos o termo substância no título do nosso livro, apontando para a necessidade de situar pontos mais relevantes para o trabalho em saúde com usuários de drogas, tanto no que diz respeito às atividades que o compõe (as diferentes abordagens clínicas, por exemplo) quanto no que tange à sua finalidade (cuidar das pessoas principalmente, tratar a drogadição se necessário, incluir cidadãos sempre), (...) daquilo que os trabalhadores estão fazendo em seu cotidiano assistencial: eles escutam, observam, telefonam, conversam, cuidam, acompanham, encaminham, acolhem, internam, prescrevem medicamentos, registram procedimentos em documentos, constroem entendimentos e acordos provisórios coletivamente e o que mais?"

Coincidência ou não, quando escrevi um texto: $\mathrm{Em}$ busca do tempo perdido. A micropolítica do trabalho vivo em ato, em saúde (FRANCO e MERHY, 2014), apontava para uma potência inscrita no agir, no mundo do trabalho, que como uma "substância", algo não completamente pegável, que pertencia ao território do mundo das relações com o "outro". Algo que denominei trabalho vivo em ato no campo intercessor do mundo relacional, no qual o outro em mim e eu no outro são inseparáveis, a priori.

Indiquei também que o esforço de fazer essa separação é um ato de força de um sobre o outro, como 
por exemplo, o exercício das relações de poder que o saber tecnológico previamente organizado pelo trabalhador sobre o usuário da sua ação sustenta. Ou seja, naquele encontro, intercessor, de simétricos e iguais na diferença, o exercício do saber poder institui uma separação e instala-se um agir sobre o outro.

E na minha elaboração, ao modo apontado por Tatiana e os vários autores desse livro, coloquei como desafio explorar a desconstrução desse processo do agir sobre o outro, apontando para a possibilidade do agir com o outro.

Apontei a distinção entre os territórios tecnológicos previamente dados para o encontro (tecnologias duras e leve-duras) e os em ato (tecnologias leves e relacionais), apontando nas suas transversalidades a inscrição da potência de fugas do instituído, abrindo o encontro para um acontecimento em ato produtor de novos sentidos para as conexões existenciais de todos que aí se encontram.

Hoje, encontro na tese de doutorado de Xavier Mendonça (2014): Sem Soberania - gestão solidária e força fraca para cuidar de vidas fracas, talvez uma das melhores respostas a esses desafios e os coloco aqui como mais uma abertura para o diálogo que esse livro se propõe, já indicando como o mesmo já me agencia e como deverá agenciar os seus vários leitores, como um intercessor. (DELEUZE, 2002)

Xavier Mendonça indica que ali no encontro chegar forte é anular a potência que um encontro em si possui. Chegar forte é por exemplo chegar com o diagnóstico já sobre o outro, já chegar sabendo tudo do outro, mesmo sem conhecê-lo, é chegar indicando ao outro o que será as suas alternativas de produção de existências, enfim, é chegar sem chegar, pois o outro nesse está forte no encontro é não permitir uma relação simétrica mas desigual.

Com ele, para mim, e creio que é disso que esse livro trata, chegar com abertura para o outro é chegar fraco 
no encontro, para que a potência do encontro em si seja disparadora de acontecimentos não dados, de saberes não sabidos, de relações não previstas.

Desse modo, abrir-se para a simetria do outro em mim e de mim no outro passa a ser um desafio da própria produção no campo do cuidado e como tal algo que podemos ter como estratégia de construção.

$\mathrm{E}$, talvez, o que melhor expressou isso para mim, um dia, foi um trabalhador de consultório de rua que me disse: sabe, eu quando estou chegando na rua para me encontrar com os outros, parto do princípio de que não sei nada do que vai acontecer, quanto mais de quem será o outro que vou encontrar e o que ele tem de riqueza existencial; isso é o meu motor para o meu trabalho de cuidador.

Aí está a grande questão que Tatiana e todos nesse livro colocam: trazer para a cena do campo da produção da saúde a fraqueza dos saberes a priori e a potência de uma substância que se inscreve no encontro com o outro, produzindo mais vida em todos que aí estão.

Por último, uma palavrinha sobre o agir em saúde como, antes de tudo, uma ética, isto é, há que se reconhecer que por isso tudo agir em saúde é um posicionar-se sobre o valor da vida do outro e que ela vale a pena ser intensamente vivida, como qualquer vida.

Isso nos inscreve no cotidiano do nosso agir como militantes antifascistas radicais, pois qualquer vida vale a pena para nós que queremos o que Tatiana sempre quis e lutou até o último minuto de si.

Obrigado Tati por essa oportunidade de conversar contigo.

Aproveitem leitores, pois aí adiante há um joia a ser lapidada em vocês.

Emerson Elias Merhy 


\section{Referências}

FRANCO, TB; MERHY, EE. Sem Soberania: gestão solidária e força fraca para cuidar de vidas fracas Trabalho, Produção do Cuidado e Subjetividade em Saúde. São Paulo: Hucitec, 2013.

DELEUZE, G. Espinosa: Filosofia Prática, São Paulo: Escuta, 2002.

MENDONÇA, P.E.X. Sem Soberania: gestão solidária e força fraca para cuidar de vidas fracas Trabalho. Tese de doutorado. Programa de Pós Graduação de Clínica Médica da UFRJ, 2014. 


\section{Introdução}

Álcool, crack, cocaína, maconha, tabaco e muitas outras substâncias psicoativas fazem parte do cotidiano daqueles que atendem usuários de drogas, do mesmo modo como ansiolíticos, analgésicos, antidepressivos e hipnóticos. Recentemente ofertamos um curso de atualização em álcool e outras drogas para profissionais da rede pública de saúde ${ }^{1}$, escutando dos mesmos que eles gostariam de saber mais informações sobre o impacto dessas substâncias sobre o funcionamento do sistema nervoso central, bem como se 'atualizar' em 'novas substâncias', como o oxi. Neste e em outros diálogos com trabalhadores de saúde, fica evidente a importância atribuída à substância escolhida pelo usuário em tratamento. Nossa proposta, explicitada no título desta coletânea, é trazer outras substâncias para este diálogo, para além daquelas consideradas "drogas".

Ao mesmo tempo, a atenção aos usuários de drogas também tem sido adjetivada de diferentes maneiras: repressivo, manicomial, higienista, entre outros, na medida em que tende a reproduzir as práticas de confinamento que marcaram a história da loucura, com o encaminhamento às comunidades terapêuticas ou as $\mathrm{CARES}^{2}$, no caso do

1 Curso de Atualização em Álcool e Drogas para trabalhadores da região do Médio Paraíba do Rio de Janeiro, sob coordenação geral da Comissão de Integração Ensino-Serviço da região e coordenação técnica de Tatiana Ramminger.

2 Centro de Acolhimento Regionalizado em Álcool e Drogas. 
estado do Rio de Janeiro. Embora este procedimento seja muitas vezes registrado como 'acolhimento' em ofícios e outros documentos governamentais, trata-se de um eufemismo para uma conhecida, costumeira e condenável prática quando nos ocupamos da população psiquiátrica: a exclusão.

Do mesmo modo como essa estratégia de adjetivação é relevante no plano do debate político acerca do processo de reforma psiquiátrica brasileira, denunciando isso que já foi tantas vezes caracterizado como um 'retrocesso' no âmbito das políticas públicas de saúde mental, também se torna necessário algum grau de substantivação do trabalho em saúde com usuários de drogas, ou seja, de descrição e análise daquilo que os trabalhadores estão fazendo em seu cotidiano assistencial: eles escutam, observam, telefonam, conversam, cuidam, acompanham, encaminham, acolhem, internam, prescrevem medicamentos, registram procedimentos em documentos, constroem entendimentos e acordos provisórios coletivamente e o que mais?

O significado mais conhecido do vocábulo substância é "Qualquer espécie de matéria formada por átomos de elementos específicos em proporções específicas", que "possui um conjunto definido de propriedades e uma composição química" ${ }^{3}$, relativo justamente à demanda de atualização em novas substâncias citada anteriormente. Este significado de substância é inclusive o mais comum no campo de estudos e intervenções em álcool e drogas ${ }^{4}$,

3 Segundo o Dicionário informal. Ver: http://www.dicionarioinformal. com.br/subst\%C3\%A2ncia/

4 O Núcleo de Estudos Interdisciplinares sobre Psicoativos é justamente "um núcleo de pesquisas sobre substâncias psicoativas que reúne estudiosos da área de Ciências Humanas, vinculados a diversas instituições, para promover uma reflexão conjunta sobre o tema." (grifo nosso), sendo que também há o Grupo Interdiciplinar de Estudos sobre Substâncias Psicoativas. Ver http://www.neip.info/ e http://www.giesp. ffch.ufba.br/textos.htm. No próprio site da Secretaria Nacional sobre 
de modo que quando falamos de mais substâncias pra o trabalho em saúde alguns podem compreender que estamos sugerindo que os trabalhadores façam uso de algo além do café no cotidiano assistencial. Outro dos significados dicionarizados do termo substância diz respeito ao que é mais importante, indispensável, essencial. É neste último sentido que utilizamos o termo substância no título do nosso livro, apontando para a necessidade de situar pontos mais relevantes para o trabalho em saúde com usuários de drogas, tanto no que diz respeito às atividades que o compõe (as diferentes abordagens clínicas, por exemplo) quanto no que tange à sua finalidade (cuidar das pessoas principalmente, tratar a drogadição se necessário, incluir cidadãos sempre). Além disso, vale a pena grifar que são substâncias no plural, pontos relevantes, não uma substância no singular, um único tema que seria essencial.

Não foi nossa intenção, de modo algum, substituir uma substância pela outra. Muito pelo contrário, o objetivo desse livro é acrescentar mais substâncias para ampliar o conhecimento acerca da questão das drogas - por sinal, não só substâncias, como também mercadorias - e multiplicar as informações a respeito das abordagens disponíveis para lidar com as pessoas com necessidades decorrentes do uso de drogas - dentro e fora dos muros dos serviços de saúde. Assim, este livro é uma coletânea de textos dirigidos

Drogas consta uma definição de drogas como substâncias psicoativas: "As drogas utilizadas para alterar o funcionamento cerebral, causando modificações no estado mental são chamadas drogas psicotrópicas. 0 termo psicotrópicas é formado por duas palavras: psico e trópico. Psico está relacionado ao psiquismo, que envolve as funções do sistema nervoso central; e trópico significa em direção a. Drogas psicotrópicas, portanto, são aquelas que atuam sobre o cérebro, alterando de alguma forma o psiquismo. Por essa razão, são também conhecidas como substâncias psicoativas." (grifo nosso). Ver:

http://www.obid.senad.gov.br/portais/OBID/conteudo/index.php?id_ conteudo $=11250 \&$ rastro $=$ INFORMA\%C3\%87\%C3\%95ES+SOBRE+DROGAS/Defini\%C3\%A7\%C3\%A3o+e+hist\%C3\%B3rico 
para os trabalhadores de saúde que atendem pessoas com necessidades decorrentes do uso de drogas, às equipes multiprofissionais e interdisciplinares.

Além disso, ao falar do trabalho em saúde estamos nos referindo à atuação na rede pública do setor saúde, ao conjunto heterogêneo de atividades que os profissionais lotados nos serviços que compõe o Sistema Único de Saúde (SUS) executam para e com a população. Ao especificar o trabalho em saúde do qual nos referimos, como aquele com usuários de drogas, não estamos afirmando que o uso de drogas é ou deva ser uma questão de saúde mental, nem sequer que deveria ser considerado um problema social, embora regularmente seja reconhecido como questão de segurança e saúde pública. Embora o uso de drogas costume ser caracterizado como um problema de polícia por conta de nossa legislação nacional e das normativas internacionais, consideramos que apenas quando ele representa um problema para a pessoa que consome as substâncias psicoativas ou quando ela apresenta alguma necessidade de cuidado decorrente dessa prática é que este uso transforma-se em uma questão de saúde pública. Pleonasmos como 'uso abusivo' ou 'uso de drogas' fazem crer que apenas por fazer uso de uma substância psicoativa uma pessoa deva ser encaminhada para tratamento, sem dúvida um dos equívocos de certos programas em implementação no país. Embora todos os usuários de drogas devam ser informados sobre as possibilidades de se prevenir e não adquirir agravos como hepatites e outras doenças infectocontagiosas, na direção da redução de danos, nem todos devem ser tratados como se o seu consumo fosse abusivo, quanto mais como se tivessem algum problema de saúde mental.

Nossa visão sobre a produção de conhecimento, foucaultiana por excelência, não hierarquiza ciência e demais saberes, de modo que entre os textos que fazem 
parte da coletânea encontraremos uma heterogeneidade de campos, disciplinas e regimes discursivos: alguns são produtos de pesquisas da área de psicologia social, outros de antropologia social, outros ainda de saúde coletiva, sendo que também há relatos, experiências e narrativas sobre a atuação na gestão, supervisão e apoio institucional, bem como sínteses de estudos sobre drogas que não costumam ser muito acessíveis aos trabalhadores do SUS.

Também não consideramos a nossa coletânea de textos sobre drogas algo que venha a substituir outras já disponíveis na literatura acadêmica e jornalística. Outros livros e guias elaborados por jornalistas, bem como coletâneas de textos organizados por médicos e cientistas sociais, também tem colaborado em muito para essa "dessubstancialização" - no sentido de tirar o foco da discussão das substâncias psicoativas - do debate sobre as drogas e para a ofertar mais substâncias - no sentido de mais elementos fundamentais - para "desinstitucionalizar" o trabalho em saúde com usuários de drogas. Esse é o caso de um livro da coleção "Para Saber Mais", da editora Abril, segundo o autor, mais voltada para compreender as pessoas e como nos relacionamos com as drogas do que as próprias e seus compostos químicos (VERGARA, 2003, p. 9 ), e no qual lemos que "As drogas ilegais matam milhares de pessoas todo ano, mas esse estrago é menor do que o estrago causado pelas principais drogas legais, o álcool e o cigarro" (VERGARA, 2003, p. 83 ), algo muito relevante de se levar em conta no trabalho em saúde com usuários de drogas, por vezes centrado até demais em drogas ilícitas como o crack.

Ainda sobre o mercado legal de drogas, outro jornalista comenta o lobby contra tributação de bebidas alcoólicas nos EUA através do exemplo de uma cervejaria que garantia que não fecharia fábricas nos EUA com a condição de que não houvesse aumento de impostos: "A cada lei proposta 
nesse sentido, políticos e líderes sindicais se apavoraram com a possibilidade de a empresa, controladora de $80 \%$ do mercado, começar uma onda de demissões e vetam a medida." (ARAÚJO, 2012, p. 94-95). Também sobre as drogas legais, a recente coletânea organizada por um médico psiquiatra e sanitarista sobre o que ele chama de processos de alcoolização - com base no conceito do pesquisador mexicano Eduardo Menéndez - mostrar a necessidade de "contextualizar a prática de consumo de álcool na cultura e na história, e não apenas o uso problemático", bem como de "apreender o significado cultural atribuído ao consumo de bebidas alcoólicas e às motivações para beber, às situações de consumo e aos circuitos de embebedamento." (SOUZA, 2013, p. 22) Sem falar na conhecida coletânea de textos organizada pelos pesquisadores do Núcleo de Estudos Interdisciplinares sobre Psicoativos (LABATE et al., 2008), também citada em nossa coletânea.

Os catorze textos que compõe essa coletânea foram escritos por professores, pesquisadores, gestores e supervisores envolvidos no debate sobre a questão das drogas na região sudeste do país, muitos deles sendo psicólogos de formação (embora também sociólogos, enfermeiros e médicos) e alguns deles desenvolvendo estudos e intervenções com e não apenas sobre usuários de drogas. Além dos cinco professores que formaram a equipe docente do mencionado curso de atualização em álcool e outras drogas, outros autores foram incluídos pela afinidade de suas pesquisas e ações com o objetivo do livro, qual seja, ofertar mais substâncias para o cuidado de pessoas com necessidades decorrentes do uso de drogas. Independente do atual vínculo institucional tratase, sobretudo, de trabalhadores de saúde dialogando com trabalhadores de saúde, pois todos os autores tiveram e ainda tem a rede de saúde pública como campo privilegiado de atuação e formação. 
A primeira parte da coletânea, "Um problema político, histórico e social", é composta por quatro textos que colocam o debate sobre a questão das drogas em três planos: das políticas públicas de saúde mental; dos processos de medicalização e criminalização; da experiência dos usuários com as substâncias. A segunda parte, "Cuidado, clínicas e redução de danos", é composta por cinco textos que apontam algumas das diferentes abordagens terapêuticas disponíveis para o cuidado de pessoas com problemas decorrentes do uso de drogas, entre elas a psicanálise lacaniana, a redução de danos e a clínica de território. Finalmente, a terceira parte, "Relatos, narrativas e experiências", formada por mais cinco textos, problematiza iniciativas de atenção, gestão, apoio e supervisão no setor saúde de um modo pouco convencional, contando estórias mais do que historicizando, politizando ou sociologizando fenômenos.

Em "Modos de trabalhar em saúde mental: pensando os desafios das reformas sanitária e psiquiátrica para o cuidado de pessoas que usam drogas", Tatiana Ramminger dá início ao debate sobre as drogas com os trabalhadores em saúde por meio de um ponto fundamental para o cotidiano assistencial: os princípios e diretrizes apontadas pelas políticas públicas de saúde e de saúde mental. É assim que se mostra pertinente recolocar o tema das drogas no interior tanto na reforma sanitária quanto da psiquiátrica, para que não venhamos a nos esquecer de quais são os vetores político-institucionais que sustentam propostas tão divergentes quanto consultórios na rua e comunidades terapêuticas.

Segue-se "Da punição ao tratamento: rupturas e continuidades na abordagem do uso de drogas", texto no qual Cláudia Ciribelli questiona em que medida o discurso em torno da descriminalização e legalização das drogas, 
pautado no argumento de que o uso de drogas é uma questão de saúde e não de polícia, rompe efetivamente com o modelo repressivo. Após sublinhar algumas falas dos próprios representantes do governo federal acerca da internação compulsória de usuários de drogas, conclui que há continuidade na cumplicidade descrita por Foucault, desde o século XIX, entre Justiça e Medicina, e que a ruptura com o modelo repressivo vai muito além do acento no tratamento ou na punição, dependendo da construção de uma nova ética do cuidado.

A perspectiva política-institucional sobre o fenômeno das drogas permeou do texto de Tatiana Ramminger e a histórica se fez presente no de Cláudia Ciribelli, de modo que em "Fragmentos da história das drogas e de etnografias com os seus usuários", Martinho Silva acentua ainda mais esta última perspectiva e acrescenta também pesquisas sobre aquilo que os próprios usuários dizem do consumo que fazem, condensando uma literatura internacional e principalmente nacional sobre a história e a antropologia das drogas.

A perspectiva etnográfica singular desenvolvida por Ygor Alves para compreender o problema social das drogas fica patente em "A Cracolândia como 'Communitas' e o frade craqueiro", radicalizando o ponto de vista que os habitantes da dita "cracolândia" tem de si, dos outros, das substâncias e dos espaços nos quais consomem o crack. Essa dimensão espacial e relacional ganha relevo em uma narrativa cheia de detalhes sobre as próprias expressões utilizadas pelos que estão procurando uma biqueira para dar um trago.

Em "Algumas diretrizes para a direção de tratamento do recurso subjetivo à substância a partir da Psicanálise", Cláudia Henschel de Lima mostra o potencial da abordagem psicanalítica - particularmente lacaniana - para construir uma compreensão do funcionamento pulsional do sujeito 
que consome a droga, distanciando-se da psiquiatria biológica contemporânea e seu crescente número de categorias diagnósticas para classificar este sujeito. Além de uma denúncia da moral higienista, seu texto aponta para a possibilidade de tratar o recurso à droga com base na tradicional divisão neurose-psicose, bem como contém comentários didáticos sobre casos clínicos publicados.

Flávia Fernando Lima Silva, em "Afirmar a clínica com pessoas que usam drogas desde um lugar de resistência", apresenta a ideia de uma clínica construída junto com as pessoas que usam drogas. A construção dessa clínica é um lugar de resistência. Frente aos discursos hegemônicos, designados como discursos maiores, que se preocupam mais com a substância que com o sujeito ou seu contexto, a autora nos convida à radicalidade da escuta dos discursos menores, daquilo que se pode produzir no encontro com o usuário, apostando na saúde como autonomia e ampliação de mundo.

Mais uma das abordagens para lidar com usuários de drogas, como a clínica que investe nos sujeitos e a aquela que aposta nos encontros, a redução de danos é apresentada por Dênis Petuco através de seus três nascimentos em "Redução de Danos: das técnicas à ética do cuidado". O primeiro nascimento na Inglaterra com a terapia de substituição, o segundo na Holanda com a maior ênfase no meio de utilização da droga e não tanto na própria droga e o terceiro no Brasil, este último merecendo também a descrição de três cenas, narradas por um dos principais protagonistas desse processo de difusão da perspectiva da redução de danos e de criação de uma clínica freireana no país, Dênis Petuco.

Os dois últimos textos desta segunda parte do livro, sobre as clínicas com usuários de drogas, são complementares. Em "Experiência e cuidado como via de 
composição entre Redução de Danos e Atenção Básica", Rafael Dias e lacã Macerata apostam em um cuidado da experiência com a droga, que só pode ser construído localmente, a partir do conhecimento da experiência do sujeito e de seu território de relações. Para tanto propõe que a articulação entre redução de danos e atenção básica possa criar condições para a experiência do cuidado. Em "Vulnerabilidades do usuário e vulnerabilidades da atenção: apontamentos iniciais para uma clínica de território na Atenção Básica", lacã Macerata problematiza a substituição da expressão 'população de risco' para 'população vulnerável' quando nos referimos a pessoas em situação de rua e àquelas com necessidades decorrentes do uso de drogas, bem como o deslocamento da vulnerabilidade do sujeito para as condições sociais como alvo das ações das equipes de atenção básica. Atento às vulnerabilidades da própria rede de saúde, o autor aposta em uma clínica que deslocaliza o problema sanitário e imerge no território de vida dos usuários do SUS.

Aisllan Assis, em "Acompanhando Manu", materializa justamente uma dessas essas populações vulneráveis através na narrativa de um caso de alcoolismo em atendimento na rede de atenção em saúde de uma das principais metrópoles brasileiras. Os trechos de sua etnografia usuariocentrada nos revelam os encontros e desencontros entre cuidadores, familiares, usuária e pesquisador nos serviços de saúde, onde ainda parece haver pouco lugar para fazer caber pessoas que saíram de hospitais psiquiátricos e viabilidade na agenda para os que portam alguma doença infecto-contagiosa, nos transportando para o universo das comorbidades.

Ana Cecília Guilhon e Pedro Henrique Antunes da Costa relatam passo-a-passo as iniciativas de uma gestão municipal em saúde para lidar com as drogas em "Entre 
paradigmas: desafios na constituição de uma política sobre drogas", algo que aproxima os leitores do próprio cotidiano de um espaço decisório coletivo e heterogêneo. As articulações entre secretarias e departamentos, bem como as alianças entre especialistas, gestores, representantes de casas de recuperação e lideranças locais, destacam-se nesse cenário administrativo mobilizado em torno da elaboração de uma política municipal sobre drogas.

Mais uma vez Ygor Alves apresenta os resultados de sua etnografia com usuários de crack na cidade de São Paulo-SP em "O programa De Braços Abertos da prefeitura paulistana: surgimento, consolidação e perspectivas", também mostrando articulações entre setores - saúde, assistência social e trabalho - e alianças entre pessoas com distintos pertencimentos institucionais (governo e ONGs), com a diferença de quem olha para o programa sendo implantado após conhecer o cotidiano dos seus beneficiários. As potencialidades e limitações dessa que é uma das principais iniciativas governamentais para abordar o problema social, sanitário e de segurança colocado pelo consumo de crack nas grandes metrópoles emergem da descrição detalhada e cuidadosa do autor.

Em "O apoio institucional na implantação de estratégias de redução de danos: por quê e para quê?", Marcelo Dalla Vecchia nos convida a conhecer como o apoio institucional pode ser potente ferramenta para a coletivização das análises e decisões no trabalho em saúde. Os três episódios apresentados são ricos de informações sobre a dinâmica e os impasses desta atividade baseada nos princípios da humanização em saúde, um instrumento para obter encaminhamentos consensuados, inclusive em meio a situações tensas e discussões acaloradas.

Finalmente, em "A prática da supervisão nos serviços", Maria Wilma Faria chama a nossa atenção para 
a abordagem dos casos graves em álcool e outras drogas, segundo ela, aqueles que fazem um furo no ideal da instituição, recomendando que se lide com os casos um a um e evite-se encaixar o usuário em alguma regra de ouro da instituição.

Que cada um dos textos, de diferentes maneiras, possa contribuir e dialogar com os trabalhadores de saúde mental, ampliando o cuidado, reduzindo os danos e colocando o sujeito em foco e não a substância por ele utilizada.

\section{Referências}

ARAÚJO, T. Almanaque das drogas - um guia informal para o debate racional. São Paulo: Leya, 2012.

LABATE, B. et al. (orgs.). Drogas e cultura: novas perspectivas. Salvador: EDUFBA, 2008.

SOUZA, Maximiliano (org.). Processos de alcoolização indígena no Brasil: perspectivas plurais. Rio de Janeiro: FIOCRUZ, 2013.

VERGARA, R. Drogas. São Paulo: Editora Abril, 2003. 


\section{Parte I}

\section{Um problema político, histórico e social}





\section{Modos de trabalhar em saúde mental: pensando os desafios das reformas sanitária e psiquiátrica para o cuidado de pessoas que usam drogas}

Tatiana Ramminger

\section{Introdução}

O início do século XXI apresentou um novo desafio ao trabalhador de saúde mental: agora ele deveria não apenas cuidar de pessoas com sofrimento ou transtorno mental, mas também de pessoas com "necessidades decorrentes do uso de crack, álcool e outras drogas." (BRASIL, Ministério da Saúde, 2011) Em outros artigos dessa coletânea, será possível problematizar sobre a recente transformação do uso de drogas em um problema de saúde pública, mais especificamente, um problema de saúde mental, bem como algumas estratégias de cuidado das pessoas que usam drogas. Nesse capítulo nosso objetivo é compreender os diferentes discursos que forjam o trabalho e o trabalhador de saúde mental, identificando os saberes que sustentaram, em diferentes épocas, o cuidado em saúde mental. A importância de acompanhar este percurso é compreender alguns princípios organizadores desta experiência, ou seja, uma genealogia do presente, onde o retorno ao passado 
justifica-se na medida em que nos ajuda a entender o que somos hoje.

Quem é aquele que hoje é convocado ao cuidado de pessoas que usam drogas? Quais os princípios e diretrizes que regem o seu trabalho? Sob que contexto este trabalho se constituiu e é realizado? A partir destas perguntas, buscaremos vislumbrar as rupturas, continuidades, contradições, lutas e acasos que configuraram o atual campo de saúde mental, onde se destacam os discursos das reformas sanitária e psiquiátrica.

\section{Reforma Sanitária e Saúde Coletiva no Brasil}

Apesar da ideia naturalizada de que a Saúde Pública e a Saúde Coletiva são sinônimos, posto que ambas remetem à impossibilidade de se pensar em uma saúde individual sem considerar as condições sanitárias do espaço social, temos boas razões para acreditar que essas expressões não se superpõem, pois dizem respeito a "diferentes modalidades de discurso, com fundamentos epistemológicos diversos e com origens históricas particulares." (BIRMAN, 2005, p. 11)

O movimento de luta pela reforma sanitária no Brasil - que culminou na criação do Sistema Único de Saúde - caracterizou-se, sobretudo, por uma crítica às práticas consagradas da Saúde Pública e pela reivindicação de outro conceito de saúde que, para além do biológico, incluísse a dimensão social na análise do processo saúde-doença. No entanto, para compreender o que esse movimento vislumbrava transformar, comecemos delimitando o campo aqui designado como "Saúde Pública".

Foucault (1999a) nos diz que a Saúde Pública nasce 
junto com o Estado Moderno, quando a população tornase a principal fonte de riqueza para o Estado. Sendo assim, a saúde das populações transforma-se em preocupação política do Estado, tomando diferentes rumos, conforme o país. É na Inglaterra, país em que o desenvolvimento industrial e do proletariado foi o mais rápido e importante, que temos uma nova forma de saúde pública e, não por acaso, aquela que prevaleceu na atualidade. Um "cordão sanitário autoritário" separa ricos e pobres nas cidades, onde a intervenção médica é tanto uma maneira de auxiliar nas necessidades de saúde dos pobres, quanto um controle que assegura a proteção das classes mais abastadas de possíveis doenças e epidemias.

Especialmente no Brasil, a Primeira República (1889-1930) marcou a criação e implementação dos primeiros serviços e programas de saúde pública, em nível nacional. Pautado nas campanhas sanitárias de combate às epidemias urbanas e endemias rurais, com um estilo repressivo de intervenção médica nos corpos individual e social, este modelo tornou-se um dos pilares das políticas de saúde não só no Brasil, mas no continente americano em geral. Consolidou-se uma estrutura administrativa de saúde centralista, tecnoburocrática e corporativista, isto é, ligada a um corpo médico proveniente da oligarquia de origem agrária que dominou a República Velha, pautada em ações episódicas e voltadas para doenças específicas, como febre amarela, tuberculose, lepra e varíola. (LUZ, 1991; PAIM, 2011)

Cabe destacar que esse tipo de intervenção da saúde pública - mais do que um cuidado, um controle médico da população - sempre suscitou resistências, como por exemplo, a "revolta da vacina"1. Como nos alerta Birman

1 Reação da população à Lei da Vacina Obrigatória, promulgada em 31 de outubro de 1904 que permitia que brigadas sanitárias, acompanhadas de policiais, entrassem nas casas e aplicassem a vacina contra a 
(2005), em nome da ciência, tivemos a marginalização de diferentes segmentos sociais, com a consolidação de práticas assépticas que, ao silenciarem considerações de ordem simbólica e histórica na leitura das condições de vida e saúde das populações, fazem crer que não existe uma escolha política, ideológica e ética nas práticas sanitárias.

O ano de 1923 marca o início da Previdência Social, com a criação das Caixas de Aposentadoria e Pensões (CAP), segundo diferentes categorias profissionais, que assegurava a assistência médica aos trabalhadores vinculados a essas Caixas, demonstrando a relação entre a assistência à saúde e a necessidade de manutenção de um corpo suficientemente saudável para permanecer produtivo. O Período Populista (1930-1950) caracterizou-se pela introdução e incremento dos Institutos de Seguridade Social (as antigas CAP) e de programas e serviços de auxílio e de atenção médica impregnados de práticas clientelistas, apoiadas pelos sindicatos que eram, assim como os Institutos, controlados pelo Estado.

Como já nos apontava Foucault (1999a, p. 97) em relação ao modelo de saúde pública inglês, trata-se de uma medicina que é "essencialmente um controle da saúde e do corpo das classes mais pobres para torná-las mais aptas ao trabalho e menos perigosas às classes ricas", ligando "assistência médica ao pobre, controle da saúde da força de trabalho e esquadrinhamento geral da saúde pública", com três sistemas médicos superpostos: uma medicina assistencial para os pobres e trabalhadores; uma medicina administrativa encarregada de problemas mais gerais e, finalmente, uma medicina privada que beneficia quem

varíola, mesmo contra a vontade, em todos daquela residência. Foram duas semanas de intenso conflito nas ruas cariocas, até o governo declarar "estado de sítio" e suspender a obrigatoriedade da vacina. No entanto, o movimento foi contido logo em seguida e a vacinação maciça e obrigatória da população (pobre) teve prosseguimento. 
pode pagar. Mesmo que articulados de maneira diferente, tratava-se (e trata-se!) de fazer funcionar esses três sistemas. Por isso a proposta de um Sistema Único de Saúde, visto que tínhamos diferentes subsistemas de saúde no Brasil, desvinculados entre si: de um lado, as ações voltadas para o ambiente e a coletividade, pautada sobretudo no controle de epidemias e endemias, sob responsabilidade da Saúde Pública; de outro, as ações curativas e individuais ligadas à medicina previdenciária e privilégio apenas daqueles que tinham "carteira de trabalho assinada"; e, finalmente, as modalidades de assistência médica liberal e filantrópica, uma destinada aos que podiam pagar e outra baseada nos princípios da caridade (e não do direito) que atendia aos pobres e desvalidos.

Seguindo esta lógica, o Ministério da Saúde torna-se autônomo em relação ao Ministério da Educação apenas em 1953, sendo que até meados de 1970, seu orçamento não alcançava $1 \%$ dos recursos públicos federais. Do outro lado, em 1966, os Institutos de Pensão existentes são unificados no Instituto Nacional de Previdência Social (INPS) que passou a concentrar as ações de assistência à saúde do trabalhador, privilegiando as ações curativas, individuais e hospitalocêntricas (centradas no hospital).

Entre 1950-60 houve a tentativa de implantar-se um projeto nacional de desenvolvimento econômico moderno, integrado à ordem capitalista, gerando uma crise no regime nacionalista e populista. A saúde exprimia a dicotomia entre o modelo campanhista (baseado em campanhas pontuais de vacinação, por exemplo), que ainda predominava na saúde pública e o modelo curativista (centrado na cura e não na promoção e prevenção à saúde), dominante nos serviços previdenciários de atenção médica. A saída histórica para este impasse, considerado estrutural, foi proposta pelas elites progressistas que lideravam o movimento social do 
início dos anos 1960, reivindicando "reformas de base" imediatas, entre as quais uma reforma sanitária consistente e consequente. No entanto, a reação política das forças conservadoras, levou ao golpe militar de 1964.

Durante o período da ditadura militar a dicotomia existente na saúde pública foi resolvida com uma síntese perversa, "que aliou campanhismo e curativismo numa estratégia de medicalização social sem precedentes na história do país." (LUZ, 1991, p. 81) A principal característica deste período foi a chamada "privatização da saúde", com o surgimento e rápido crescimento de um setor empresarial de serviços médicos centrados na lógica do lucro, financiados pela Previdência Social e com um sistema de atenção massificado. No final do período, as verbas para a saúde pública despencaram e a atenção médica da Previdência Social caminhou a passos largos para a falência. A imagem da medicina como portadora de uma solução miraculosa para as más condições de vida da população começou a ser socialmente questionada e publicamente denunciada.

No contexto das mobilizações em prol do fim do regime militar e da democratização do país, o movimento pela Reforma Sanitária tomou força. Buscando romper com o discurso naturalista e pretensamente neutro da Saúde Pública, este movimento propôs outro campo que se ocupasse da saúde - não mais da massa disforme da população, mas dos sujeitos que compõem um coletivo - a Saúde Coletiva. Essa passagem do público para o coletivo descentra o lugar do Estado como "espaço hegemônico para a regulação da vida e da morte na sociedade", sendo que este não é mais o polo único "na gestão do poder e dos valores", reconhecendo-se "o poder instituinte da vida social, nos seus vários planos e instituições." (BIRMAN, 2005, p. 14) Assim, o campo teórico da Saúde Coletiva pretende ser uma ruptura com a concepção de Saúde Pública, ao negar o monopólio dos discursos biológicos e incluir as dimensões 
simbólica, ética e política na discussão sobre as condições de saúde da população, sendo a transdisciplinaridade sua marca constituinte.

Em março de 1986 ocorre a VIII Conferência Nacional de Saúde, sendo que seu relatório final influiu de forma decisiva na elaboração da nova Constituição Federal, bem como nas diretrizes e princípios do SUS. Em 1988 foi aprovada a nova Constituição Federal, que definiu a saúde como resultante de políticas sociais e econômicas, como direito do cidadão e dever do Estado, como parte da seguridade social, e cujas ações e serviços devem ser providos por um Sistema Único de Saúde, organizado segundo os princípios da descentralização, mando único em cada esfera de governo, atendimento integral, e controle social.

É importante compreendermos como os princípios e diretrizes do SUS, mais do que "palavras de ordem", abordam justamente os principais problemas identificados ao longo da história dos sistemas de saúde brasileiros. Por isso, vamos destacá-los².

- Universalização do direito à saúde: é a garantia de que todos os cidadãos devem ter acesso aos serviços de saúde, independente de vínculo de trabalho, gênero ou classe social;

- Descentralização com direção única para o sistema: é o entendimento de que a gestão dos serviços de saúde deve ser dos municípios, cabendo à União e aos Estados, as diretrizes mais gerais das políticas de saúde. Isto porque quanto mais perto o gestor e os serviços estiverem da população, maior a chance de atender suas reais necessidades de saúde;

2 Para uma discussão mais detalhada sobre os Princípios e Diretrizes, leia o texto "Princípios e Diretrizes do Sistema Único de Saúde", de Gustavo Correa Matta, 2007. 
- Integralidade da atenção à saúde: é o reconhecimento de que o usuário é um ser integral (e não apenas um pé, uma garganta, um pulmão), que deve ser atendido na integralidade de suas necessidades, que incluem ações de promoção, proteção e recuperação da saúde, em diferentes níveis de complexidade: atenção básica (as unidades básicas de saúde e Estratégia de Saúde da Família), a média complexidade (ambulatórios) e alta complexidade (hospitais e emergências);

- Controle Social: é o direito da população participar do processo de formulação das políticas de saúde e do controle de sua execução. Esta participação se dá nos Conselhos de Saúde (municipais, estaduais e nacional) e nas Conferências de Saúde (da mesma forma, municipais, estaduais e nacional).

Sendo assim, o SUS não é uma mera reforma administrativa. Necessita, para afirmar-se em seus princípios, realizar mudanças culturais nas instituições públicas de saúde, sobretudo no que tange ao processo de trabalho, considerando tanto a concepção do processo saúde-doença (saúde como produção social), como o paradigma sanitário (deslocamento da atenção médica e hospitalar para a atenção integral à saúde). Como bem dizia o saudoso Sérgio Arouca: O SUS é um processo civilizatório, que aposta na transformação social. 


\section{A Reforma Psiquiátrica e as mudanças no trabalho em saúde mental}

A reforma psiquiátrica, que nasce no bojo da reforma sanitária, também está pautada em uma mudança no processo de trabalho. Vejamos agora como se constituiu o sistema psiquiátrico no Brasil e as sucessivas transformações no trabalho em saúde mental.

Até o século XVIII, assim na Europa como no Brasil, não existia nenhuma forma de tratamento específico para a loucura, sendo que aos loucos eram destinadas celas insalubres e castigos corporais. Cabe lembrar que a função do hospital também era bem distinta da atual, já que seu objetivo principal não era o cuidado em saúde, e sim a assistência aos pobres, sobretudo daqueles que vão morrer. O hospital era um lugar para morrer - um morredouro. Quem assistia aos doentes eram religiosos ou leigos que não estavam ali para realizar a cura do doente, mas para garantir sua própria salvação. Assim, o discurso religioso, predominante à época, forja um modo de cuidado, onde aquele que "cuida" busca sua própria salvação espiritual, enquanto aquele que é "cuidado" é fixado na posição de coitado, perigoso e inútil para o trabalho, devendo ser afastado do convívio social.

Quando a medicina se organiza como discurso legitimado socialmente, no início do século XVIII, o hospital adquire outro caráter, passando a ser considerado um instrumento terapêutico, de cura. O médico, antes mero coadjuvante, torna-se o principal responsável pela organização hospitalar. Pinel, médico francês, é identificado na literatura especializada como o "pai da psiquiatria". Ele inicia o movimento que ficou conhecido como a primeira "reforma psiquiátrica" da história - o "no restraint" - que consistia em libertar os loucos das celas e correntes. 
Seguindo a perspectiva de Descartes - que instituiu a racionalidade como único modo possível de pensamento e de acesso à verdade - Pinel entendia que a loucura separava o homem de sua própria verdade, posto que agia diretamente sobre a razão. Sendo assim, postula que a loucura é uma doença, mais especificamente, uma doença mental. O homem, na loucura, é um estranho em relação a si mesmo - um alienado de sua verdade, que só poderá Ihe ser restituída pela mão do médico. Por consequência, é o discurso médico psiquiátrico que detém a verdade sobre a loucura, e não o contrário. Ninguém pode dizer-se ou reconhecer-se louco, mas somente ser diagnosticado como tal. (FOUCAULT, 1999b) A loucura não é mais castigo dos deuses, possessão, bruxaria ou júbilo, mas doença mental. Os loucos não mais pertenciam à fogueira mas aos médicos.

Por sua vez, o que afastava o homem de sua razão era um tipo de imoralidade, excesso ou desvio, passível de cura por um "tratamento moral" ${ }^{3}$, sendo necessário um lugar específico e o afastamento do convívio social para esta reeducação. A partir desse momento, a reclusão não é mais apenas fruto de uma demanda social de manutenção da ordem pública, mas justifica-se como dispositivo terapêutico. E esta dupla função - de cuidado e controle, de terapêutica e dominação, proteção e tutela, clínica e política - vai acompanhar não apenas a psiquiatria, mas também as demais disciplinas e tecnologias que se ocupam da loucura. Como bem resumiu Castel (1978): a prática psiquiátrica é a prática de uma contradição: entre uma finalidade terapêutica e certas funções político-administrativas.

3 "Desse modo, o tratamento proposto é moral porque não é físico, porque se exerce sobre o conhecimento (no plano das ideias) e, por consequência, sobre o comportamento resultante. E é moral porque visa a corrigir excessos passionais, desvios da norma ética do grupo social. É assim que o médico se torna ordenador não só da vida (psíquica) do paciente, mas também o agente da ordem social, da moral dominante". (PESSOTTI, 1996, p. 128) 
Sendo assim, a partir do século XIX, é o discurso médico que detém a verdade sobre a loucura, inaugurando o trabalho especializado no cuidado com o que passou a ser denominado "doença mental". O louco, como doente mental, necessitava de tratamento. O tratamento moral, tal qual preconizado por Pinel, tinha dois princípios básicos: o da disciplina e o do isolamento, o que exigia uma organização espacial específica, assim como pessoas que cumprissem o papel da vigilância. Em vários relatórios de um hospital psiquiátrico brasileiro, do fim do século XIX, sempre aparece a necessidade de aumentar o número de empregados, sobretudo para "estabelecer-se a vigilância precisa (...), correspondendo às necessidades que o serviço cria e que a ciência impõe." (RELATÓRIO de 1884, apud WADI, 2002, p. 144)

Dois personagens começam a se destacar no cuidado do "alienado mental": o médico psiquiatra e o enfermeiro psiquiátrico. O primeiro é "o princípio da vida de um hospital de alienados; a ele compete dirigir todas as ações, porque ele deve ser o regulador de todos os pensamentos." (ESQUIROL apud WADI, 2002, p. 174) O segundo, colocado em último lugar na escala hierárquica - e sofrendo, ele mesmo, a vigilância dos que o antecedem nesta escala - era aquele que exercia prioritariamente a função de vigilante, devendo "acompanhar os doentes em todos os lugares e em todos os momentos." (MACHADO, 1978, p. 436) Percebemos, assim, que a organização do trabalho nos hospitais psiquiátricos, desde seu início, fundamenta-se na vigilância e na nítida separação entre os que pensam e os que executam, produzindo relações de poder assimétricas e verticalizadas, ainda hoje evidentes nestas instituições.

A figura e as funções do enfermeiro psiquiátrico, no entanto, permanecem e são construídas no discurso médico de forma idealizada, como podemos perceber na descrição de um médico - DR. SIMONI - publicada na 
Revista Médica Fluminense, em 1839: "um enfermeiro de alienados deve casar a severidade com a doçura, a coragem com a prudência, discrição e caridade e uma certa esfera intelectual para entender o médico e o doente. Deve ser um homem probo, ativo, zeloso, inteligente e com longa experiência." (SIMONI apud MACHADO, 1978, p. 437) No entanto, a realidade que se apresentava era bem diferente:

(...) A circunstância da mesquinhez de ordenados aos empregados inferiores é de alta importância; porque, em regra geral, os indivíduos que dispõe de certos requisitos, que os tornam aptos para 0 desempenho de tais empregos, não se querem sujeitar, de certo, aos sacrifícios que acima falei, para receber um vencimento que não compensa o trabalho, não barateiam tanto os seus serviços. Dr. Lisboa, primeiro diretor do Hospício São Pedro, em relatório de 1884. (SIMONI apud WADI, 2002, p. 146)

Todas estas preocupações tornaram-se problemas crônicos que marcaram a história dos hospitais psiquiátricos brasileiros: a superlotação, a escassez de recursos, a mãode-obra mal remunerada e desqualificada, os abusos de poder...

Com as reflexões sobre as consequências dos regimes totalitários na Europa, após a 2a Guerra Mundial, assistimos a uma ampla mobilização em prol de ideais libertários e humanistas. Discussões sobre cidadania, ampliação dos direitos humanos e liberdade disseminaram-se por todo mundo. Os discursos totalitários, as verdades absolutas, a naturalização das condições de miséria e segregação das populações, são problematizadas, contextualizadas e questionadas em seus efeitos. No seio destas discussões, a psiquiatria vive um momento de crise teórica e prática, que gerou diferentes modelos reformistas, analisados por 
Birman e Costa (1994):

a) crítica à estrutura asilar: manicômio é uma estrutura necessária à cura e torna-se urgente resgatar o caráter positivo da instituição, com uma reforma da instituição psiquiátrica, como nas Comunidades Terapêuticas na Inglaterra e na Psicoterapia Institucional francesa;

b) extensão da psiquiatria ao espaço público, com a Psiquiatria de Setor, na França e a Psiquiatria Comunitária ou Preventiva americana. O objeto da psiquiatria não é mais a doença, mas a saúde mental, aqui ainda definida em termos adaptativos como a capacidade do sujeito integrarse a um grupo;

c) problematização do próprio dispositivo médico e das categorias de saúde e doença mental, com a Antipsiquiatria e a Psiquiatria Democrática Italiana. Nesta perspectiva, ao contrário da vertente preventivista, não se almeja uma adequação ao meio social, mas a produção de formas de sociabilidade que se relacionem de outro modo com a loucura.

O modelo italiano, pautado na proposta de desinstitucionalização, foi a principal referência para a reforma psiquiátrica brasileira não defende a reciclagem, modernização ou humanização do Manicômio, mas sim sua extinção, entendendo que todos os estabelecimentos que seguem seu modelo e as lógicas que justificam sua existência são incompatíveis com uma política de respeito aos direitos humanos. Cabe lembrar que a proposta da desinstitucionalização, não deve ser confundida com a desospitalização, pois não diz respeito ao mero fechamento de um estabelecimento, e sim a um questionamento de um modo de funcionamento cristalizado e opressor. $\mathrm{O}$ alvo de sua crítica, portanto, não é apenas o hospital psiquiátrico, mas a instituição "psiquiatria". Sua proposta é que o acento esteja na experiência de sofrimento do sujeito, e não em 
sua doença, sendo que sua principal linha de ação é a luta política pela transformação no modo como a sociedade se relaciona com a loucura.

No Brasil, esta discussão, não por acaso, toma força no final da década de 1970, após mais de uma década de um totalitário regime militar, com a criação do Movimento dos Trabalhadores de Saúde Mental, que se mobilizaram não só por mudanças no tratamento psiquiátrico, mas também pela reforma sanitária e pela redemocratização política do país. Na década seguinte, esta iniciativa amplia-se em vários sentidos. Usuários e familiares juntam-se aos trabalhadores, dispostos a implicar toda sociedade no questionamento da segregação da loucura. Sob o lema: "Por uma Sociedade sem Manicômios", cria-se o Movimento Nacional da Luta Antimanicomial, claramente inspirado no modelo italiano que, com sua ênfase nos direitos e cidadania do louco, traduzia aquilo que era desejado, também, por grande parte dos brasileiros naquele momento.

Não podemos esquecer da Reforma Sanitária brasileira, que culminou na criação do Sistema Único de Saúde. Curiosamente, não há muitas análises da relação entre as reformas sanitária e psiquiátrica no Brasil. Embora seja reconhecido que a reforma psiquiátrica brasileira foi conduzida à política de governo pelas mãos da reforma sanitária, percebemos uma ênfase muito maior na influência das experiências estrangeiras do que naquelas vivenciadas a partir da implantação de um novo modelo de saúde no país.

Este novo cuidado inclui alguns deslizamentos conceituais que nos dão uma ideia das mudanças pretendidas: do saber médico-psiquiátrico para a interdisciplinaridade, do doente mental para o portador de sofrimento psíquico, dos muros dos hospitais psiquiátricos para a circulação pela cidade, de paciente para usuário, 
da clínica psiquiátrica para a atenção psicossocial, do incapaz tutelado para o cidadão. Exigência não só de novos paradigmas e conceitos, mas igualmente invenção de outros modos de intervir, gerir serviços, relacionar-se, trabalhar. Um outro trabalhador surge com a reforma psiquiátrica, havendo, inclusive, novas denominações que rompem com os especialismos profissionais, tais como: cuidadores, acompanhantes terapêuticos, técnicos de referência.

O cuidado em saúde mental não pode mais ser reduzido a uma atividade caridosa ou à execução de tarefas, baseada em um conhecimento técnico-científico. Exige, agora, um trabalhador implicado política e afetivamente com a transformação dos modos de cuidar e se relacionar com a loucura, que trabalhe de forma interdisciplinar, em uma articulação da gestão com a clínica, circulando pela cidade, considerando um duplo papel como agenciador do cuidado e da rede, não apenas de saúde, mas também de suporte social, sendo que uma crescente autonomia na gestão do trabalho é diretamente proporcional ao aumento de responsabilidades e compromissos das equipes de trabalho.

A partir dessas considerações genealógicas, compreendemos que o trabalhador de saúde mental circula em um espaço tenso e de disputa entre diferentes formações discursivas, desde a crença de que cuidar é uma forma de caridade (discurso religioso), passando pela afirmação de que é a ciência que pode falar do tratamento dos desvios de comportamento (discurso científico), até o entendimento de que não basta apenas conhecimento técnico-científico, mas também implicação política e afetiva com a construção de um outro modo de se relacionar com a diferença (reforma psiquiátrica). Se estes diferentes discursos e práticas parecem monolíticos e distantes no tempo, como se houvesse uma progressão evolutiva de um para outro, percebe-se que não há uma nítida ruptura entre 
eles, ao contrário, todos coabitam o cotidiano dos atuais serviços de saúde mental, inclusive aqueles destinados ao cuidado de pessoas que usam drogas.

\section{A Política de Saúde Mental no Brasil no contexto do SUS}

Nesta seção, percorreremos rapidamente os principais momentos da constituição da política de saúde mental brasileira, incluindo o momento em que os problemas decorrentes do uso de drogas passam a exigir ações desta política.

A partir da constituição do SUS em 1990 e da concomitante criação da Coordenação Nacional de Saúde Mental, de acordo com Borges e Baptista (2008), temos quatro diferentes momentos na construção do modelo assistencial, que dão o tom da reforma psiquiátrica em curso no país:

1) Momento Germinativo (1990-6): Construção do consenso e legitimidade em torno da política de saúde mental (criação da Coordenação Nacional de Saúde Mental, realização da II Conferência Nacional de Saúde Mental, que em seu relatório final estabeleceu as diretrizes da nova política); início do processo de desospitalização (avaliação dos hospitais psiquiátricos, descredenciamento de leitos "fantasmas"); e abertura do financiamento para serviços extra-hospitalares (Portarias no 189/91 e 224/1992);

2) Momento de Latência (1997-9): A troca dos Ministros de Saúde, levou ao enfraquecimento da Coordenação Nacional, que passou a ter função mais consultiva do que propositiva;

3) Momento de Retomada (2000-1): Criação dos 
Serviços Residenciais Terapêuticos para egressos de longas internações, realização da III Conferência Nacional de Saúde Mental e promulgação da "Lei da Reforma Psiquiátrica" (10.216/01), após 12 anos de tramitação no Congresso Nacional;

4) Momento de Expansão (2002-4): Criação do Programa De Volta pra Casa (auxílio-reabilitação psicossocial para egressos de longas internações), nova regulamentação (Portaria 336/02) e expansão significativa dos Caps, com recursos extra-teto (FAEC).

Acreditamos que permanecemos neste momento de expansão apontado pelas autoras. Seguindo a linha do tempo proposta, poderíamos destacar, ainda, a realização da IV Conferência Nacional de Saúde Mental - Intersetorial, em 2010; a criação da RAPS - Rede de Atenção Psicossocial (BRASIL. Ministério da Saúde, 2011); e a preocupação crescente com o cuidado de usuários de drogas, especialmente de crack, incorporando a questão à nominação da coordenação nacional, que passa a ser designada como Coordenação Nacional de Saúde Mental, Álcool e outras Drogas.

Aqui vale destacar que os usuários de drogas passam a ser alvo da política de saúde mental brasileira apenas em 2002, com a criação dos primeiros Caps ad. Antes deste período, apesar do conhecimento farto e bem documentado a respeito da internação psiquiátrica, sobretudo de usuários de álcool, não havia uma política específica de saúde mental direcionada a esta população. Chama atenção, ainda, que esta política, ainda incipiente, vem sendo construída principalmente através de planos emergenciais, tais como - PEAD - Plano Emergencial de Ampliação do Acesso ao Tratamento e à Prevenção em Álcool e outras Drogas (Portaria do Ministério da Saúde n. 1190/2009), o Plano Crack - Plano Integrado de Enfrentamento ao Crack e outras 
Drogas (Decreto n. 7179/2010) e o Plano Crack: é preciso vencer (2011).

O ano de 2006 marcou a inversão do financiamento público, antes centralizado nos hospitais psiquiátricos, para a rede de atenção comunitária extra-hospitalar. Se no início do redirecionamento da política de saúde mental, 95\% dos recursos eram destinados às internações em hospitais psiquiátricos, em 2006 este percentual foi de 44,8\%, e tem baixado ano após ano. Ao final de 2011,28,8\% dos recursos do SUS eram destinados aos hospitais psiquiátricos, enquanto $71,2 \%$ dos recursos foram direcionados para serviços extra-hospitalares (BRASIL. Ministério da Saúde, 2012). Chamamos atenção para este fato porque a forma e prioridade de financiamento foram fundamentais para a consolidação dos CAPS como o principal dispositivo da RAPS, passando de 424 serviços, ao final de 2001, para 1742 em dezembro de 2011, aumentando de $21 \%$ para $72 \%$ a cobertura populacional em saúde mental no país. ${ }^{4}$ (BRASIL. Ministério da Saúde, 2012)

Se destacarmos deste montante, apenas os dispositivos para o cuidado de usuários de crack, álcool e outras drogas, os números são bem mais tímidos. Do total dos Caps, pouco mais de $15 \%$ são destinados a esta população, sendo 272 Caps ad e 5 Caps ad III. Percebe-se, ainda, que os incentivos dos distintos planos emergenciais não foram suficientes para ampliar a rede de Caps ad, conforme podemos observar no Gráfico 1.

4 O critério pactuado e utilizado pelo Ministério da Saúde é de 1 Caps/100.000 hab. 


\section{Gráfico 1:}

Comparativo entre o crescimento dos Caps X Caps ad

\section{CRESCIMENTO DOS CAPS X CAPS ad}

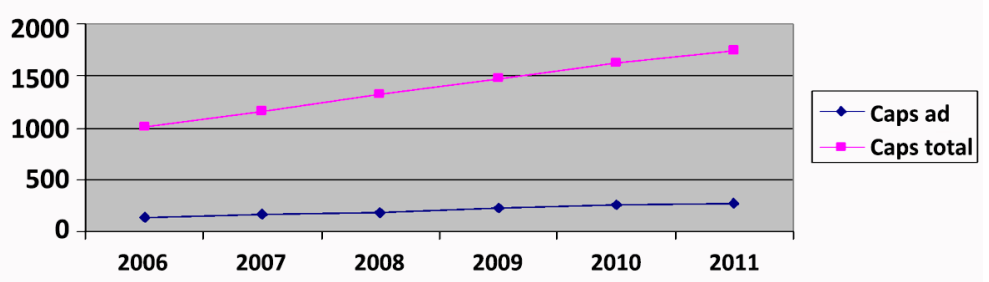

Fonte: BRASIL. Ministério da Saúde, 2012.

\section{Novos Desafios}

Podemos dizer que a reforma psiquiátrica é um processo complexo no qual se articulam quatro dimensões simultâneas: a dimensão epistemológica que diz respeito a uma reconstrução teórica nas áreas da saúde mental e da psiquiatria; a dimensão da assistência, que chama à invenção de novos dispositivos de cuidado; a dimensão jurídico-política com a revisão da legislação civil, penal e sanitária, abrangendo e garantindo direitos civis, sociais e humanos; e, finalmente, a dimensão cultural que inclui um conjunto mais amplo de iniciativas para a transformação do imaginário social sobre a loucura e, por que não também incluir, sobre as formas de uso de drogas. (AMARANTE, 1997)

No entanto, não há unanimidade sobre como deve ser este processo nem sobre o que deve ser priorizado. Há aqueles que se regozijam com os números, considerando que a reforma psiquiátrica efetiva-se com a ampliação 
da rede de Caps, abertura de leitos em hospitais gerais e fechamento de leitos em hospitais psiquiátricos. Para outros, estes indicadores só são válidos se acompanhados da mudança da lógica manicomial, o que implica em problematizar as práticas que interditam e normalizam a vida, seja pelo confinamento ou pela utopia asséptica de uma sociedade homogênea. Há ainda os que questionam o próprio modelo adotado no Brasil, afirmando o perigo de uma "CAPSização" ou "enCAPSulamento" da saúde mental, já que o sofrimento psíquico segue identificado com um serviço protegido e especializado, reduzindo a reforma psiquiátrica a uma reorganização administrativa e tecnocrática de serviços. Finalmente, há aqueles que acreditam que não há reforma sem o acesso à plena cidadania, o protagonismo dos usuários e a mudança do imaginário social sobre a loucura e a radicalidade da diferença.

Além disso, a reforma psiquiátrica elegeu, inicialmente, como prioridade e de forma estratégica, o cuidado de pessoas egressas de longos anos de internação psiquiátrica. Após 25 anos, o perfil da população atendida vem se transformando e diversificando: usuários que nunca tiveram que vivenciar internações, pessoas que buscam apenas a medicação psiquiátrica, crianças, adolescentes e usuários de drogas.

Em meio às problematizações colocadas pelas reformas sanitária e psiquiátrica, como podemos pensar sobre este mais novo desafio, colocado aos trabalhadores de saúde mental, que diz respeito ao cuidado de pessoas que fazem uso prejudicial de drogas? Poderíamos começar com o questionamento sobre as categorias de normal, anormal e patológico, demonstrando o quanto esses conceitos estão encharcados de valores morais. Ou ainda: o que é uso prejudicial de drogas? Quando o uso de drogas 
torna-se um problema em que a saúde deve intervir? Será que equipamentos que foram pensados, originalmente, para atender transtornos mentais graves podem ter seu modelo multiplicado para o atendimento de usuários de drogas?

\section{Referências}

AMARANTE, P. A clínica e a Reforma Psiquiátrica. In: (org.) Archivos de Saúde Mental e Atenção psicossocial 1. Rio de Janeiro: Nau, 2003.

BIRMAN, J. A Physis da Saúde Coletiva. Physis: Revista de Saúde Coletiva, v. 15, p. 11-16, 2005.

; COSTA, J.F. Organização de instituições para uma psiquiatria comunitária. In: AMARANTE, P. (Org.). Psiquiatria social e reforma psiquiátrica. Rio de Janeiro: Fiocruz, 1994. p. 41-72.

BORGES, C. F.; BAPTISTA, T.W.F. O modelo assistencial em saúde mental no Brasil: a trajetória da construção política de 1990 a 2004. Cadernos de Saúde Pública, v. 24, n. 2, p. 456-468, 2008.

BRASIL. Ministério da Saúde. Portaria 189/91. Brasília: MS, 1991.

. Ministério da Saúde. Portaria 224/92. Brasília: MS, 1992.

2002.

. Ministério da Saúde. Portaria 336/02. Brasília: MS,

. Ministério da Saúde. Portaria 1190/09. Brasília: MS, 2009. 
MS, 2011.

Ministério da Saúde. Portaria 3088/11. Brasília:

. Presidência da República. Lei 10216/01. Brasíia: Casa Civil, 2001.

- Presidência da República. Decreto 7179/2010. Brasília: Casa Civil, 2010.

- Saúde Mental em Dados - 10. Informativo eletrônico, Brasília, 2012.

CASTEL, R. A ordem psiquiátrica: a idade de ouro do alienismo. Rio de Janeiro: Graal, 1978.

FOUCAULT, M. História da loucura. São Paulo: Perspectiva, 1999b.

. O nascimento da medicina social. In: MACHADO, R. (org) Microfísica do poder. Rio de Janeiro: Graal, 1999a. p. 79-98.

LUZ, M.T. Notas sobre as políticas de saúde no Brasil de "Transição Democrática - anos 80. Physis; Revista de Saúde Coletiva, v. 1, n.1, p. 76-96, 1991.

MACHADO, R. Danação da norma: medicina social e constituição da psiquiatria no Brasil. Rio de Janeiro: Graal, 1978.

MATTA, Gustavo Correa. Princípios e Diretrizes do Sistema Único de Saúde. Matta, G.C.; Pontes, A.L.M. (orgs) Políticas de saúde: organização e operacionalização do Sistema Único de Saúde. Rio de Janeiro: EPJV/Fiocruz, 2007. Disponível em: <http://www.epsjv.fiocruz.br/index. php?Area $=$ Material\&MNU $=\& T i p o=8 \& N u m=25>$. Acesso em: 11 nov /2014.

PAIM, J. S. O que é o SUS. Rio de Janeiro: Fiocruz, 2011.

PESSOTTI, I. O século dos manicômios. Rio de Janeiro: Ed. 34, 1996. 
Mais substâncias para o trabalho em saúde com usuários de drogas

WADI, Y.M. Palácio para guardar doidos: uma história das lutas pela construção do hospital de alienados e da psiquiatria no Rio Grande do Sul. Porto Alegre: UFRGS, 2002. 



\section{Da Punição ao Tratamento: rupturas e continuidades na abordagem do uso de drogas}

Claudia Ciribelli Rodrigues Silva

\section{Introdução}

Nos últimos anos, estamos assistindo ao aumento do debate em torno da descriminalização e legalização de substâncias cujo consumo é hoje, conforme a legislação penal vigente, ilegal. $O$ crescimento desse debate se sustenta a partir da constatação da falência do modelo de "guerra às drogas" e na tentativa de construção de um novo modelo de enfrentamento da questão. $O$ debate no Brasil é fomentado por experiências de reconstrução da política sobre drogas de outros países, como Portugal e, mais recentemente, o Uruguai. $O$ debate extrapola os meios acadêmicos e técnicos (policial, sanitário, jurídico, etc.) e habita os meios de comunicação de massa e as rodas informais de conversa. Seja para apoiar ou para desqualificar as propostas de alteração da legislação penal, inclusive já materializadas em alguns projetos de lei, é notório que a mobilização social sobre a questão vem crescendo a cada dia. Boa parte daqueles que defendem a descriminalização ou a legalização o fazem apoiando-se no argumento de que se trata de uma questão de saúde, e não de polícia. Entretanto, a pergunta que direciona o presente trabalho 
é: passar o uso de droga do campo jurídico-penal para o campo sanitário representa, efetivamente, uma ruptura como o modelo repressivo?

\section{Da Punição ao Tratamento}

O modelo conhecido como "guerra às drogas", construído nos Estados Unidos nas décadas de setenta e oitenta do século XX, baseava-se em medidas policialescas de forte repressão ao tráfico e ao consumo. Este modelo inspirou a postura adotada em diversos países, dentre eles o Brasil, que se encontrava em período de ditadura militar. Várias convenções internacionais foram realizadas ao longo das décadas de sessenta e setenta e incorporadas no Brasil através de decretos, o que demonstra a dimensão transnacional da questão. Dessa forma, o assunto era analisado e as decisões tomadas sem referências às particularidades tanto das substâncias quanto das populações que as consumiam. Também a mídia atuava na propagação de um discurso de pânico, produzindo um discurso homogêneo sobre o problema, desconsiderando as diferenças entre as substâncias e entre os grupos sociais. (DEL OLMO, 1990) Tratava-se de um problema global cujo modelo de enfrentamento era consenso: a guerra.

É importante ressaltar que esse modelo surge-dentre outros fatores - como resposta ao aumento do consumo de substâncias, principalmente entre os jovens, relacionado com os movimentos de vanguarda e contracultura. Nas décadas de sessenta e setenta, construiu-se uma visão positiva acerca do uso de substâncias psicoativas, com destaque para os alucinógenos. A droga era usada como uma "via de acesso para um mundo novo a ser descoberto 
e construído" (BIRMAN, 1999, p. 238), e o consumo estava relacionado com a possibilidade de novas experimentações. ${ }^{1}$

Batista (1997) chama de "modelo bélico" essa configuração da política sobre drogas no Brasil a partir de 1964, apoiada no significante "guerra". Equiparou-se a penalidade para consumidor e traficante ${ }^{2}$, apesar da tendência em outros países já ser a diferenciação entre eles. Nesses países, aos usuários aplicava-se o "estereótipo do dependente", visto como um doente que deveria receber tratamento adequado, enquanto aos traficantes aplicava-se o "estereótipo do criminoso", os quais deveriam ser encaminhados para o sistema penal tradicional. (DEL OLMO, 1990)

No Brasil essa diferenciação ocorreu apenas na década de setenta, quando a legislação passou a permitir que aqueles que fossem considerados, através de perícia psiquiátrica, usuários patológicos (viciados), pudessem ser encaminhados para tratamento médico, e não mais para a prisão. ${ }^{3} \mathrm{Na}$ prática, essa diferenciação serviu mais para separar os indivíduos de camadas mais pobres daqueles de camadas mais abastadas do que propriamente usuários e traficantes, já que o consumo - em especial de cocaína - crescia entre os jovens de classe média e também o

10 autor identifica a perda do potencial simbólico do uso de droga no final da década de setenta, época em que ela foi tomada pelo narcotráfico e que a questão se transformou em um problema político internacional. A partir de então o uso de droga teria deixado de ter uma positividade, de trazer uma possibilidade construtiva, perdendo seu potencial metafórico para funcionar apenas como a supressão do crescente mal-estar gerado pela queda dos sistemas simbólicos que garantiam aos indivíduos amparo, conforto e sentido. (BIRMAN, 1999)

2 BRASIL. Decreto-lei no 385, de 26 de dezembro de 1968. Dá nova redação ao artigo 281 do Código Penal.

3 BRASIL. Lei no 5.726, de 29 de outubro de 1971. Dispõe sobre medidas preventivas e repressivas ao tráfico e uso de substâncias entorpecentes ou que determinem dependência física ou psíquica e dá outras providências. 
envolvimento dos jovens da periferia com sua distribuição na cidade. Portanto, era preciso impedir que os jovens de classes mais altas tivessem o mesmo destino que os mais pobres: a prisão. Poucos anos depois, diferenciou-se a penalidade para tráfico e consumo de substâncias ilegais (elevou-se a penalidade para o tráfico para 15 anos de reclusão enquanto para o consumo fixou-se a pena em 2 anos de detenção) ${ }^{4,5}$.

Em resumo, ao longo da década de setenta, estabeleceram-se três estatutos diferenciados: traficantes, dependentes e usuários. Os traficantes eram direcionados ao sistema penal com penas cada vez maiores; os dependentes - com a devida avaliação de um psiquiatra - eram encaminhados para tratamento; e os usuários, também eram direcionados ao sistema penal, porém com sanções mais leves que os traficantes. Como afirma Del Olmo (1990), a diferenciação era feita principalmente a partir da caracterização de quem a consumia:

Se eram os habitantes das favelas, seguramente haviam cometido um delito, porque a maconha os tornava agressivos. Se eram os "meninos de bem", a droga os tornava apáticos. Daí que aos habitantes das favelas fosse aplicado o estereótipo criminoso e fossem condenados a severas penas de prisão por traficância, apesar de só levarem consigo um par de cigarros; em troca, os "meninos de bem", que cultivavam a planta em sua própria casa, como aconteceu em inúmeras ocasiões, eram mandados a alguma

4 BRASIL. Lei no 6.368, de 21 de outubro de 1976. Dispõe sobre medidas de prevenção e repressão ao tráfico ilícito e uso indevido de substâncias entorpecentes ou que determinem dependência física ou psíquica, e dá outras providências.

5 Nas penas de detenção não há o regime fechado, apenas nas penas de reclusão. 
clínica particular para em seguida serem enviados aos Estados Unidos porque eram "doentes" e seriam sujeitos a tratamento, de acordo com o discurso médico tão em moda na época nos Estados Unidos. A eles corresponderia o estereótipo da dependência. (DEL OLMO, 1990, p. 47)

A intervenção sobre os usuários, pelo sistema penal ou médico, justificava-se na visão do usuário como um perigo potencial, capaz de cometer delitos e atos violentos sob efeito da droga e para obtê-la. Questões como a voluntariedade do tratamento e a difícil diferenciação entre usuário e dependente (e mesmo entre usuário, dependente e traficante) eram ignoradas em nome da necessidade de conter esse risco virtual.

Esse esforço pela diferenciação entre traficante e usuário e a delimitação de destinos diversos exigia um aparato institucional que o Brasil até então não dispunha. Dessa forma, apenas na década de oitenta o país começou a se estruturar com estabelecimentos para tratamento daqueles considerados dependentes de substâncias psicoativas. Alguns centros de tratamento foram criados, muitos dos quais vinculados às universidades públicas. Entretanto, a expansão desses serviços não acompanhou a crescente demanda. Com isso, houve uma proliferação de instituições do tipo comunidades terapêuticas, estabelecimentos privados e, em sua maioria, vinculados a comunidades religiosas, que passavam a funcionar em parceria com Ministério da Justiça, mesmo não havendo, até o ano de 2001, nenhuma regulamentação formal sobre o funcionamento daquele tipo de instituição. (MACHADO; MIRANDA, 2007) Até aquele momento, as esferas da saúde não estavam envolvidas e mesmo as medidas sanitárias eram propostas no âmbito da Justiça. 
No início do século XXI, verifica-se uma importante ruptura. Se a repressão era a principal estratégia do modelo bélico de combate ao uso de droga, naquele momento começava-se a dar mais ênfase para as "estratégias de cuidado" - como prevenção, tratamento, redução de danos, reinserção social, etc. ${ }^{6}$ O Ministério da Saúde, que não figurava entre as instâncias deliberativas e executivas da política, teve suas competências declaradas ${ }^{7}$ e, no ano de 2003, publicou a "Política do Ministério da Saúde para a atenção integral a usuários de álcool e outras drogas" ${ }^{8}$. Essa política representa a tomada da questão pelo movimento de reforma psiquiátrica que direcionava o rearranjo da assistência em saúde mental no Brasil.

Esse movimento, em seu percurso inicial, não havia se ocupado do tratamento de usuários de substâncias psicoativas, como podemos perceber pela ausência de referências ao assunto nos relatórios das primeira e segunda conferência nacionais de saúde mental. Foi apenas na terceira conferência, realizada no ano de 2001, que a questão foi colocada e assumida como pertencente à saúde mental. Mais do que uma discussão técnica, política ou meramente burocrática, essa "tomada" da questão pelo campo da saúde mental representava uma crítica e a resistência ao modelo de assistência baseado

6 Tal ruptura fica evidente se compararmos o Programa Nacional Antidrogas, de 1996, com a Política Nacional Antidrogas, de 2002. Esta última passou a se chamar Política Nacional sobre Drogas no ano de 2005, o que também aponta para a opção por uma caracterização menos combativa através da supressão do prefixo "anti".

7 BRASIL. Lei $n^{\circ} 10.409$, de 11 de janeiro de 2002. Dispõe sobre a prevenção, o tratamento, a fiscalização, o controle e a repressão à produção, ao uso e ao tráfico ilícitos de produtos, substâncias ou drogas ilícitas que causem dependência física ou psíquica, assim elencados pelo Ministério da Saúde, e dá outras providências.

8 BRASIL. Ministério da Saúde. Secretaria Executiva. Coordenação Nacional de DST/Aids. A Política do Ministério da Saúde para atenção integral a usuários de álcool e outras drogas. Brasília: Ministério da Saúde, 2003. 
na internação em instituições de caráter total ${ }^{9}$ e na busca pela abstinência, apresentando como contraponto a proposta de um modelo assistencial conforme os princípios da luta antimanicomial e do Sistema Único de Saúde. Isso significa que princípios como o respeito à singularidade, o protagonismo do sujeito em seu tratamento, o esforço na construção de um cuidado de base comunitária, dentre outros já familiares no tratamento dos demais transtornos mentais, deveriam direcionar também o cuidado ao usuário de álcool e outras drogas. Podemos considerar a criação e instalação dos Centros de Atenção Psicossocial - álcool e outras drogas ${ }^{10}$, ao longo da primeira década do século XXI, como a materialização da inserção do tratamento de usuários de substâncias psicoativas no campo da saúde mental, replicando nessa área um modelo institucional de cuidado construído para os demais transtornos mentais e que vinha se mostrando uma alternativa interessante ao modelo hospitalocêntrico.

Essa inserção representava uma ruptura tanto com o modelo predominantemente jurídico de abordagem da questão, quanto com o próprio modelo da abordagem sanitária. Tal Política do Ministério da Saúde apontava, ainda, que do ponto de vista da saúde pública, o proibicionismo seria uma barreira ao acesso, participação e organização dos usuários. Cabe lembrar que, desde que as instâncias médicas, ou mais especificamente, as instâncias psiquiátricas, passaram a compartilhar com as instâncias jurídicas a responsabilidade - ou, poderíamos dizer também, o poder - de tratar do uso de droga no Brasil,

9 O conceito de instituição total de Goffman $(1996$, p.11) se refere a "um local de residência e trabalho onde um grande número de indivíduos com situação semelhante, separados da sociedade mais ampla por considerável período de tempo, levam uma vida fechada e formalmente administrada".

10 BRASIL. Ministério da Saúde. Portaria n 336, de 19 de Fevereiro de 2002. 
no início do século $X X$, tanto o discurso como as medidas foram marcadamente de cunho higienista, repressivo e segregativo. (SILVA, 2013)

Aos poucos, tornava-se consenso o entendimento de que o uso de droga deveria ser tratado na esfera sanitária e não na esfera jurídica. Nesse sentido, a chamada "nova lei de tóxicos"11 de 2006 corrobora essa tendência. ${ }^{12} \mathrm{~A}$ lei, ainda em vigor, extingue as penas privativas de liberdade para quem "adquirir, guardar, tiver em depósito, transportar ou trouxer consigo, para consumo pessoal ${ }^{13}$, drogas sem autorização ou em desacordo com a determinação legal ou regulamentar". Assim, pretendia-se finalmente efetuar a distinção entre usuário (dependente ou não) e traficante. Por outro lado, a diferenciação entre usuário e dependente ficava obscurecida. Carvalho (2007) entende que:

[...] a Lei no $11.343 / 06$ nivela a importância
dos tratamentos penais entre usuários
e traficantes, criando dois estatutos
autônomos com respostas punitivas
de natureza distinta: alta repressão ao
traficante de drogas, com imposição de
severo regime de punibilidade (penas
privativas de liberdade fixadas entre 05
e 15 anos); e patologização do usuário e

11 BRASIL. Lei $n^{\circ} 11.343$, de 23 de agosto de 2006. Institui o Sistema Nacional de Políticas Públicas sobre Drogas - Sisnad; prescreve medidas para prevenção do uso indevido, atenção e reinserção social de usuários e dependentes de drogas; estabelece normas para repressão à produção não autorizada e ao tráfico ilícito de drogas; define crimes e dá outras providências.

12 Alguns autores como Karam (2008) e Carvalho (2007) questionam a denominação da lei como "nova", já que apesar de propor penas não privativas de liberdade, ainda preserva sanções de caráter penal. Ainda, desde a promulgação da lei 9.099/1995, as infrações penais de menor potencial ofensivo (com penas de seis meses a dois anos, como era o caso do uso de substância psicoativa) deveriam ser objeto dos Juizados Especiais, os quais trabalham exclusivamente com penas não privativas de liberdade.

13 Grifo meu. 
do dependente com aplicação de penas e medidas. (CARVALHO, 2007, p. 72)

Propõe-se que a diferenciação entre consumidor e traficante, a ser feita pelo juiz, baseie-se na natureza e quantidade da substância apreendida, no local e nas condições de apreensão, as circunstâncias sociais, pessoais, além da conduta e dos antecedentes do agente. Tratandose de critérios pouco objetivos, a legislação permite que os indivíduos oriundos de camadas socioeconômicas menos favorecidas tendam a ser considerados traficantes, enquanto aqueles pertencentes às classes mais favorecidas sejam considerados usuários, já que a transposição entre pobreza e criminalidade está bastante presente no nosso imaginário social. Assim, podemos concluir que a "nova lei de tóxicos", apesar de não retirar o consumo de droga do campo penal e de ter a isonomia de sua aplicação questionada, caminha no sentido da amenização da repressão, garantindo ainda o respeito às diretrizes do Ministério da Saúde.

\section{O Continuum Punição-Tratamento}

Os anos que se seguem a essa lei são marcados pela emergência de um discurso de pânico em torno do consumo de crack no país, sob alegação de se tratar de uma "epidemia", mesmo na ausência de dados epidemiológicos que corroborassem essa afirmação ${ }^{14}$, e com afirmações sobre a rápida instalação do vício, sua alta letalidade e a associação com condutas criminosas. A mídia teve importante e decisiva participação na construção e

14 Por esse motivo, o termo "epidemia" será sempre utilizado entre aspas, entendendo que o uso do mesmo produziu efeitos independentemente de sua veracidade ou adequabilidade. 
propagação desse discurso, que ia muito além do debate técnico e político e aos poucos passava a habitar o cotidiano de toda a sociedade.

Como resposta à chamada "epidemia", foi instituído em 2010 o Plano Integrado de Enfrentamento ao Crack e outras drogas ${ }^{15}$, gerido inicialmente pelo Gabinete de Segurança Institucional da Presidência da República e, posteriormente, pelo Ministério da Justiça. ${ }^{16 \text { e } 17} \mathrm{O}$ Plano não trazia modificações na abordagem sobre o assunto, mas buscava garantir a execução imediata das ações já previstas nas políticas existentes. No ano seguinte, foi lançado o programa "Crack, é possível vencer", com investimento para viabilizar a melhoria da rede de assistência nos eixos autoridade, prevenção e cuidado. Estas medidas são exemplos de tentativas de responder à urgência imposta pela "epidemia do crack".

A partir de então, se o tratamento dado no campo sanitário, especialmente a partir de sua aproximação com o movimento de reforma psiquiátrica, vinha caminhando no sentido da construção de um modelo de cuidado não repressivo, não excludente, não moralista, seguindo a

15 BRASIL. Decreto n 7.179, de 20 de maio de 2010. Institui o Plano Integrado de Enfrentamento ao Crack e outras Drogas, cria o seu Comitê Gestor, e dá outras providências.

16 BRASIL. Decreto $n^{\circ} 7.637$, de 8 de dezembro de 2011. Altera o Decreto no 7.179, de 20 de maio de 2010, que institui o Plano Integrado de Enfrentamento ao Crack e outras Drogas.

17 A transferência foi consequência da transferência da Secretaria Nacional de Políticas sobre Drogas (SENAD), do Conselho Nacional de Políticas sobre Drogas (CONAD) e da gestão do Fundo Nacional Antidrogas (FUNAD) do Gabinete de Segurança Institucional da Presidência da República para o Ministério da Justiça. (BRASIL. Decreto ${ }^{\circ} 7.426$, de 7 de janeiro de 2011. Dispõe sobre a transferência da Secretaria Nacional de Políticas sobre Drogas, do Conselho Nacional de Políticas sobre Drogas - CONAD e da gestão do Fundo Nacional Antidrogas - FUNAD do Gabinete de Segurança Institucional da Presidência da República para o Ministério da Justiça, bem como sobre remanejamento de cargos para a Defensoria Pública da União) 
perspectiva da redução de danos e do respeito à autonomia do sujeito, o que verificamos a partir da configuração da "epidemia do crack" é o risco eminente de um retrocesso nesse percurso. Um fato curioso para nos ajudar a entender esse momento foi quando, no lançamento do Plano, cogitou-se que o dispositivo conhecido como Consultório de Rua ${ }^{18}$ realizasse internações de caráter compulsório. Essa postura foi defendida pelo ministro da saúde, enquanto - ministro da justiça manifestou-se contrariamente à medida. ${ }^{19} \mathrm{~A}$ proposta gerou grande polêmica e acabou por ser suprimida, mas deixou claro como foi o campo da saúde, e não mais da justiça, que passava a defender modalidades de tratamento baseada na segregação e na coerção, ainda que pelo viés do tratamento e não da pena.

A sensação de medo produzida pela "epidemia do crack" e pela visão do usuário como um sujeito perigoso, capaz de cometer delitos e atos violentos em nome de seu vício e por efeito da substância, sem autocontrole e incapaz de gerir a própria vida, está na base das medidas construídas para seu enfrentamento. Acredita-se ser preciso proteger a sociedade desse perigo e, também, proteger o próprio sujeito de si mesmo. Porém, por ser uma "questão de saúde pública", uma "epidemia", ela deve ser enfrentada no âmbito da saúde. Nesse sentido, a internação, seja ela voluntária, involuntária ou compulsória, ${ }^{20}$ se torna a estratégia central:

180 dispositivo, que oferece atenção à população em situação de rua, no próprio espaço da rua, é hoje denominado Consultório na Rua, estando vinculado não mais à saúde mental, mas à atenção básica.

19 MOURA, Rafael Moraes; MONTEIRO, Tânia. Pacote do governo prevê internação involuntária de usuários de crack. Disponível em: <http:// www.estadao.com.br/noticias/geral, pacote-do-governo-preve-internacao-involuntaria-de-usuarios-de-crack,807926,0.htm>. Acesso em 20 jun 2012. MARQUES, Luciana. Programa contra crack prevê internação compulsória. Disponível em: <http://veja.abril.com.br/noticia/ brasil/programa-contra-crack-preve-internacao-compulsoria>. Acesso em: 20 jun 2012.

20 Atualmente, segundo a Lei 10.216/2001, são três os tipos de internação: voluntária (com o consentimento do paciente); involuntária (sem o 
ao mesmo tempo em que ela se situa dentro da saúde e tem por argumento o tratamento desses indivíduos, ela responde bem à demanda de segregação desse perigo que circula nas ruas das cidades. É assim que presenciamos, nos últimos anos, a internação como estratégia privilegiada também nas políticas públicas, tanto em campanhas de abordagem e recolhimento compulsório (no Rio de Janeiro e São Paulo, principalmente) quanto no financiamento dessa modalidade de tratamento, através das comunidades terapêuticas. Cabe ressaltar que o recolhimento (termo amplamente utilizado no momento) e encaminhamento para as comunidades terapêuticas foi efetuado principalmente através dos dispositivos da assistência social. De maneira geral, essas medidas contam com amplo consentimento e apoio popular ${ }^{21}$, apesar de serem criticadas por alguns setores que denunciam a ilegalidade, o caráter higienista e a baixa eficácia dessa política ${ }^{22}$. Certamente a internação não é a única estratégia utilizada, e não se deve desconsiderar a existência de outros dispositivos propostos pelo paradigma antimanicomial. Contudo, é evidente o lugar privilegiado dado à internação (seja em hospitais ou comunidades terapêuticas, voluntárias, involuntárias ou compulsórias), que chega a colocá-la como sinônimo de tratamento.

Por outro lado, também nos últimos anos, vivemos um movimento em outro sentido: o debate sobre a descriminalização e legalização do consumo de droga acelerou-se e parece vir ganhando cada vez mais adeptos,

consentimento do paciente, a pedido de terceiros); e compulsória (sem o consentimento do paciente, determinada por um juiz). No caso das duas últimas, há acompanhamento pelo Ministério Público. Em todos os casos, contudo, é necessária a avaliação de um médico.

21 MARINHEIRO, Vaguinaldo. 90\% aprovam internação involuntária. Folha de São Paulo, São Paulo, 25 jan. 2012. Cotidiano, p. 1.

22 CASTRO, Carolina; LIMA, Ludmilla de. Crack: internação compulsória de adultos divide opiniões. O Globo, Rio de Janeiro, 22 out. 2012. Disponível em: <http://oglobo.globo.com/rio/crack-internacao-compulsoria-de-adultos-divide-opinioes-6487379>. Acesso em: 23 out 2012. 
principalmente após a experiência de legalização em curso no Uruguai. Certamente, há nuances nesse debate. Alguns defendem apenas a descriminalização, ou seja, a retirada de qualquer sanção penal para o usuário, mantendo-se a repressão para a produção e comércio, enquanto outros defendem a plena legalização, com regulaçãogovernamental do processo de produção e comércio. Alguns defendem a descriminalização ou legalização apenas da maconha, enquanto outros acreditam que todas as substâncias deveriam estar incluídas no projeto. Porém, o que aparece como consenso, acima de todas essas divergências, é o entendimento de que o consumo de droga é uma questão de saúde, e por isso as medidas penais devem ser extintas.

Podemos constatar, assim, que apesar do esforço para diferenciar o usuário do traficante e tratá-lo segundo medidas de saúde não repressivas, o momento atual evidencia como as medidas sanitárias podem ser tão repressivas quanto as medidas punitivas do sistema penal. O discurso construído sobre o crack toma o problema como uma epidemia, associada a uma conduta violenta e criminosa. As "cracolândias" espalhadas pelo país são vistas como terras sem lei habitadas por pessoas sem qualquer resquício de humanidade: não tem nome, rosto, nem história. São aglomerados de corpos que colocam suas mazelas para serem vistas a olhos nus. Diante do insuportável dessa questão, a resposta tem sido o retorno das práticas de segregação através da internação. O deslocamento do usuário de droga da esfera jurídica para o âmbito da saúde pública, aqui analisado genealogicamente, permite, inclusive, uma retirada ainda maior da Justiça dessa questão, pela via da descriminalização/legalização. Porém, as medidas repressivas parecem perpetuar pela "máscara" do tratamento.

Se hoje entendemos como paradoxo termos utilizados no início do século XX para se referir às "penas de 
internação" 23 e os "tratamentos médicos e correcionais"24, isso se deve ao esforço que se fez ao longo do tempo para tentar dissociar o tratamento médico do tratamento penal, o doente do criminoso. Contudo, apesar do esforço discursivo para construir um limite entre esses dois campos, na prática o que se percebe é que suas fronteiras permanecem mal estabelecidas, perpetuando o continuum já apresentado por Foucault (2001) entre o tratamento médico e a instituição judiciária e denunciando a cumplicidade entre eles.

\section{Considerações Finais}

A reflexão aqui realizada buscou chamar atenção para o fato de que a simples passagem do controle sobre o uso de droga do campo jurídico para o campo sanitário, da referência às leis para a referência às normas produzidas pelos saberes da saúde, não garante, a priori, uma transformação radical na abordagem da questão. A ruptura com o modelo repressivo, coercitivo e segregativo depende, mais do que da transferência para outra instituição (da Justiça para a Saúde) ou do formato da abordagem (da prisão para a internação), da construção de uma nova ética. $E$ a construção ou não dessa nova ética na assistência e na política sobre drogas, responsabilidade coletiva da nossa sociedade, poderá determinar ou impedir a reedição do triste, longo e ainda em desconstrução - processo (real e

23 BRASIL. Decreto no 4.294, de 06 de julho de 1921. Estabelece penalidades para os contraventores na venda de cocaína, ópio, morfina e seus derivados; cria um estabelecimento especial para internação dos intoxicados pelo álcool ou substancias venenosas; estabelece as formas de processo e julgamento e manda abrir os créditos necessários.

24 BRASIL. Decreto no 14.969, de 03 de setembro de 1921. Aprova o regulamento para a entrada no país das substancias tóxicas, penalidades impostas aos contraventores e sanatório para toxicômanos. 
simbólico) de enclausuramento da loucura. Se, na leitura de FOUCAULT (1961), a loucura foi herdeira da lepra, devemos estar atentos então para que os usuários de drogas não perpetuem essa história.

\section{Referências}

BATISTA, N. Política criminal com derramamento de sangue. Revista Brasileira de Ciências Criminais, São Paulo, v. 5, n. 5, p. 129-146, out./dez. 1997.

BIRMAN, J. Mal-estar na atualidade: A psicanálise e as novas formas de subjetivação. Rio de Janeiro: Civilização Brasileira, 1999.

BRASIL. Decreto $n^{\circ} \mathbf{4 . 3 4 5}$, de 26 de agosto de 2002. Institui a Política Nacional Antidrogas e dá outras providências.

. Decreto $n^{\circ}$ 7.179, de 20 de maio de 2010. Institui o Plano Integrado de Enfrentamento ao Crack e outras Drogas, cria o seu Comitê Gestor, e dá outras providências.

. Decreto $\mathbf{n}^{\circ} \mathbf{7 . 4 2 6}$, de 7 de janeiro de 2011. Dispõe sobre a transferência da Secretaria Nacional de Políticas sobre Drogas, do Conselho Nacional de Políticas sobre Drogas - CONAD e da gestão do Fundo Nacional Antidrogas - FUNAD do Gabinete de Segurança Institucional da Presidência da República para o Ministério da Justiça, bem como sobre remanejamento de cargos para a Defensoria Pública da União.

. Decreto $\mathrm{n}^{\circ}$ 7.637, de 8 de dezembro de 2011. Altera o Decreto no 7.179, de 20 de maio de 2010, que institui o Plano Integrado de Enfrentamento ao Crack e outras Drogas. 
. Decreto no 14.969, de 03 de setembro de 1921. Aprova o regulamento para a entrada no país das substancias tóxicas, penalidades impostas aos contraventores e sanatório para toxicômanos.

. Decreto no 4.294, de 06 de julho de 1921. Estabelece penalidades para os contraventores na venda de cocaína, ópio, morfina e seus derivados; cria um estabelecimento especial para internação dos intoxicados pelo álcool ou substancias venenosas; estabelece as formas de processo e julgamento e manda abrir os créditos necessários.

. Decreto-lei no 385, de 26 de dezembro de 1968. Dá nova redação ao artigo 281 do Código Penal.

. Lei $n^{\circ} \mathbf{1 0 . 4 0 9}$, de 11 de janeiro de 2002. Dispõe sobre a prevenção, o tratamento, a fiscalização, o controle e a repressão à produção, ao uso e ao tráfico ilícitos de produtos, substâncias ou drogas ilícitas que causem dependência física ou psíquica, assim elencados pelo Ministério da Saúde, e dá outras providências.

. Lei $\mathbf{n}^{\circ} \mathbf{1 1 . 3 4 3}$, de 23 de agosto de 2006. Institui o Sistema Nacional de Políticas Públicas sobre Drogas Sisnad; prescreve medidas para prevenção do uso indevido, atenção e reinserção social de usuários e dependentes de drogas; estabelece normas para repressão à produção não autorizada e ao tráfico ilícito de drogas; define crimes e dá outras providências.

. Lei no 10.216, de 6 de abril de 2001. Dispõe sobre a proteção e os direitos das pessoas portadoras de transtornos mentais e redireciona o modelo assistencial em saúde mental.

. Lei no 5.726, de 29 de outubro de 1971. Dispõe sobre medidas preventivas e repressivas ao tráfico e uso de substâncias entorpecentes ou que determinem dependência física ou psíquica e dá outras providências. 
. Lei no 6.368, de 21 de outubro de 1976. Dispõe sobre medidas de prevenção e repressão ao tráfico ilícito e uso indevido de substâncias entorpecentes ou que determinem dependência física ou psíquica, e dá outras providências.

. Ministério da Justiça. Programa de Ação Nacional Antidrogas. 1996.

. Ministério da Saúde. Portaria $\mathbf{n}^{\circ}$ 336, de 19 de Fevereiro de 2002.

- Ministério da Saúde. Secretaria Executiva. Coordenação Nacional de DST/Aids. A Política do Ministério da Saúde para atenção integral a usuários de álcool e outras drogas. Brasília: Ministério da Saúde, 2003.

CARVALHO, S. A política criminal de drogas no Brasil: estudo criminológico e dogmático. Rio de Janeiro: Lumen Juris, 2007.

CASTRO, Carolina; LIMA, Ludmilla de. Crack: internação compulsória de adultos divide opiniões. O Globo, Rio de Janeiro, 22 out. 2012. Disponível em: <http://oglobo.globo. $\mathrm{com} /$ rio/crack-internacao-compulsoria-de-adultos-divideopinioes-6487379>. Acesso em: 23 out 2012.

DEL OLMO, R. A face oculta da droga. Rio de Janeiro: Revan, 1990.

FOUCAULT, M. Os anormais: curso no Collège de France (1974-1975). São Paulo: Martins Fontes, 2001.

. [1961] História da loucura: na Idade clássica. São Paulo: Perspectiva, 2010.

GOFFMAN, E. Manicômios, prisões e conventos. 5. ed. São Paulo: Perspectiva, 1996.

KARAM, M.L. Lei $11.343 / 06$ e os repetidos danos do proibicionismo. In: VENÂNCIO, R.P.; CARNEIRO, H. (Org.) 
Álcool e drogas na história do Brasil. São Paulo: Alameda, 2008. p. 105-120.

MACHADO, A.R.; MIRANDA, P.S.C. Fragmentos da história da atenção à saúde para usuários de álcool e outras drogas no Brasil: da Justiça à Saúde Pública. História ciência Saúde Manguinhos, Rio de Janeiro, v. 14, n. 3, p. 801-821, jul./set. 2007.

MARINHEIRO, Vaguinaldo. $90 \%$ aprovam internação involuntária. Folha de São Paulo, São Paulo, 25 jan. 2012. Cotidiano, p. 1.

MARQUES, Luciana. Programa contra crack prevê internação compulsória. Veja, 7 dez 2011. Disponível em: <http://veja. abril.com.br/noticia/brasil/programa-contra-crack-preveinternacao-compulsoria>. Acesso em: 20 jun 2012.

MOURA, Rafael Moraes; MONTEIRO, Tânia. Pacote do governo prevê internação involuntária de usuários de crack. Estadão, 7 dez 2011. Disponível em: <http://www. estadao.com.br/noticias/geral, pacote-do-governo-preveinternacao-involuntaria-de-usuarios-de-crack,807926,0. htm>. Acesso em 20 jun 2012.

SILVA, C. C. R. A aliança entre justiça e psiquiatria no controle do uso de droga: medicalização e criminalização na berlinda. Revista Epos, Rio de Janeiro, v. 4, n. 1, jun. 2013. 


\section{Fragmentos da história das drogas e de etnografias com os seus usuários}

Martinho Silva

\section{Introdução}

Com o objetivo de problematizar algumas ideias hegemônicas sobre as drogas e seus usuários, alguns resultados de pesquisas nacionais e internacionais desenvolvidas pelas ciências humanas sobre o tema serão apresentados de modo condensado a seguir. A descrição dos usos do açúcar como medicamento e não só adoçante segundo a perspectiva sócio-histórica de Sidney Mintz, bem como a denúncia da partilha moral entre drogas, medicamentos, alimentos e condimentos e a médico-legal entre usos lícitos ou ilícitos de drogas com base na abordagem genealógica de Eduardo Vargas (2008), são fragmentos da história das drogas que ocupam a primeira parte do texto, contribuindo para um entendimento das mesmas como produtos e não apenas substâncias psicoativas. Na segunda parte do texto as etnografias de Howard Becker (2008 [1963]) com usuários norte-americanos de maconha e de Gilberto Velho (2008 [1998]) com consumidores cariocas de tóxicos como o LSD ganham relevo, mostrando as contingências e contextos dessas carreiras - sequências de mudanças na atitude e na experiência - e favorecendo uma visão crítica sobre a clientela de alguns serviços de saúde. 
Embora hoje o termo drogas seja muitas vezes sinônimo de drogas ilícitas (como a cocaína), principalmente o crack se levarmos em conta a mídia nacional, levandonos a associá-las com algo proibido e prejudicial à saúde, assunto de polícia ou mesmo do setor de saúde pública, nem sempre foi assim. Muito pelo contrário, uma das etimologias do vocábulo drogas remete ao barril de especiarias drogue vate, termo holandês - e a um momento histórico no qual caravelas cruzaram os mares e continentes foram descobertos - inclusive o americano - em busca do sabor do paraíso, o século XIV sendo esse momento no qual viajantes europeus consideraram a pimenta e muitos outros produtos como mercadorias extremamente valiosas. (VARGAS, 2008, p. 42) Além disso, apesar do consumo, produção e distribuição de substancias psicoativas como a maconha - ainda hoje chamada de entorpecente, narcótico ou tóxico em certos contextos institucionais - ser combatido por forças policiais também em nosso país, penalizado embora nem sempre com prisão segundo a mais recente lei nacional, nem todas essas substâncias que alteram a consciência são objeto de repressão. Algumas delas são até mesmo prescritas por médicos, sendo que podemos dizer que somos inclusive incitados a utilizá-las pela indústria farmacêutica, através da mediação de seus representantes comerciais e científicos. (VARGAS, 1998, p. 122) Esse parece ser o caso dos conhecidos 'calmantes', como os ansiolíticos, um deles tendo sido um dos mais consumidos medicamentos do Brasil no ano de 2010: o Rivotril.

Desta maneira, as drogas não são consideradas apenas substâncias nocivas ao corpo e à mente, mas também mercadorias valiosas, seus usuários não sendo apenas reprimidos pela polícia, como também incitados ao consumo pela indústria farmacêutica. Que outras concepções históricas existem sobre as drogas para além da vigente em nosso mundo contemporâneo? O que dizem 
os usuários sobre o uso que fazem dessas substanciasmercadorias?

\section{História das drogas}

As drogas podem ser incluídas entre as mercadorias do consumo material humano (CARNEIRO, 2005), particularmente entre as ingeridas pelo corpo, os remédios ficando no mesmo plano que os alimentos e bebidas desta perspectiva e distinguindo-se do vestuário e do abrigo, estas últimas mercadorias que revestem o corpo. Com base nas contribuições de K. Marx, particularmente sua famosa distinção entre valor de uso e valor de troca (grosso modo, o valor de uso de uma poltrona é o seu conforto, o valor de troca podendo ser alto ou baixo dependendo das relações de produção em jogo), o citado autor considera a droga uma "mercadoria máxima":

Isso não significa que as drogas não possuam um valor de uso de natureza essencial como necessidade humana... mas sim que esse valor de uso é hipertrofiado nas formas extremas de dependência por efeito de sua conversão num valor de troca também maximizado por meio do mecanismo da proibição estatal de alguns destes produtos essenciais. (CARNEIRO, 2005, p. 8)

Em outras palavras, drogas estão estreitamente ligadas a valores, o poder de saciar da substância aumentando na mesma proporção em que o produto aumenta de preço, o estado de dependência articulando-se justamente com a amplitude do proibicionismo, a raridade do produto no mercado estimulando ainda mais as formas prejudiciais de uso. 
Enquanto o foco dos estudos do historiador Henrique Carneiro (2005) está nas bebidas alcoólicas, bem como na denúncia da repressão às drogas (o conhecido proibicionismo), o citado antropólogo Eduardo Vargas (2008) procura justamente denunciar essa "partilha moral" entre drogas, medicamentos, condimentos, alimentos e cosméticos que nos faz estudar com maior frequência a história de substâncias em particular e não das drogas em geral, concluindo em seus estudos históricos que apenas no século XX é que as drogas se tornaram um "problema", embora antes disso tenham sido alvo de "proibição", tornando-se mais recentemente ainda um problema não só de segurança pública como também de saúde pública. (VARGAS, 2008, p. 42;54) Enquanto Carneiro (2005) considera as drogas principalmente como mercadorias cujo consumo é reprimido no mercado, Vargas (1998) as vê como um dispositivo - tanto quanto mercadoria em $\mathrm{K}$. Marx, este também é um conhecido conceito do filósofo $M$. Foucault - que nos incita à valorizar a longevidade (vida em extensão) em detrimento da vida em intensidade.

Entre os séculos XIV e XVI a sociedade ocidental viveu a "loucura pelas especiarias", fazendo com que a busca por produtos como a pimenta viesse a favorecer a emergência de um mundo para além da Europa. Entre os séculos XVII e XIX foi a vez dos "alimentos-droga" entrarem em cena, a produção, distribuição e consumo do açúcar, do café, do chá e do chocolate sendo exemplares dessas substâncias que hoje não são classificadas como drogas mas já foram estimulantes ora rejeitados pela Igreja, ora disponíveis apenas para poucos estratos sociais, ora utilizados cotidianamente pela grande maioria dos cidadãos. Enfim, coma emergência da indústria farmacêutica e dasnormativas internacionais da Organização das Nações Unidas no século $\mathrm{XX}$, classificamos as drogas em lícitas e ilícitas, separamos as drogas dos medicamentos e consideramos os alimentos, os cosméticos e as drogas produtos absolutamente diferentes 
uns dos outros. (VARGAS, 2008) A história das drogas é, portanto, a história da medicalização e criminalização de certas substâncias e principalmente determinados usos das mesmas, o uso medicinal sendo incitado enquanto o recreativo é reprimido, o uso para ter uma vida longa sendo fomentado enquanto aquele para intensificá-la e correr o risco de encurtá-la tendo sido regularmente classificado como nocivo, particularmente pelas autoridades médicas. (VARGAS, 1998) Incitação e impedimento do uso de drogas, particularmente incitação ao uso de fármacos e impedimento do uso de maconha coincidindo do ponto de vista histórico para o autor desta genealogia das drogas, diferenciando-a da maioria dos estudos históricos nacionais, cuja ênfase é mais no proibicionismo, na repressão às drogas.

Vamos nos deter nos ditos "alimentos-droga", particularmente o açúcar. (MINTZ, 1986) O que podemos apreender das considerações de Sidney Mintz sobre esse objeto ora precioso ora mercantilizável, ora bastante exótico, caro e distribuído quase que exclusivamente entre a corte até o século XVII, ora tornado uma necessidade de toda a população, barato e largamente distribuído a partir do século XVII, é que o uso e significado do açúcar estão implicados um no outro. Ao contrário da suposição de que correlaciona de modo universal o açúcar com a doçura, a afeição, a brancura, a pureza, o luxo e a mulher (MINTZ, 1986, p. 140-141), esse autor nos lança rumo a uma longa argumentação acerca dos diferentes usos, em diferentes contextos, por diferentes agentes em variados estratos sociais, em determinadas épocas e sob determinadas condições de produção e consumo do açúcar, produzindo (e facilitando a manipulação e difusão) de diferentes significados. Embora complexo, esse raciocínio desenvolvido pelo autor é necessário quando estamos conversando sobre as drogas entre trabalhadores de saúde, pelo menos por duas razões. 
Em primeiro lugar, incluir o açúcar na história das drogas não é uma maneira de ampliar o conjunto de substâncias que devem ser consideradas drogas e quanto mais drogas ilícitas, apenas uma consequência da denúncia da citada partilha moral. Ou seja, não partimos aqui da definição contemporânea de drogas, ligando-as às ilícitas segundo as convenções da Organização das Nações Unidas (ONU) e associando-as a algo proibido e nocivo, mas do vocábulo drogue vate e seus variados sentidos e usos aos longos dos últimos 8 séculos. Em segundo lugar, o açúcar $e$, como veremos mais adiante, o adoçante, faz parte de nossa dieta diária, bem como do cotidiano das ações e serviços de saúde, na forma da prevenção e tratamento do diabetes, segundo um dos mais importantes historiadores das drogas do país uma das principais causas de mortalidade no México. (CARNEIRO, 2013)

Sidney Mintz nos faz pensar que aquele proletário inglês que estivesse usando açúcar no século XIX não estaria necessariamente copiando o hábito que a corte tinha durante o século XV (MINTZ, 1986, p. 132-133), pois para ele seria fundamental perguntar-se: quem está usando, um homem, uma mulher ou uma criança? Em casa ou no trabalho? Tem o hábito de adoçar o chá ou está a comer uma sobremesa? Em que país? Qual a taxa de exportação e importação do produto? O consumo é alto ou baixo? Enfim, esse autor nos possibilita desssencializar o açúcar e desnaturalizar o sabor doce, mostrando, por exemplo, o quanto o uso do açúcar no chá - no nosso caso, do café principalmente - e o hábito de tomá-lo tem tanto uma ligação com nossas "preferências" e "gostos" mais individuais quanto com mudanças nas relações entre indivíduos e grupos nas metrópoles e colônias.

Procurando compreender as relações entre centro e periferia ou entre colônias e metrópoles - leia-se, entre 
Europa e África / América - de um modo menos unilinear (o acento exclusivo na dominação e exploração - econômica, política, cultural - da Europa sobre o resto do mundo), Mintz pretende demonstrar a interdependência entre as mesmas. A gravura com três mulheres na contra-capa do citado livro é ilustrativa dessa questão, elas representam cada uma um continente e estão abraçadas e apoiando-se uma à outra, com a "branca" ao centro.

Para alcançar um objetivo tão abrangente Sidney Mintz (1986) tem um instrumento: acompanhar o consumo do açúcar na Europa, principalmente Inglaterra, ao longo dos séculos. $O$ autor reúne 5 usos principais do açúcar ao longo da história de sua produção e consumo: medicamento, especiaria (tempero), enfeite (material decorativo), adoçante e conservante. Esses usos não acontecem em evolução contínua mas são sobrepostos ao longo do tempo. (MINTZ, 1986, p. 78) De tempero sofisticado, o açúcar tornou-se principalmente um adoçante. De material decorativo, foi se tornando um conservante (MINTZ, 1986, p. 79). De signo de riqueza, transformou-se em uma necessidade comum. (MINTZ, 1986, p. 80) O autor ainda demonstra que não é por meio de entidades como países que tais relações podem ser investigadas, mas de grupos, estratos, classes, tais como o proletariado e a corte inglesas de um lado e os escravos e mercadores americanos de outro.

Os principais princípios analíticos que podem ser destacados são as dicotomias "significados atribuídos de dentro e de fora ao açúcar" (MINTZ, 1986, p. 151, 167, 171) e "processos de intensificação e extensificação do uso do açúcar." (MINTZ, 1986, p. 122, 152, 167) A ideia geral é a de que os significados atribuídos de dentro de um grupo ao açúcar são aqueles ligados aos rituais e à agenda do mesmo, e portanto corriqueiro, cotidiano, usual. Quando 
um amplo número de pessoas torna-se familiarizado com esse significado do açúcar seu uso torna-se regular - como no caso de adoçar o café ou consumir sobremesas após as refeições - e pode acontecer uma remodelagem dos significados atribuídos a esse objeto no passado ou tradição, de modo que neste caso fala-se de uma extensificação de seu uso, enquanto quando há uma continuidade com o uso tradicional, como no uso do açúcar em ocasiões cerimoniais, em forma de bolo de casamento por exemplo, fala-se de uma intensificação de seu uso.

Também há significados atribuídos de fora do grupo ao açúcar, quando pensamos no lugar da sacarina na história das colônias, do comércio, da intriga política, das políticas públicas e da lei, algo mais possível de ser manipulado e difundido por agrupamentos sociais e ligado ao exercício informal do poder, com capacidade de modelar os significados atribuídos de dentro do grupo ao açúcar.

Mintz (1986) lembra ainda que a relação entre produção e consumo correm em paralelo com a relação entre uso e significado, sendo que para o autor o significado não é intrínseco à substância, mas emerge do seu uso, sendo que há forças que contribuem para aumentar a disponibilidade das substâncias às pessoas, que não podem ser ignoradas. Ele mostra também como o açúcar deixou de ser um produto exótico e ligado ao luxo para se tornar uma necessidade cotidiana, bem como de que maneira o significado atribuído pelos agentes ao açúcar é difundido e seu uso não é distribuído igualmente. 


\section{Etnografias com usuários de drogas}

Howard Becker (2008) mostra como o uso recreativo de maconha não é um costume simples de ser adquirido, enfatizando o papel tanto do aprendizado das técnicas (tragar, o 'tapa') no consumo desta droga quanto do aprendizado das próprias percepções (fome intensa, a 'larica') e mesmo dos gostos (prazer, o 'barato'), de maneira que é um hábito "socialmente adquirido." (BECKER, 2008, p. 62) Para o autor, o uso da maconha costuma ser predominantemente coletivo e mediado pelo grupo de usuários, de modo que é necessário algum grau de socialização para que a prática deixe de ser única e ocasional e passe a acontecer mais vezes e mesmo se tornar frequente, enfatizando "o importante papel da interação com outros usuários na aquisição dos conceitos que tornam essa consciência [dos sintomas para se obter um 'barato'] possível." (BECKER, 2008, p. 59) Em outras palavras, o uso de drogas não depende exclusivamente da substância nem para acontecer nem para se manter.

Com base em 50 entrevistas com usuários norteamericanos de maconha na década de 1950, principalmente músicos conhecidos pelo autor mas também profissionais liberais, operários e mecânicos, ele demonstra que o uso de drogas é não só contextual como também contingente, já que "A mesma pessoa que, num momento, é incapaz de usar a droga por prazer, num estágio posterior será capaz e estará desejosa de fazê-lo e, mais tarde ainda, se tornará de novo incapaz de usá-la dessa maneira." (BECKER, 2008, p. 54) Uma pessoa curiosa com relação à experiência pode nem sequer ter acesso à droga; uma pessoa que tem acesso à droga pode não aprender a técnica que fornece uma dosagem suficiente para que os efeitos da droga se manifestem; uma pessoa ignorante e mesmo temerosa a respeito dos efeitos da droga pode não 
aprender a reconhecer os sintomas do 'barato', ou seja, pode não redefinir as primeiras experiências tipicamente assustadoras em sensações agradáveis, estas duas últimas certamente descontinuando o uso.

Apenas os que aprendem a técnica para usar a maconha, a perceber os efeitos e a gostar deles, têm condições de desejar maconha, são capazes de usar maconha por prazer, a disposição para tanto sendo construída ao longo de um processo e não dada de antemão. (BECKER, 2008, p. 67) Em outras palavras, para Becker um traço psicológico não predispõe - como a necessidade de devanear ou fugir dos conflitos psíquicos - não predispõe ao uso de drogas, pois a motivação para o mesmo só é adquirida após o comportamento, é a posteriori, não a priori. (BECKER, 2008, p. 51)

Embora pesquisas recentes com jovens dinamarqueses em tratamento (JARVINEN; RAVN, 2014) revisem os resultados do estudo de Becker, particularmente a tese segundo a qual uma das condições para o uso de maconha é a mediação de um grupo, este estudo realizado antes mesmo da primeira normativa internacional da ONU sobre o tema das drogas (publicado em 1953, antes de 1961 portanto) inspirou muitos outros acerca do assunto no Brasil, entre eles uma etnografia recente também com usuários de maconha (VARGAS, 2006) e uma etnografia precursora com consumidores de tóxicos (VELHO, 2008), maconha principalmente, mas também LSD, cocaína e mandrix (sedativo).

Enquanto Becker (2008) mostra a impertinência da pergunta dirigida aos usuários de maconha 'Por que fazem isso?', Vargas (2006) aponta a inconsistência desta e de outras perguntas do ponto de vista dos usuários de drogas, como 'Qual o significado do uso de drogas?', propondo que nos aproximemos da perspectiva que os próprios 
usuários têm do consumo destas substâncias e com eles nos perguntemos: 'O que ocorre em práticas como essas?' e também 'Que experiências usuários e substâncias realizam?'. Enquanto Becker (2008) descreve a produção do desejo de usar maconha entre pessoas rotuladas como desviantes, sublinhando a experiência do 'barato', Vargas (2006) destaca a fabricação do evento 'onda' na relação entre usuário e substância, uma modalidade entre outras de (in) (alter) ação, caracterizada por experiências intensivas de auto-abandono, o sair de si mesmo. Bem distante da visão hegemônica - inclusive entre pesquisadores das ciências humanas - que associam tal experiência ao erro, à fraqueza e à falta (defeito físico, falha psicológica, perda dos referenciais simbólicos, desvio moral), oscilando entre as fantasias subjetivas dos usuários e as determinações objetivas da substância, nesse cenário usuariocentrado outras perguntas se colocam: quem controla a onda? A onda ocorre ou não? Há ou não alter-ação? Ou com base nas categorias utilizadas pelos próprios usuários: bateu? Trocou o canal?

Remetendo à produção deliberada de alterações intensivas, cujos resultados são imprevistos embora certamente envolvam entrega e renúncia e não tenham como pressuposto o valor da autonomia, nessa experiência de ultrapassar-se e deixar-se ultrapassar - semelhante à paixão e ao êxtase - é sempre outrem que põe em movimento, bem como é a qualidade das misturas que está em jogo mais do que a questão do controle ou da emancipação. (VARGAS, 2006) Enfim, fica implícita nesta etnografia com usuários de maconha no estado de Minas Gerais o quanto o uso de drogas ilícitas costuma ser coletivo e associada à formação de amizades, enquanto o consumo de drogas lícitas como o álcool colaborem ainda mais para a consolidação de laços de parentesco e o abuso de fármacos esteja muitas vezes ligados a vivências de solidão. 
Já na década de 1970 um estudo com "pessoas que consomem tóxicos" (VELHO, 2008, p. 13), um grupo de habitantes da Zona Sul carioca pertencentes às camadas médias urbanas, demonstrava que o uso de maconha, cocaína e ácido lisérgico não era particularmente mais destrutivo ou maligno que aquele do cigarro, álcool e tranquilizantes, nem mesmo que seu uso era indiscriminado no grupo, já que havia formas internas de controle social e identificação de desviantes. (VELHO, 2008, p. 208)

A etnografia dos encontros de um grupo formado por 25 indivíduos entre os anos de 1972 e 1974, como passeios de fim-de-semana, festas e programas de praia, somado a entrevistas com esses amigos, pessoas de ambos os sexos, grande parte deles casais, todas com formação de nível superior (em geral nas áreas de ciências humanas, embora alguns também fossem engenheiros), trata a questão do uso de drogas como parte de um estilo de vida e visão de mundo, qual seja, a da roda intelectual-artística-boêmia do Rio de Janeiro. (VELHO, 2008) O uso de maconha estava ligado a uma busca da autenticidade e era um elemento integrador do grupo, diferentemente do uso de cocaína, adotado por poucos membros do grupo e suscitando divisões internas no mesmo, desdobrando-se na categorização de alguns desses membros como 'loucos', 'doentes' e até 'viciados.' (VELHO, 2008 , p. 77 - 94) A grande maioria dos membros do grupo também era formada de consumidores dos consultórios dos psicanalistas, uma minoria de consumidores de ácido lisérgico, sendo que em alguns momentos essa busca da autenticidade despertava como questão: ácido ou análise? Dois caminhos vistos como distintos nesta busca, eles posteriormente foram considerados compatíveis dentro do grupo (VELHO, 2008), como muitos outros consumos, entre eles maconha e vinho, bem como cocaína e uísque. De todo modo, o uso de drogas era parte de um estilo de vida sofisticado, um símbolo de prestígio e diferenciação. 


\section{Considerações Finais}

Ainda hoje essas etnografias com usuários de drogas nos fornecem subsídios para reflexões, como quando VELHO $(2008$, p. 65) adota o conceito de communitas de Victor Turner para compreender a permissividade nas festas do grupo, particularmente no que diz respeito à ameaça de dissolução das relações estruturais entre marido e mulher ${ }^{1}$. O mesmo podemos dizer da história das drogas, pois ainda que não tenhamos açúcar em casa, possuímos algum adoçante, algo que remete a esse uso que foi se consolidando ao longo do tempo do açúcar. (MINTZ, 1986) Podemos inclusive compreender em que medida outros usos foram se tornando mais raros no mundo contemporâneo, embora não tenham sido extintos, como o uso do açúcar como medicamento, ainda presente ocasionalmente quando sugerimos que alguém tome água com açúcar para se acalmar... E fica a questão: será que esses diferentes usos, significados e processos valem apenas para o açúcar? Sem falar nas outras questões que podemos vir a produzir nos estudos com usuários de drogas, para além de 'por que fazem isso', aproximando-nos assim da perspectiva que os beneficiários das políticas de saúde mental, álcool e outras drogas desenvolveram dessa experiência.

1 Ver a análise da cracolância como communitas no texto de Ygor Alves, a seguir. 


\section{Referências}

BECKER, H. Tornando-se um usuário de maconha. In: (org.) Outsiders: estudos de sociologia do desvio. Rio de Janeiro: Zahar Editores, 2008 [1963]. p. 51-67.

CARNEIRO, H. Conferência de Abertura no Congresso Internacional sobre Drogas, 2013. Disponível em: http:// blogconvergencia.org/blogconvergencia/? $p=1424$. Acesso em: 29 set 2014.

. Pequena Enciclopédia da História das Drogas e Bebidas. São Paulo: Elsevier, 2005.

JARVINEN, M.; RAVN, S. Cannabis careers revisited: Applying Howard S. Becker's theory to present day cannabis use. Social Science \& Medicine, n. 100, p. 133-140, 2014.

MINTZ, S. Sweetness and Power: the place of sugar in modern history. New York: Viking Penguin, 1986.

VARGAS, E. Os Corpos Intensivos: sobre o estatuto social do consumo de drogas legais e ilegais. In: DUARTE, Luiz Fernando; LEAL, Ondina (orgs.). Doença, sofrimento, perturbação: perspectivas etnográficas. Rio de Janeiro: FIOCRUZ, 1998. p. 121-136.

- Fármacos e outros objetos sócio-técnicos: notas para uma genealogia das drogas. In: LABATE, Beatriz et al. (orgs). Drogas e Cultura: novas perspectivas. Salvador: EDUFBA, 2008. p. 41-63.

. Uso de drogas: a alter-ação como evento. Revista de Antropologia, São Paulo, v. 49, n. 2, p. 581-623, 2006.

VELHO, G. Nobres \& Anjos: um estudo de tóxicos e hierarquia. Rio de Janeiro: Editora FGV, 2008 [1998]. 


\section{A Cracolândia como "Communitas" e o frade craqueiro}

Ygor Alves Introdução

A "communitas"1 espontânea como tratada por Victor Turner (1974) a partir da análise de obras literárias e exemplos históricos será por nós aqui utilizada como recurso analítico para compreender o ambiente proporcionado pelo uso do crack e sua atração sobre os craqueiros em três locais distintos: uma biqueira com fumódromo a céu aberto, a Cracolândia paulistana e uma biqueira com fumódromo em local fechado. O local de uso de crack pode ser visto em Malheiros (2012, 2013) como espaço de socialização no consumo da droga desde sua aquisição, em Sapori, Sena e Silva (2010) aparece como articulado à rede de empreendedores e de "bocas", e pode até figurar, injustamente ao nosso ver, como espaço repleto de personagens abjetos. (RUI, 2012, p. 11) Uma visão mais generalizadora, para além do consumo de crack, poderia conceber os locais de uso de drogas como contextos sociais capazes de prover um ambiente mais ou menos propício ao uso controlado. (ZINBERG, 1984) Finalmente, como em

1 Manteremos a palavra "communitas" entre aspas conforme faz Victor Turner. 
Grund (1983), Fernandez (2007) e Alves (2014), o local de uso seria também um espaço onde a estrutura de vida do usuário teria influência sobre seu padrão de uso.

\section{Duas biqueiras com fumódromo e a Cracolândia}

As análises e conclusões presentes neste trabalho são provenientes de observação participante entre usuários de crack da região central da cidade de São Paulo, mais especificamente nas regiões do Cambuci e nas proximidades da estação da Luz, área também conhecida como Cracolândia. São locais de comércio e uso de substâncias psicoativas tornadas ilícitas, territórios psicotrópicos (FERNANDES; PINTO, 2004), ou seja, interstícios espaciais apartados do cotidiano urbano regido pelos mercados de produtos e serviços legais. Um valor importante nestes locais, por exemplo, é o de preservar os não usuários do impacto provocado pela visão do consumo de crack; para tanto, recorre-se às tecnologias disponíveis na rua a fim de se obter abrigo e intimidade. Um dos locais de comércio e uso de crack por nós pesquisado é uma biqueira, como se chamam os locais de venda de substâncias psicoativas tornadas ilícitas na cidade de São Paulo, com fumódromo a céu aberto. Isto significa haver lá comércio e uso constante do crack. Localiza-se em um beco, travessa da Rua São Paulo e às margens da Avenida Radial Leste, no bairro do Cambuci. O uso de crack no local pode aglutinar mais de uma centena de pessoas e há lá cerca de dez barracos.

O barraco é a principal tecnologia disponível na rua para o abrigo e proteção, sua constituição é tão variada quanto são os materiais disponíveis, habilidade, propósitos e gostos pessoais. Surge, então, um ambiente íntimo, adequado para o uso seguro da droga, livre da vergonha 
de se estar agredindo os valores dos passantes, assim como da radiação $o^{2}$ vinda de fora. $\mathrm{O}$ ambiente externo ao barraco está na verdade amplamente interligado a ele, porque a biqueira com fumódromo a céu aberto é um lugar extremamente agitado, onde a troca recíproca de todo tipo de bem e serviço é constante. $O$ barraco é suficientemente permeável a ponto de possibilitar a requisição de bens e serviços disponíveis no lado externo e ao mesmo tempo acompanhar alguma agitação maior na rua.

O barraco de alguém pode ser limpo e consertado por terceiros, tais serviços entrando no circuito da $t^{2} \operatorname{ta}^{3}$. Não apenas os serviços, mas o próprio barraco pode ser vendido, trocado ou alugado. Ter um barraco em boas condições e muito frequentado é quase sempre garantia de acesso perene à pedra de crack. Sua construção e manutenção estão em consonância com a rua ou baixo de viaduto onde é erguido, sendo que antes do De Braços Abertos (DBA), programa municipal dedicado à oferta de serviços aos usuários de crack, eles eram uma presença constante na Cracolândia.

A Cracolândia é um espaço de uso e comércio intenso. Compreendia, no início de nossa etnografia em fevereiro de 2013, parte da Rua do Triunfo e Rua dos Gusmões, assim como o quadrilátero entre a Alameda Glete, a Avenida Rio Branco, a Avenida Duque de Caxias e a Alameda Cleveland. Neste espaço, entre a Praça Princesa Isabel e a Estação Júlio Prestes estão o Largo Coração de Jesus e a Praça Júlio Prestes.

2 Radiação é o termo usado para designar distúrbios nas proximidades do local de uso. Ao perturbar o usuário de crack, se prejudica a fruição dos efeitos da pedra.

3 A treta é a troca generalizada de bens e serviços em torno do consumo do crack. Água, vestuário, cigarros, bebida alcoólica, itens da parafernália de uso, assim como, serviços do tipo buscar água e limpar o local são constantemente trocados dentro e fora dos barracos. 
A chamada Cracolândia está entre duas importantes áreas de práticas ilícitas na história recente de São Paulo: a antiga zona de prostituição do bairro do Bom Retiro e a Boca do Lixo. Até os anos 1930, a prostituição limitava-se à Rua Timbiras, no limite da Boca do Lixo, do lado oposto à atual Cracolândia; posteriormente, essa área de meretrício foi deslocada pelo poder público para a Rua Aimorés, no Bom Retiro, lá permanecendo até as vésperas das comemorações do quarto centenário da cidade, em 1954. Sua dissolução provocou o deslocamento de prostitutas, cafetões, punguistas e "toxicômanos" para a famosa Boca do Lixo. (JOANIDES, 1978, p. 15) Fica claro o quanto esse espaço é mutável. Contudo, há muito viceja na região uma tradição de práticas delituosas e passíveis de estigmatização. Até a implementação do DBA, apenas a Rua dos Gusmões mantinha fora das proximidades da esquina da Rua Helvétia com Dino Bueno o comércio de crack em pleno movimento, tanto durante o dia quanto no período noturno. Também durante a noite, a Rua do Triunfo era ocupada por usuários nas proximidades do Largo General Osório ${ }^{4}$, sendo que neste local se formava um fluxo.

O fluxo é uma aglomeração humana com dezenas ou mesmo centenas de usuários de crack a depender de diversos fatores, desde climáticos, passando pela repressão policial ao tráfico, até a proximidade ou não dos dias de pagamento. A disponibilidade da droga também é fator importante na construção e localização do fluxo. Ele está onde há droga e vice-versa, o crack é levado para próximo aos usuários e estes, por sua vez, se dirigem para o local com maior disponibilidade de crack. Aparentemente, próximo ao fluxo, ou melhor, dentro dele, os blocos - como são chamadas as pedras de crack para venda - são mais

\footnotetext{
4 A região é repleta de biqueiras e hotéis com quartos disponíveis para curtos períodos e tolerantes com o uso, além de albergues privados com preços de sete a dez reais sendo o leito em quarto compartilhado com direito a armário, banho e café da manhã.
} 
"bem fechados", termo êmico utilizado para se referir as pedras maiores e com embalagens ainda não violadas. Longe do fluxo as pedras disponíveis podem ser frações do bloco original, sem necessariamente ter um preço menor. Dentro e fora dele, pode-se adquirir qualquer fração do bloco até chegar a doses unitárias, ou seja, suficiente para um trago, nome dado à unidade de consumo do crack. Estas frações da pedra original de crack são trocadas - também os mais diversos bens e serviços - dentro do circuito da treta, tornando o fluxo um local de imensa agitação e até abrindo espaço a profissionais da treta, ou indivíduos dedicados a comprar e vender objetos usados e novos dispostos em cima de lonas alojadas sobre do asfalto ${ }^{5}$.

Diferente dos dois locais de uso de crack brevemente descritos acima, a biqueira a céu aberto e a Cracolândia, também nos foi possível realizar nossa pesquisa sobre o uso coletivo do crack em uma biqueira com fumódromo em local fechado. Trata-se de um cômodo construído em terreno murado, juntamente com outros poucos imóveis do mesmo tipo, localizado no bairro paulistano do Cambuci, em frente a um edifício ocupado por sem tetos. Um espaço fora da legalidade, isento dos deveres quanto aos padrões de construção, assim como dos direitos aos serviços de saneamento básico, constituindo-se, portanto, em um lugar intersticial. Nele, mãe e filha habitam e fazem uso de crack. A filha comercializa a pedra e a mãe trabalha como catadora de material reciclável. Muitos amigos circulam pelo local e ali fazem uso do crack, mas uma senhora se

5 A localização do fluxo variava antes da implantação do DBA no decorrer dos meses, semanas e até dentro do mesmo dia. Ele podia se fixar por meses na Rua Dino Bueno, entre as Ruas Helvetia e Glete, para em um único dia migrar para a esquina da Rua Helvetia com Cleveland, ou mesmo ocupar os dois locais. Por vezes ofluxo podia se desdobrar até o Largo General Osório, ou mesmo para a esquina da Rua Glete e Avenida Rio Branco. Após a implementação do DBA, o fluxo passou a ocupar durante o dia, um espaço restrito em frente à sede do programa. No período noturno, ele avança um pouco mais pela Rua Helvétia adentro. 
destaca pela maneira afetuosa como é tratada por todos: ela é carinhosamente chamada de Vó.

A conversa costuma fluir por toda noite, enquanto se fuma e vende pedras. Os cachimbos são constantemente modificados e reparados como é comum em qualquer roda de crack. Chama a atenção o cuidado com o trato do cachimbo de Vó por parte da traficante, aqui chamada de Amélia. Observo-a em seus movimentos precisos, ligeiros, enquanto desmonta e monta chimbós ${ }^{6}$, retira borra, prepara novas doses de pedra para si e para outros, principalmente Vó. Ao reparar o chimbó de Vó, Amélia agia certamente movida por compaixão, porém, seu ato nos suscitava pensar sua habilidade artesanal. Proporcionar o máximo de absorção de fumaça a uma pessoa querida através da manutenção do cachimbo é a dimensão instrumental de sua ação, porém, o pedido de Vó para ter seu Boris logo devolvido e a insistência da artífice em contrariar e ralhar com a pessoa que quer agradar, revela um desejo que poderíamos considerar próximo do "trabalho benfeito por si mesmo" (SENNETT, 2012a, p. 19), do artífice. À compulsão pela pedra acrescentar-se-ia a obsessão pela perfeição? Produtora e usuária do cachimbo, envolta em um ritual voltado à maximização do fruir da pedra com a redução dos demais desejos, Amélia come pouco, não arruma seu barraco além do mínimo necessário à recepção de outros igualmente interessados na absorção da fumaça, bebe quase nada. Coisa nenhuma poderia estar mais longe de alguém entregue à satisfação desmedida dos desejos, nossa "usuária forte" se assemelha a uma asceta como S. Francisco de Assis.

Estas observações acima, a respeito do trabalho

6 Chimbó e Boris são dois termos utilizados para se designar o cachimbo de fumar crack.

7 Termo êmico utilizado para designar usuários de grandes quantidades de crack. 
voluntário feito fraternalmente por Amélia, traficante em uma biqueira em local fechado, assim como das trocas correntes no interior e exterior dos barracos em uma biqueira a céu aberto e na Cracolândia, nos levam a propor uma maneira de pensar o ambiente possibilitado pelo uso do crack, a partir da qual seja possível lançar alguma compreensão a respeito de seu apelo e atração sobre os craqueiros para além da fissura proporcionada pela droga.

\section{A "communitas" em torno do uso do crack}

Christiane Vera Felscherinow, ou simplesmente Christiane F. conta no momento de elaboração deste trabalho com cinquenta e três anos de idade e acaba de publicar seu segundo livro de onde tiramos esta breve citação:

Muitas vezes a causa de tudo isso não era apenas a heroína, mas o contexto social. Em determinado momento, mesmo sem a gente se dar conta, a vida passa a funcionar de tal maneira que nos leva sempre aos mesmos lugares e a repetir os mesmos comportamentos. E não me refiro apenas ao vício, mas também às outras coisas que sistematicamente nos fazem voltar à droga. Comigo, por exemplo, o problema de tudo isso no fundo é que não suporto ficar sozinha. Voltei então aos meus antigos conhecidos do reduto, mesmo que não fossem realmente amigos. Eles tinham o mesmo tipo de ocupação, de problemas e de histórias a contar que eu. Tudo isso propiciava uma rápida aproximação, e a gente tentava chamar isso de amizade. (FELSCHERINOW; VUKOVIC, 2014, p. 153) 
Esta senhora, cujo uso de drogas na juventude a levou a ser a grande ídolo de sua geração - na qual o autor deste trabalho se inclui - percebeu claramente (e não poderia ser diferente visto sua experiência de quarenta anos com as drogas) a importância da atração exercida pelo contexto social na manutenção de certo padrão de uso. Nossa pretensão aqui é ter na ideia de "communitas" uma chave capaz de nos proporcionar meios analíticos para desvendar o fascínio do ambiente sobre o usuário de drogas, particularmente o crack.

As relações sociais dentro de determinado contexto social não devem ser consideradas apenas sob sua forma socioestrutural. Outras modalidades, como a "communitas," servem de base para a constituição de relações sociais entre indivíduos não segmentados em posições sociais, nesta forma de relacionarem-se, os indivíduos podem interagir com autêntica reciprocidade. Marcada pela espontaneidade e imediatidade, a "communitas" opõese ao caráter jurídico/ político da estrutura; malgrado a satisfação oriunda de tal situação, a "communitas" estaria, por razões materiais de sobrevivência do grupo, condenada a ter uma vida curta e, em decorrência disto, as relações entre indivíduos retornariam a relações normatizadas entre "pessoas sociais." (TURNER, 1974, p. 161)

A roda de crack aproxima-se de uma das formas de apresentação da "communitas" conforme classificação de Victor Turner (1974), ou seja, a "communitas" existencial, correspondente aos happenings dos hippies dos anos 1960 e início dos anos 1970 nos EUA. Ela é uma experiência de reciprocidade imprevisível e única. Os hippies buscariam este estado de liminaridade, de estar no limite entre dois estados diferentes de existência, através do uso de drogas empregadas para "expansão do pensamento." (TURNER, 1974 , p. 168) Assim sendo, não apenas as sociedades pré-letradas, mas também as sociedades complexas 
e estruturadas são entrecortadas por momentos de liminaridade espontânea nos "intervalos entre os encargos das posições e condições sociais." (TURNER, 1974, p. 168) Os momentos de lazer e recreação como os shows de rock com suas luzes, som em alto volume e consumo de drogas seriam para Turner oportunidades para se criar uma comunhão de uns com os outros. Um estado de completa reciprocidade e profundamente transformador no qual se poderia ir até o íntimo de cada um e aí encontrar algo de profundamente comunal e compartilhado. Uma existência em êxtase, ou seja, fora das normas e suas posições estruturais. Assim, a "communitas" aparece como uma grande tentação humana, a tentação do gozo dos sentimentos prazerosos proporcionados pela liberação das inclinações pessoais das amarras dos desejos e necessidades do social estruturado ${ }^{8}$.

Um modo particularmente interessante de "communitas" existencial foi a vivida por S. Francisco de Assis e analisada por Turner. Nela, uma determinada concepção de pobreza foi colocada em prática e gerou certas atitudes com relação à propriedade. $O$ ideal de S. Francisco para a convivência com seus frades era o da completa desvinculação com o "sistema comercial do mundo" (TURNER, 1974, p. 175) e com os negócios seculares, voltando-se para a convivência entre os pobres, fracos, doentes e pedintes, até os limites da necessidade. Estes limites eram alcançados pelo deliberado apartamento do mundo comercial, com a vida suprida por recompensas as mais incertas possíveis como as da mendicância. Este seria segundo Turner o modo de vida buscado por certos hippies norte-americanos da virada das décadas de $1960-$ 70 , particularmente aqueles em torno da famosa esquina

8 Haveria na "communitas" algo de mágico, capaz de proporcionar uma sensação de poder ilimitado, balizado apenas pela imposição mínima de limites para salvaguardar a existência; encontrar a relação ótima entre "communitas" libertadora e estrutura supridora constituiria o grande desafio dos envolvidos neste tipo de empreitada. 
de Haight-Ashbury - na cidade coincidentemente chamada de $\mathrm{S}$. Francisco - sendo que o consumo de drogas também estaria profundamente ligado a esta perspectiva.

A procura por viver da mendicância fora da vida comercial seria um esforço para manter-se na liminaridade, nos interstícios da vida social daquele tempo vivido por $\mathrm{S}$. Francisco e por seus frades. Neste espaço, a "communitas" poderia surgir. Ao entregarem-se nas mãos da providência procuram seguir o exemplo do cristo nu e crucificado, ele próprio tendo vivido de esmolas, juntamente com sua mãe e discípulos. A fuga da propriedade era também a fuga da estrutura, pois os dois, propriedade e estrutura estão intimamente interlaçados nas formas sociais duradouras com sua estruturação e rotinização.

Nas duas biqueiras por nós frequentadas, assim como, na Cracolândia, as "pessoas sociais" (TURNER, 1974, p. 161) eram representadas por aqueles com maior proximidade com o tráfico de drogas, na posição de vapor ou traficante. Porém, no caso de nossos interlocutores, sua posição como traficante estaria mais próxima aos interstícios da estrutura do tráfico. Era uma posição extremamente frágil, mais próxima de um usuário/vapor e não de um membro fixo em uma estrutura. Seus valores se confundem com os valores dos demais usuários, do mesmo modo como a regra da reciprocidade na treta se aplica também a eles. Compartilham das mesmas condições de vida, embora o vapor esteja mais sujeito às regras do crime organizado quanto à permanência na biqueira e também um pouco mais atrelado a deveres estritos de prestação de contas quanto à quantidade de pedras vendidas.

Citaremos aqui apenas as "pessoas sociais" visíveis em uma biqueira, como a de contenção e vapor. Para o contexto da Cracolândia poderíamos acrescentar as posições de sintonia, disciplina, primo e irmão do Primeiro 
Comando da Capital (PCC). Porém, é necessário salientar a plasticidade destes termos podendo dizer respeito a realidades diversas a depender do contexto vivido, como no caso 'do' sintonia e contenção. Na roda de crack, além de sintonia ser a agradável sensação de fraternidade entre todos os participantes, sensação está muito afeita à ideia de "communitas", na Cracolândia pode dizer respeito à "pessoa social" responsável pela segurança. Na biqueira a céu aberto da Rua São Paulo, o contenção é o responsável por receber quem chega; na biqueira em local fechado também havia alguém nesta posição. Já na roda de crack, contenção pode ser aquele responsável por buscar água, cigarros e Bic caso estes acabem, e até mesmo de colocar as pedras de crack nos cachimbos para garantir quantidades equânimes aos participantes da roda. Aí existe uma verdadeira cooperação "como uma troca em que as partes se beneficiam." (SENNETT, 2012b, p. 15)

Como visto acima, a "communitas" é fugaz, liminar, ela tenderá sempre à estrutura. Assim, com o tempo, a "communitas" espontânea cede às pressões por normatização pela "necessidade de mobilizar e organizar recursos e da exigência de controle social entre os membros do grupo na consecução dessas finalidades, a "communitas" existencial passa a organizar-se em um sistema social duradouro." (TURNER, 1974, p. 161) Na "communitas" normativa está presente o imperativo de mobilizar recursos para o provimento das necessidades da vida, bem como de mobilizar pessoas através de algum tipo de organização social com relações estruturais, comando e obediência. Já na biqueira da Rua São Paulo, na de Amélia e na Cracolândia, o recurso advindo do corre ${ }^{9}$ individual pertence a quem o produziu e esta relação com a propriedade - como vimos

9 Corre é o termo êmico ligado às atividades de obtenção fundos para o uso de crack, porém, "fazer um corre" pode dizer respeito a qualquer movimentação individual no sentido de se atingir algum fim. 
no caso dos frades franciscanos - é fundamental para não deixar florescer "as sementes da segmentação e da hierarquia estruturais." (TURNER, 1974, p. 166) Estamos, portanto, muito próximos a uma situação de igualdade, em um happening socialmente transitório proporcionado pelo uso de crack e pela fruição da sintonia como sentimento de fraternidade por todos os participantes da roda.

$\mathrm{Na}$ Cracolândia, antes do DBA, a estrutura era representada pelas "pessoas sociais" dos disciplinas, primos $e$ irmãos do PCC. As relações diretas e imediatas entre indivíduos poderiam ser vividas no interior do fluxo, nas rodas de crack. O fluxo é tão atraente por ser "communitas", ou seja, indivíduos em relação direta uns com os outros, conversando em pequenos grupos e movimentando-se entre eles. O passar das horas se dá entre velhos e novos conhecidos, todos animados pelo exercício da treta - troca recíproca de bens variados afeitos ou não à parafernália de uso do crack - e pela sintonia proporcionada pelo uso.

Como pudemos presenciar, ao serem convidados a entrar em um estabelecimento comercial (como um bar ou lanchonete), usuário de crack costumam recusar o convite. Esta recusa, longe de ser envergonhada, mais comumente ocorre de modo orgulhoso, quase indignado. Entrar em qualquer bar, sem ser um daqueles pouquíssimos locais disponíveis no interior da Cracolândia, mais especificamente na Rua Dino Bueno, é visto como comportamento de Zé $P^{P o v i n h o}{ }^{10}$ e não de quem "é do crack". Tal qual frades a acompanhar S. Francisco, nossos interlocutores craqueiros romperam os laços com o sistema comercial, em um estado liminar e estabilizado de pobreza "levada até os limites da necessidade." (TURNER, 1974, p. 176) Assim, se os

10 Zé Povinho é o termo utilizado para referir-se aos não usuários de crack e avessos a este uso. São os dispostos a falar mal, olhar de modo julgador, trocar de calçada ao ver pessoas sentadas no chão fazendo uso da droga e mesmo chamar a polícia. 
franciscanos da época de S. Francisco vivo pediam esmolas, nossos craqueiros podem passar seus dias mangueando ${ }^{11}$. Livres da propriedade libertam-se da estrutura, esta fica relegada aos vapores e contenções contadores de dinheiro e prestadores de contas ao tráfico. A acumulação de bens é desencorajada pela própria cultura de uso. Os usuários de crack que em algum momento de sua caminhada ${ }^{12}$ chegam a ter acesso a somas maiores de dinheiro costumam apenas consumir a pedra até o esgotamento dos recursos financeiros.

\section{Conclusão}

O uso do crack é coletivo nos locais observados durante nossa pesquisa. Este uso possibilita a vivência de uma sociabilidade semelhante a "communitas" espontânea procurada tanto pelos hippies quanto por S. Francisco de Assis. Nela, a pobreza é algo fundamental, ela permite a manutenção de um estado desestruturado das relações sociais e possibilita relações fraternais entre despossuídos, marcadas pela reciprocidade das trocas na treta e menos afeita a relações baseadas em "pessoas sociais" com funções estruturadas. Essas mais ligadas aos membros muitas vezes circunstanciais do tráfico de drogas, como o usuário/vapor. Longe de ser "uma substância que dá à pobreza acesso ao sonhado consumo contemporâneo" (MEDEIROS, 2010, p. 182), o crack abre as portas para a negação deste consumo e a vida em "communitas".

11 Nome dado ao ato de pedir esmolas na rua.

12 Caminhada é o termo êmico geralmente referente a história de vida de um usuário de crack, cada qual tendo "sua caminhada", mas também pode dizer respeito a um deslocamento qualquer, "vou sair na caminhada", ou mesmo a alguma história contada por alguém, fulano "já me passou a caminhada" significa ter alguém já contado sobre determinado assunto. 


\section{Referências}

ALVES, Y. Da internação compulsória ao De Braços Abertos: continuidade e inflexão na atenção aos usuários de crack. In: CONGRESSO ARGENTINO DE ANTROPOLOGIA SOCIAL (11. : Rosario, Argentina, 2014). [Anais.] Rosario: 2014.

FELSCHERINOW, C.; VUKOVIC, S. Eu, Christiane F.: a vida apesar de tudo. Rio de Janeiro: Bertrand Brasil, 2014.

FERNANDES, L.; PINTO, M. El espacio urbano como dispositivo de control social: territórios psicotrópicos y políticas de la ciudad. In: Uso de Drogas e Drogodependencias, Monografias Humanitas, n. 5. Barcelona: Fundación Medicina y Humanidades Médicas, 2004. p. 147-62.

FERNANDEZ, O. Coca light? Usos do corpo, rituais de consumo e carreiras de "cheiradores" de cocaína em São Paulo. 2007. Tese (Doutorado em Antropologia). Universidade Federal da Bahia, Salvador.

GRUND, J. P. C. Drug use as a social Ritual: Functionality, symbolism and determinants of self-regulation. Rotterdam Institute Voor Verslavingsondersoek, Erasmus Universiteit, 1993.

JOANIDES, H. Boca do Lixo. São Paulo: Edições Populares, 1978.

MALHEIROS, L. Tornando-se um usuário de crack. In: NERY, E. et al. As drogas na contemporaneidade: perspectivas clínicas e culturais. Salvador: EDUFBA, 2012.

. "Entre sacizeiro, usuário e patrão": Um estudo etnográfico sobre consumidores de crack no Centro Histórico de Salvador. In: MACRAE, E. ; TAVARES, L.A.; NUÑEZ, M.E . Crack: Contextos, Padrões e propósitos de uso. Salvador: EDUFBA, 2013.

MEDEIROS, R. Clínica e croni(cidade): impactos do uso/ 
abuso de crack na configuração urbana e nos tratamentos da toxicomania. In: SAPORI, L.F. ; MEDEIROS, R. Crack: um desafio social. Belo horizonte: PUC Minas, 2010.

RUI, T. C. Corpos Abjetos: etnografia em cenários de uso e comércio de crack. Campinas: UNICAMP, 2012. Tese de doutorado.

SAPORI, L. F.;SENA, L. L.; SILVA, B. F. A relação entre o comércio do crack e a violência urbana na região metropolitana de Belo Horizonte. In: SAPORI, L.F. ; MEDEIROS, R. Crack: um desafio social. Belo Horizonte: PUC Minas, 2010.

SENNETT, R. O artífice. Rio de Janeiro: Editora Record, 2012a.

. Juntos: Os rituais, os prazeres e a política da cooperação. Rio de Janeiro: Record, 2012b.

TURNER, V. O processo ritual: estrutura e antiestrutura. Petrópolis: Vozes, 1974.

ZINBERG, N. E. Drug, Set, and Setting: the basis for controlled intoxicant use. Yale University Press, 1984. 



\section{Parte II}

Cuidado, clínicas e redução de danos 



\section{Algumas diretrizes para a direção de tratamento do recurso subjetivo à substância a partir da Psicanálise ${ }^{1}$}

Cláudia Henschel de Lima

\section{Introdução}

O presente capítulo sintetiza os resultados de pesquisa de orientação psicanalítica conduzida no Laboratório de Investigação das Psicopatologias Contemporâneas, com sede no Departamento de Psicologia da UFF (Instituto de Ciências Humanas e Sociais. Volta Redonda) e referente aos fatores etiológicos do desencadeamento dos sintomas contemporâneos.

A contemporaneidade evidencia um momento de diluição das categorias diagnósticas de neurose e psicose e de ascensão das classes diagnósticas do DSM, seguindo o viés classificatório da antiga psiquiatria e suas bases no modelo biológico. Ao mesmo tempo, testemunha-se a ocorrência de uma variabilidade dos sintomas contemporâneos que designam os seguintes fenômenos clínicos: dependência química, anorexia, bulimia, ataques de pânico, depressão e as patologias do ato.

1 A pesquisa é financiada pela Fundação de Amparo à Pesquisa do Estado do Rio de Janeiro - FAPERJ; PROPPI/UFF e PROEX/UFF. 
Este capítulo é reflexão clínica em torno dos fatores etiológicos do recurso à substância psicoativa, analisando criticamente o impacto da reificação do objeto-droga e da patologização desse recurso, típicas da moral higienista no planejamento de políticas públicas para álcool e outras drogas. Neste sentido, ele se divide em duas partes. A primeira parte consiste em discutir como o higienismo assume lugar hegemônico na formulação de uma política para álcool e outras drogas - em especial, o crack - convertendo a complexidade do recurso subjetivo à substância na massificação de um caso de polícia. A segunda parte toma como base essa denúncia da presença do higienismo e se sustenta em uma interrogação diametralmente oposta e na direção do que vem sendo denominado de caso único: qual a função do recurso à substância psicoativa no funcionamento pulsional de cada sujeito que a consome?

Essa pergunta exigirá a resposta pela psicanálise, na medida em que se especifica por ser uma clínica da singularidade, do caso único, e cuja ação sobre o funcionamento subjetivo consiste em mobilizar as pulsões - ou o que o psicanalista francês Jacques Lacan denomina de gozo - que produzem estragos ao sujeito verificados no declínio de seus laços sociais. Dessa forma, é evidente que o recurso à substância psicoativa, ao obedecer ao imperativo de satisfação pulsional, ao assegurar uma satisfação divorciada do campo da linguagem, impõe o curto-circuito de interrogações referentes a finitude da existência (a sexualidade e a morte) e a ruptura entre o sujeito e o laço social. A localização da droga ${ }^{2}$ no funcionamento subjetivo, com os efeitos de ruptura aqui elencados, esclarece a dificuldade de manejo clínico nesses casos: ausência de demanda (ainda que os efeitos do recurso prolongado à droga sejam mortíferos, isso não é suficiente para a

2 A partir deste momento, o capítulo irá utilizar o termo droga. 
subjetivação do momento em que o sujeito necessita dar um ponto de basta), dificuldade de diagnóstico e complexidade na direção de tratamento, já que a droga é hegemônica e vela a estrutura psíquica.

Nesse sentido, a posição ética da pesquisa conduzida no LAPSICON preserva, para a investigação etiológica do recurso à substância psicoativa, os conceitos fundamentais da psicanálise, formulados por Freud e Lacan: inconsciente, as estruturas psíquicas, o Nome-do-Pai e sua ação reguladora das pulsões no inconsciente. O que define a orientação do capítulo permitindo entender que a droga nunca é a causa da problemática do sujeito. Só a partir do tratamento psicanalítico é possível desvelar os determinantes subjetivos, ligados à desestabilização do funcionamento pulsional, em jogo no recurso à droga. E, sobretudo, o capítulo permite mostrar como a partir de uma clínica orientada pela localização do ponto de desestabilização pulsional, é possível obter uma redução dos efeitos mais devastadores do recurso à droga: overdoses, anorexia por uso abusivo de drogas, comprometimento cardíaco e dentário, parkinsonismo químico.

\section{Da moral higienista à ética da psicanálise}

Em 20 de maio de 2010, a Presidência da República do Brasil publicou o Decreto $\mathrm{n}$ - 7.179, instituindo o Plano Integrado de Enfrentamento ao Crack e outras Drogas, que dispõe sobre a prevenção do uso, o tratamento e a reinserção social de usuários e o enfrentamento do tráfico de crack e outras drogas ilícitas. (BRASIL, 2010) No mês de dezembro de 2011, em continuidade às ações do Governo Federal, foi lançado o Programa Crack, É Possível Vencer, 
(com medidas de integração de ações em três eixos: prevenção, cuidado e autoridade. Ambos enfatizam em suas ações a difusão de informações precisas relativas ao crack e outras drogas ressaltando, ainda, a necessidade de estudos detalhados sobre os sujeitos que fazem consumo de crack no Brasil. Desde o final dos anos de 1980, já se evidenciava um aumento do patamar do consumo de crack no Brasil. (NERY-FILHO et al., 2013)

Em levantamentos nacionais realizados entre os anos de 1994 e 2004 (NOTO et al, 1994; 1998; 2004) identificouse o consumo de solventes como a droga ilícita mais consumida na grande parte das capitais investigadas. Foi o caso, por exemplo, de São Paulo e Recife, que registraram um uso diário de $60 \%$ (consumo de 20 ou mais dias no mês). Além disso, Neiva-Silva (2008) registra o índice de $58 \%$ de uso de solvente no mês, na cidade de Porto Alegre, no grupo de crianças e adolescentes em situação de rua que haviam rompido com o laço familiar. Um dado relevante se refere ao aumento progressivo do consumo de crack na população infanto-juvenil de rua nos últimos anos a ponto de no ano de 1997, passar a ser a forma mais frequente de consumo de cocaína em pedra em São Paulo. No ano de 2003 , o uso no ano chegou a $35.7 \%$ dos entrevistados. No entanto, esses levantamentos apresentam escassez de indicadores precisos sobre a correlação entre uso de crack e situação de rua, abrindo espaço para o discurso higienista de que o crack é uma epidemia típica da miséria e instalada entre crianças e adolescentes em situação de rua. Além da defesa do abrigamento compulsório como procedimento a favor da manutenção da ordem pública e que mistura dois tipos de prescrição, historicamente vinculados ao modelo manicomial, para o tratamento do recurso à droga: prescrição medicamentosa de Haldol e tratamento moral por meio do isolamento social. (HENSCHEL DE LIMA; DUARTE MORAIS; NISHIMURA, 2012) 
Recentemente, destacam-se algumas referências técnicas que se posicionam contrariamente ao estabelecimento de políticas públicas higienistas no Brasil: no campo da pesquisa de levantamentos, o trabalho de Neiva-Silva (2008); o de Morais, Koller e Raffaelli (2012), sobre o modo de vida de crianças e adolescentes que vivem nas ruas; e a pesquisa da Fiocruz (2013) sobre o perfil dos usuários de cracke/ou similares no Brasil; além dos trabalhos de Henschel de Lima et al. (2013) e Henschel de Lima (2014) sobre os determinantes psíquicos do desencadeamento do recurso à droga a partir da referência à psicanálise.

No campo da avaliação crítica da orientação política para o abrigamento compulsório disposto especificamente pela Resolução 20/2011 (RIO DE JANEIRO. SMAS, 2011), vale mencionar, ainda, o estudo recente de Henschel de Lima et al. (2013) que sintetiza os dados da auditoria dos abrigos e CARES-AD do Rio de Janeiro, realizada pela Comissão de Direitos Humanos da Assembleia Legislativa do Rio de Janeiro (ALERJ) nos anos de 2012 e 2013. O estudo evidencia que a política pública da cidade contraria a inovação em saúde mental conquistada pela Lei 10.216/01 (BRASIL, 2001) por se sustentar em uma correlação não demonstrada entre situação de rua e uso de crack, mantendo o paradigma manicomial de isolamento social, medicalização excessiva e homogênea por Haldol e a imposição de uma direção religiosa para o tratamento da questão delicada do recurso à droga na situação de rua. (HENSCHEL-LIMA et al., 2013) O estudo alerta, também, para a ocorrência de uma correlação não demonstrada, não verificada, entre situação de rua e uso de crack no sentido de ressaltar como a implementação da política pública no Rio de Janeiro produz, fixa e naturaliza a equação situação de rua e indivíduo perigoso e converte o abrigamento compulsório em punição.

Essas considerações indicam que o procedimento higienista toma a gravidade e extensão do problema do 
consumo abusivo de substâncias a partir exclusivamente do valor patológico da droga, refletindo a afirmação de Laurent (1998) de que a preocupação com a saúde mental está orientada exclusivamente pela saúde em detrimento do psíquico. Em contraposição ao higienismo típico da formulação e da implementação das políticas públicas, a psicanálise permite entender que a droga não é a causa da problemática do sujeito, sendo indispensável as referências aos determinantes subjetivos, ligados a desestabilização do funcionamento pulsional em jogo no recurso à droga. Considerar o desencadeamento do consumo abusivo de substâncias psicoativas sob a perspectiva psicanalítica permite o esclarecimento dos determinantes psíquicos para a indiferença ou ruptura com o laço social e o declínio do sentimento de vida que acometem o sujeito nessas situações.

Psicanálise e diagnóstico estrutural do recurso à droga

Sou o cachimbo de um autor. Vê-se, ao se contemplar a minha De Abissínio ou Cafre linha, Que meu dono é bom tragador.

Quando ele está cheio de dor, Eu libero uma fumacinha Como a chaminé da cozinha Na volta do trabalhador.

Sua alma acalentando eu cuido Na rede azulada e movente Que sai de minha boca ardente,

E emano um poderoso fluido Que encanta o seu peito a curar 
De seus cansaços seu pensar.

(Charles Baudelaire. O Cachimbo)

A poesia de Baudelaire deixa evidente que uma droga não produz efeito por si só. Em se tratando de absintho ou haxixe, trata-se do valor de uso singular ocupado pela fumaça azulada do cachimbo para o poeta. A indicação sobre o valor de uso singular é ofuscada pela amplitude da fenomenologia dessas situações: forte compulsão para usar a droga; dificuldade em controlar seu consumo; síndrome de abstinência ou uso da droga para evitar o aparecimento da mesma; tolerância.

A complexidade desses casos é que, devido à gravidade de sua fenomenologia e da adesão à uma identificação imaginária (sou toxicômano, sou dependente químico) em torno da qual se ordenam suas histórias clínicas, acabam por induzir o clínico à dúvida quanto às condições subjetivas que estão na base do recurso à droga. No entanto, a literatura psicanalítica mais atual sobre o tema vem sustentando indicações relevantes sobre o consumo de substâncias a partir da pesquisa mais pormenorizada de seu assentimento subjetivo. Por exemplo, Alberti, Inem e Rangel (2003) afirmam que alguns sujeitos, apesar de fazerem uso regular de uma substância psicoativa por vários anos, não se consideram adictos, pelo fato desta não ocupar lugar preponderante em suas vidas, não verificando as características do CID-10 para o diagnóstico de Transtorno por Uso de Substâncias. Por outro lado, citam a ocorrência de casos em que os sujeitos consomem substâncias psicoativas com a mesma frequência e ao longo de período similar de tempo e que se consideram adictos pela ação devastadora da substância em suas vidas. Outras referências problematizam ainda mais a relevância do objeto droga na abordagem do problema. 
O estudo de caso publicado por Abello (2009), sobre toxidade pela água em um paciente que sofrera uma cirurgia renal, e por Naparstek (2009) sobre a identificação de um sujeito à posição de dependente químico a partir de um anúncio onde teria lido se é um dependente químico, então procure nossa clínica, indicam a relevância da toxidade pulsional no recurso ao objeto. Ambos os estudos evidenciam a extensão do problema do consumo abusivo de substâncias para além de um problema epidêmico e da explicação neurofisiológica pelo efeito químico das substâncias psicoativas. Ele está em íntima conexão com os quadros de desestabilização pulsional no funcionamento psíquico. O foco na pesquisa desses quadros de desestabilização permite explicar a instabilidade do recurso, a alternância com as recaídas, bem como a fenomenologia apresentada. Sendo assim, a investigação sobre a relação entre consumo de substâncias e estrutura psíquica se converte no eixo central da psicanálise, definindo os critérios de distinção entre os usuários e as modalidades de uso a partir das condições subjetivas de seu desencadeamento, bem como a elaboração de uma direção de tratamento a partir do diagnóstico diferencial entre neurose e psicose.

Seguindo, então, essa orientação epistemológica, trabalharei com a hipótese de que a etiologia psíquica, as condições subjetivas, do recurso à droga não está diretamente relacionada à fenomenologia desses quadros, mas está intimamente articulado a fatores de estrutura psíquica - ao que foi referido, aqui, como assentimento subjetivo. Deste modo, o recurso à droga pode responder tanto à estagnação do funcionamento da estrutura no primeiro tempo lógico do Édipo pela baixa operatividade do Nome-do-Pai no caso de neuroses, como à foraclusão - à recusa do Nome-do-Pai - no caso das psicoses. 


\section{A teorização do Nome-do-Pai}

A contemporaneidade evidencia um momento de diluição das categorias diagnósticas de histeria e psicose e de ascensão das classes diagnósticas do DSM, seguindo o viés classificatório da antiga psiquiatria e suas bases no modelo biológico. Ao mesmo tempo, testemunhase a ocorrência de uma variabilidade dos sintomas contemporâneos (síndromes do pânico, toxicomanias, depressões, anorexias, bulimias) na clínica psicanalítica, distintas do quadro clássico das estruturas psíquicas. Como, então, as estruturas psíquicas são abordadas no quadro de época que define o diagnóstico e a direção do tratamento das psicopatologias a partir desse quadro epistemológico?

A teorização do Nome-do-Pai é de fundamental importância para a psicanálise na medida em que é - operador da constituição das estruturas psíquicas. Determinar sua operatividade é essencial para a elaboração do diagnóstico diferencial e, consequentemente, para definir a ação do profissional diante dessas situações. Freud (1973a; 1973b) já evidenciara o caráter determinante do pai simbólico na formação do laço social e da estrutura psíquica.

Sua hipótese é que o laço social se estrutura a partir do assassinato do pai da horda primitiva que condensa em si uma satisfação pulsional desmedida, do erguimento da impossibilidade de acesso à esta satisfação pulsional para todo sujeito, pela lembrança da morte do pai e da emergência da experiência subjetiva do mal-estar. A hipótese particularizar-se-á na existência individual por meio da triangulação do complexo de Édipo, formada pelos termos: Nome-do-Pai ${ }^{3}$, Desejo da mãe e criança.

Esta triangulação se refere à entrada do sujeito na

3 A partir desse momento, será utilizada para Nome-do-Pai, a abreviação NP. 
civilização, por meio da regulação das pulsões pelo NP. Mas depende ainda da introdução do falo - quarto termo que ordena as pulsões (o gozo) da mãe e da criança, além de localizar o pai como pai simbólico. Ao se colocar como quem possui o elemento fálico, o pai pode atuar como regulador da economia pulsional formada na relação entre mãe e criança. A função estruturante do NP se dá quando o pai assume a posição de quem tem o objeto do desejo da mãe: ele detém o poder e encarna a função de lei interditora sobre a economia pulsional entre mãe e criança.

A problemática do pai é normalmente teorizada a partir da referência freudiana ao complexo de Édipo. Assim, o pai é pensado como significante da lei, segundo uma operação que substitui o desejo (materno) pela lei (paterna), e introduz uma significação nova no mundo simbólico do sujeito. No entanto, uma leitura cuidadosa do ensino de Lacan (1992), revela uma produção conceitual em torno do Nome-do-Pai que vai além do complexo de Édipo interpretado pelo próprio autor em 1969 como mito, quando questiona o valor do complexo de Édipo como estruturante da subjetividade. Essa produção conceitual tem início, em 1953 com "Função e campo da fala e da linguagem na psicanálise" e "O mito individual do neurótico", destacando o pai em sua função simbólica. Em "O seminário: livro 3. As Psicoses", Lacan (1988) postulará que o pai é um significante: o NP. E seu registro é o do recalcamento/foraclusão: ele pode estar ausente, foracluído, na psicose e presente como estruturante do funcionamento psíquico na neurose.

A partir de "O seminário: livro 4. A relação de objeto" (LACAN, 1995) e "O seminário: livro 5. As Formações do Inconsciente", Lacan (1999) desloca a leitura do NP, da interdição do desejo, para o que é possível à estrutura subjetiva a partir de sua ação. Esta nova leitura do NP, a partir de sua operatividade, advém do modo como um pai se posiciona como homem na relação com a mulher. 


\section{Recurso à droga e estragos estruturais}

Tenho onze filhos. O primeiro tem uma aparência pouco agradável, mas é sério $e$ inteligente; apesar disso, por mais que eu o ame, como amo a todos os outros, não o tenho em alta conta. Seu modo de pensar me parece simples demais. Não enxerga nem à direita nem à esquerda e tampouco a distância; em seu restrito círculo mental, ele só fica sempre dando voltas (...). O segundo é bonito, esbelto, bem proporcionado; é um encanto vê-lo na postura de esgrimista. (...) E apesar de tudo isso (eu deveria, afinal, estar realmente feliz por ter um filho assim), meu relacionamento com ele não é despido de perturbações. Seu olho esquerdo é um pouco menor que o direito e pisca muito; (...) Naturalmente não é esse defeito corpóreo que me dói e machuca, mas uma, de algum modo equivalente, pequena irregularidade em seu espírito, algum veneno errante em seu sangue (...). (...) O terceiro filho também é bonito, mas não é do tipo de beleza que me agrade. (...) Apesar de em geral tudo induzir à exibição desse filho, prefiro mantê-lo oculto; (...) Ele inclusive se sente um estranho em nossa época: como se pertencesse à minha família (...) com frequência ele está deprimido e nada consegue animálo. O meu quarto filho talvez seja o mais sociável de todos. Verdadeiro filho de sua época, (...) gostamos de repetir algumas de suas assertivas, mas só algumas, pois no conjunto ele, porém, padece por sua vez de demasiada superficialidade. É como alguém que salte maravilhosamente bem, fenda o ar qual uma andorinha, mas acabe aterrissando desoladoramente em mísera 
poeira: um nada. Tais pensamentos me amarguram à visão desse filho. O quinto filho é amável e bom; prometia bem menos do que acabou concretizando; ele era tão insignificante que em sua presença a gente se sentia formalmente só; mas acabou conseguindo conquistar um certo renome. Caso se pergunte como isso aconteceu, dificilmente eu saberia responder. (Franz Kafka. Onze Filhos)

O conto de Kafka testemunha a operatividade da ação do pai, isso que Lacan definiu como sendo a armadura do amor do pai, no destino da vida de um filho: desde a sua operatividade mínima até o espectro da sua recusa mais fundamental - isso que identificamos como sendo algo de podre na transmissão de um pai nas psicoses. A evidência clínica primeira, nos casos em que o recurso à droga é hegemônico, é justamente esse espectro da podridão da transmissão paterna - tão bem testemunhada por Kafka em sua época - e que passou a dominar a cena do funcionamento subjetivo contemporâneo. A pesquisa mais aprofundada sobre a ação do NP no funcionamento subjetivo vem sendo fundamental para a verificação da hipótese de que a etiologia do recurso à droga indica a necessidade de localizar o índice de operatividade do NP - desde sua recusa, sua foraclusão, até sua mais baixa operatividade típica do primeiro tempo lógico de efetuação da estrutura na neurose. Sendo, então, fundamental para a localização:

1. Do ponto onde a ação do NP se fragiliza (neurose) ou sofre recusa (psicose);

2. Do desencadeamento da invasão pulsional sofrida pela estrutura equea fixa em nomeações monossintomáticas - também conhecidas como nomeações de massa (S1) em referência a identificação de massa definida por Freud. Na 
nomeação de massa, o NP funciona apenas como nomeação simbólica, como série de nomes pré-existentes.

Retomando a posição subjetiva do pai em "Onze Filhos," entende-se que sua operatividade supõe, para além do nome, a arte de transmiti-lo. Nesses casos, o NP não chega a ser o que amarra e sustenta a estrutura psíquica. Assim, em termos clínicos o não funcionamento do amor do pai como armadura pode fixar a estrutura no ponto de foraclusão (para as psicoses) ou no ponto de alienação nas neuroses, acarretando uma gama de estragos no corpo homogêneos para ambas as estruturas psíquicas e que ameaçam a vida do sujeito: anorexia química, parkinsonismo químico, overdoses e recaídas - além da fixação nas nomeações de massa (sou dependente químico, sou cracudo). Essa homogeneidade dos estragos é o que orienta a psiquiatria biológica contemporânea na direção de classificar o recurso à droga como transtorno por uso de substâncias suprimindo a dimensão do caso único como bússola para o estabelecimento da direção de tratamento desses casos. Determinar se o não funcionamento do amor do pai como armadura fixa a estrutura no ponto de foraclusão ou no ponto de alienação permite a delimitação da hipótese a respeito da estrutura psíquica em jogo no recurso à droga e, consequentemente, uma ação mais precisa do profissional sobre o ponto de desestabilização pulsional sofrida nesses casos. Uma clínica orientada pela localização desse ponto de desestabilização permite obter uma redução dos efeitos mais devastadores do recurso à droga: overdoses, anorexia por uso abusivo de drogas, comprometimento cardíaco e dentário, parkinsonismo químico. Algumas indicações clínicas extraídas da literatura científica mais recente evidenciam o modo de trabalho do profissional orientado pela perspectiva psicanalítica. Em um estudo de caso em psicanálise extraído da literatura científica nacional, Calmon (2010/2011) examina um caso 
de recurso à droga que revela a posição de objeto para o Outro, sofrida pelo sujeito na mesma direção dos filhos do conto "Onze Filhos", que se reduzem a meros objetos da crítica paterna mais excludente. Há também o estudo de caso conduzido por Henschel de Lima (2013) em que o recurso ao crack e o destino para a situação de rua no quadrilátero de casa de sua mãe, em uma jovem de 21 anos, respondem diretamente à ascensão estragante das palavras maternas mais ofensivas em seu funcionamento subjetivo: preguiçosa, agressiva, perigosa, prostituta.

$\mathrm{Na}$ literatura científica internacional, destacam-se os estudos de caso de Naparstek (2009), Briolle (2009) e Aucremanne (2011). Aucremanne (2011) se refere à função de ruptura operada pela substância em casos em que o Outro advém sobre o sujeito seja sob a forma do excesso - nas versões do invasivo, ameaçador - seja sob a forma de um demasiado pouco, nas versões do deixar cair, da negligência. $\mathrm{O}$ autor, com isso, indica que a localização do Outro no caso clínico e o modo como a droga se localiza no quadro de suas versões podem oferecer alguma bússola para o diagnóstico de psicose. Em outro estudo de caso, Naparstek (2009) sustenta que a função da droga em casos de psicose não produz necessariamente, um excesso de gozo funcionando, ao contrário, para limitar o gozo no corpo indicando a importância do clínico localizar as circunstâncias de vida do paciente que desencadeiam a invasão pulsional e o recurso à droga. No entanto, o autor alerta para o fato de que esta solução deixa o sujeito no limite da passagem ao ato por representar um tratamento, um pharmakon da invasão pulsional no corpo, que produz colateralmente a mesma invasão pulsional. 


\section{Considerações Finais}

Ao longo deste capítulo foi possível elucidar que - problema clínico que se coloca para os casos em que prepondera o recurso à droga é: por que um sujeito recorre à droga? $\mathrm{O}$ que indica que a efetividade da direção de tratamento desses casos depende da consideração do estatuto da droga em íntima articulação com os fatores estruturais assim descritos:

1. Na psicose: o recurso à droga é uma variável dependente da foraclusão do Nome-do-Pai.

2. Na neurose: o recurso à droga é uma variável dependente da baixa operatividade do Nome-do-Pai.

Essa orientação se opõe francamente à orientação higienista das políticas públicas que sustentam a abstinência da droga por assumir um valor patológico intrínseco, o isolamento social e a medicalização homogênea como direção única de tratamento para todos os casos. Sabemos os efeitos excludentes dessa orientação: a fixação em nomes de massa ou no que Henschel de Lima et al. (2013) referiram como nome-do-pior.

\section{Referências}

ABELLO, M. El Água Tóxica de Mario. In NAPARSTEK, F. (org.). Introducción a La Clínica con Toxicomanías Y Alcoholismo II. Buenos Aires: Grama Ediciones, 2009. p. 6-13.

ALBERTI, S. et al. Fenômeno, Estrutura, Sintoma e Clínica : A Droga. Revista Latinoamericana de Psicopatologia Fundamental, São Paulo, v. 6, n. 3, p. 11-29, 2003. 
AUCREMANNE, J.L. Las Conversaciones del TyA. Pharmakon: Chifladuras Adictivas, Buenos Aires, v. 12, p. 61-66, 2011.

BRASIL. Presidência da República. Casa Civil. Lei 10.216, de 06 de abril de 2001. Disponível em: <http://www.planalto. gov.br/ccivil_03/leis/leis_2001/l10216.htm>. Acesso em: 10 jul 2014.

BRIOLLE,G. Toxicomanía. Un lazo social entre otros? Pharmakon: El Lazo Social Intoxicado Buenos Aires, v. 11, p. 43-50, 2009.

CALMON, A. A droga ou a vida. aSEPHallus, Rio de Janeiro, v. 6, n. 11, p. 86-97, nov. 2010 / abr. 2011. Disponível em: $<$ www.nucleosephora.com/asephallus $>$. Acesso em: 10 Jun 2012.

FIOCRUZ. Perfil dos usuários de crack e/ou similares no Brasil. Rio de Janeiro: Fundação Oswaldo Cruz, 2013.

FREUD, S. O Mal-Estar na Civilização. In: SALOMÃO, J. (Org.) Edição Standard Brasileira das Obras Psicológicas Completas de Sigmund Freud. Rio de Janeiro: Imago, 1973b. v. XXI.

- Totem e Tabu. In: SALOMÃO, J. (Org.) Edição Standard Brasileira das Obras Psicológicas Completas de Sigmund Freud. Rio de Janeiro: Imago, 1973a. v. XIII, p. 17198.

HENSCHEL DE LIMA, C. Que destino para a atenção psicossocial orientada pela psicanálise no contexto da teologia da normalidade? In: ENCONTRO AMERICANO DE PSICANÁLISE DE ORIENTAÇÃO LACANIANA (6. : 2013 : Buenos Aires, AR); ENCONTRO INTERNACIONAL DO CAMPO FREUDIANO (18. : 2013 : Buenos Aires, AR). Hablar com el cuerpo. La crisis de las normas y La agitación de lo real. Buenos Aires: Associação Mundial de Psicanálise, 2013.

- Investigação psicanalítica dos determinantes 
psíquicos do consumo abusivo de substâncias psicoativas. Revista Latinoamericana de Psicopatologia Fundamental, São Paulo, v. 17, n. 1, p. 38-49, mar. 2014.

HENSCHEL DE LIMA, C.; DUARTE MORAIS, D. ; NISHIMURA, A. Quando a Política Pública para Álcool e Outras Drogas, no Brasil, contraria o Processo de Inovação. CONGRESSO DE ADMINISTRAÇÃO SOCIEDADE E INOVAÇÃO. Anais. Volta Redonda, Universidade Federal Fluminense, 2012.

HENSCHEL DE LIMA, C. et al. Crack: Uma Abordagem Psicanalítica de seu Consumo entre Crianças e Adolescentes em Situação de Rua. Revista Mal-estar e Subjetividade, Fortaleza, v. XIII, n.1-2, p. 155-194, mar./jun. 2013.

KAFKA, F. Onze Filhos. In: KOTHE,F. (Org.). Galerias. São Paulo: Ed. Clube do Livro, 1989. p. 96-100.

LACAN, J. O seminário. Livro 3: As Psicoses. Rio de Janeiro: Jorge Zahar, 1988.

. O Seminário. Livro 4. A Relação de Objeto. Rio de Janeiro: Jorge Zahar. 1995.

. O seminário. Livro 5: As formações do inconsciente. Rio de Janeiro: Jorge Zahar, 1999.

. O seminário, Livro 17: O Avesso da Psicanálise. Rio de Janeiro: Jorge Zahar, 1992.

LAURENT, E. Mental?. Pharmakon, Buenos Aires, v. 6-7, p. 87-90, 1998.

MALENGReAU, P. Clínica del Toxicómano. Pharmakon: EI Lazo Social Intoxicado, Buenos Aires, v. 11, p. 35-42, 2009.

MINISTÉRIO DA SAÚDE. Secretaria de atenção à saúde. Departamento de ações programáticas estratégicas. Coordenação geral de saúde mental, álcool e outras drogas. Saúde Mental em Dados 10. Brasilia, Ano VII, no 10, março de 2012. Disponível em: <http://saudeecosol.files. 
wordpress.com/2012/03/saude-mental-em-dados-10-ms. pdf $>$. Acesso em: 10 Julho 2014.

MORAIS, N. A.; KOLLER, S. H.; RAFFAELLI, M. Rede de apoio, eventos estressores e mau ajustamento na vida de crianças e adolescentes em situação de vulnerabilidade social. Universitas Psychologica, v. 3, n. 11, p. 779-791, 2012.

NAPARSTEK, F. La alucinación en la intoxicación y en la psicosis. Pharmakon: El Lazo Social Intoxicado, Buenos Aires, v. 11, p. 35-42, 2009.

NEIVA-SILVA, L. Uso de drogas entre crianças e adolescentes em situação de rua: Um estudo longitudinal. Porto Alegre: UFRGS, 2008. Tese (Doutorado) - UFRGS, Rio Grande do Sul, 2008.

NERY-FILHO, A. et al. Diálogo com Dr. Antonio Nery Filho, George Gusmão Soares, Maria Eugenia Nuñez e Edward Macrae sobre o Crack. In: MACRAE, E. ; TAVARES, L.A.; NUÑEZ, M.E . Crack: Contextos, Padrões e propósitos de uso. Salvador: EDUFBA, 2013.

NOTO, A. R. et al. III levantamento sobre uso de drogas entre crianças e adolescentes em situação de rua de cinco capitais brasileiras. São Paulo: CEBRID, 1994.

- IV levantamento sobre uso de drogas entre crianças e adolescentes em situação de rua de seis capitais brasileiras. São Paulo: CEBRID, 1998.

. Levantamento nacional sobre uso de drogas entre crianças e adolescentes em situação de rua de $\mathbf{2 7}$ capitais brasileiras. São Paulo: CEBRID, 2004.

RIO DE JANEIRO. SMAS. Resolução n. 20 de27de maio de 2011. Disponível em: <http://www0.rio.rj.gov.br/pcrj/ estrutura_nova/smas.shtm>. Acesso em: 05 jun. 2014. 


\section{Afirmar a clínica com pessoas que usam drogas desde um lugar de resistência}

Flávia Fernando Lima Silva

Escutar é obviamente algo que vai mais além da possibilidade auditiva de cada um. Escutar, no sentido aqui discutido, significa a disponibilidade permanente por parte do sujeito que escuta para a abertura à fala do outro, ao gesto do outro, às diferenças do outro. (FREIRE, 1996, p. 119)

Tecer uma clínica com pessoas que usam drogas em nossos tempos é, decerto, sustentar uma resistência. Certa concepção de cidade, higienizada, pacificada, ordenada, consonante à "Guerra às Drogas", em seus efeitos de criminalização e exclusão, atravessa as linhas duras das políticas para usuários de álcool e outras drogas. Uma clínica, não é demais afirmar, se dá em um contexto.

Claude Olievenstein (1990) ao falar da clínica das toxicomanias apontava a necessidade de se pensar um triângulo entre a droga, o sujeito e a sociedade em seu momento sociohistórico. De um modo geral temos olhado para a substancia, muito mais que para os sujeitos ou para as questões sociohistóricas. E isto não se dá sem consequências. 
Discutiremos aqui alguns discursos maiores sobre as drogas e seus usuários - discursos hegemônicos, que são repetidos e que podem ser ditos. Na ordem do discurso, chamamos, com Foucault, essas narrativas de dominantes. (FOUCAULT, 2005a) As narrativas menores ${ }^{1}$ são periferizadas, não cabem na ordem do discurso.). Propomos que para construir outra clínica com essas pessoas faz-se necessário olharmos a partir de outras perspectivas e, por conseguinte, tecer e sustentar outras narrativas em geral invisibilizadas sobre este tema.

Comecemos pelas narrativas dominantes, verdadeiros refrões, naturalizados, repetidos ad nauseum, sem maiores questionamentos. Na literatura sobre o tema e no discurso de diversos grupos de ajuda mútua há um enunciado em especial, atribuído à OMS (Organização Mundial de Saúde), que tem sido incansavelmente repetido: "A dependência química é uma doença primária, crônica, progressiva e de determinação fatal". Vale nos debruçarmos sobre as diversas partes deste enunciado. $O$ que significa afirmar que uma doença é primária? Podemos acenar com isto para algo que não tem uma causalidade além, o que daria à doença a condição de secundária. Uma doença primária "nasce" em si mesma. Mas não apenas a dependência química seria primária, seria também crônica, se estenderia ao longo do tempo, com uma evolução progressiva, isto é, vai se desenvolvendo e se intensificando a cada ano que passa.

Não bastasse ser chamada de primária, crônica e progressiva, é enunciado que apresenta uma determinação fatal. O sujeito dependente químico teria a doença que se manifestaria no encontro com a substância psicoativa e isto seria uma condição permanente que o levaria necessariamente à morte. A definição em tela não

1 Menor no sentido de seu possível caráter insurgente, minoritário. (DELEUZE; GUATTARI, 2002) 
considera contexto, comorbidades, singularidades, nem a possibilidade, eventualmente, de remissão. Está implícito um caráter imutável que aponta para uma condição que teria como único tratamento realmente efetivo a abstinência completa. Sendo que ante uma recaída, por esta leitura da dependência, se retornaria rapidamente à síndrome de dependência. Tornou-se comum uma metáfora de uma vela que é apagada quando da abstinência da substancia, sendo que diante do retorno ao uso, a vela voltaria a queimar do ponto em que parou.

Quais as possíveis implicações desse "modelo conceitual"? Compreender uma doença como primária pode contribuir para, como afirmamos antes, incorrermos em uma desconsideração do contexto em que se dá o uso e a construção da dependência. Todos os aspectos envolvidos, do ponto de vista do ambiente familiar e social, passam a ser vistos como consequências do uso e da dependência e não como fatores de possível influência mútua ou compondo uma etiologia multifatorial. A compreensão da dependência química como uma condição primária pode contribuir ainda para uma suposição de que tratar significa necessariamente conduzir à abstinência completa e, ainda mais, que estar abstinente signifique estar "tratado", perdendo de vista toda a complexidade do plano relacional da pessoa e seu funcionamento psíquico ou modo de existência. Promover a abstinência sem considerar e tratar os diversos aspectos envolvidos, sobretudo relacionais, além de apontar para um reducionismo pode resultar em um incremento do sofrimento da pessoa com dependência, se consideramos que o uso de substancia e uma possível dependência pode sugerir uma forma de lidar com dificuldades ou dores anteriores à instalação do quadro de dependência.

Pechansky e Luborsky (2005), em um artigo sobre abordagem psicodinâmica do paciente dependente químico, relatam uma vinheta clínica a respeito de um homem que 
frequentava um grupo de ajuda mútua, alcoolista, há muitos anos em abstinência de álcool. Um olhar cuidadoso para o seu funcionamento psíquico mostrou que pouco havia se modificado em sua vida, no que concerne a outros modos de se relacionar afetivamente, com o trabalho, ou algo que chamaríamos aqui de uma ampliação do seu repertório, em contraponto a um estreitamento do repertório, clássico em situações de dependência de uma substancia. Os autores evocam um modelo teórico compreensivo definido como "hipótese da automedicação." (KHANTZIAN, 1985) Esta teoria postula que o uso de drogas pode ter haver com tentativas do indivíduo de lidar com o ambiente externo e interno, no sentido de aliviar possíveis desconfortos anteriores, em uma investida de autorregulação, de buscar uma homeostase ou equilíbrio psíquico. Retirar a substancia sem ofertar, ou melhor, construir outros modos de lidar com tais dificuldades, poderia produzir uma piora na condição de vida da pessoa em tratamento.

No contexto atual, assistimos a toda uma discussão sobre a dita epidemia do crack, em que neste movimento de acento sobre a substância - em detrimento de pensar o sujeito e o momento sociohistorico - acabamos por atribuir uma ampla produção de vulnerabilidade e sofrimento a ela, atribuindo um poder de produção grandioso à mesma, sem enxergarmos o seu entorno. Leituras simplistas inevitavelmente resultam em intervenções também simplistas, numa lógica bélica de combate ao crack e não de cuidado às pessoas que usam. Não atentar para a história dos sujeitos nem para o contexto sociohistórico contribui para a construção de políticas de governo e também de uma clínica em que a marca é a simplificação e a precariedade do pensamento. Uma lógica que posiciona a substancia como geradora de todo o mal ora simplifica a leitura de doença primária, ora criminaliza a substancia e o usuário, culpabilizando os sujeitos e demonizando as substancias. A 
parte do enunciado que coloca a dependência química como doença de determinação fatal, no caso do crack, assume proporções exuberantes e dramáticas. A vulgata que afirma que ao primeiro uso desta substância o usuário se torna dependente, coaduna com a produção de um imaginário de monstruosidade associado ao usuário, mortos vivos, que oscilam das categorias "em perigo" e "perigosos", sem se excluírem entre si.

Enquanto o estranho está a nossa frente, podem surgir evidências de que ele tem um atributo que o torna diferente dos outros que se encontram numa categoria em que pudesse ser incluído. Assim deixamos de considerá-lo criatura comum e total, reduzindo-o a uma pessoa estragada e diminuída. Tal característica é um estigma, especialmente quando o seu efeito de descrédito é muito grande. (GOFFMAN, 1988, p. 12)

A produção do estigma empobrece a política e a clínica (entendendo que toda clínica é também política), além de gerar mais sofrimento e exclusão, ou ainda inclusão em lógicas perversas de controle e tutela, a exemplo das internações compulsórias em massa. O estigma fecha nossa visão para a largueza do outro.

Outra narrativa dominante comumente repetida é afirmar uma personalidade do dependente, com características fixas, em geral pejorativas, como baixo limiar à frustração, mentiroso e manipulador. Diz-se que "dependente químico é assim mesmo, manipulador", "Cuidado pra não ser manipulado..." e "Eles não costumam falar, não subjetivam...". Essas observações a respeito de uma suposta personalidade do dependente apontam para uma leitura moral que enviesa o olhar e toda tentativa de construção de vínculo. É como se o profissional de saúde 
ou assistência social, principalmente na clínica, tivesse que ser "esperto", tivesse que estar atento às armadilhas que o usuário/dependente estaria armando na relação.

"Saber" muito sobre o outro pode nos impedir de ver o que está para além de nossas concepções prévias. Estas podem contribuir para fixar sentidos na relação, fechando as possibilidades para a multiplicidade, as possíveis nuances naquele modo de existência. "Saber demais" pode dificultar a nós, clínicos, ocuparmos um lugar de não saber e com isso, abrirmos caminho para os saberes do outro. Uma das queixas mais comuns entre os que trabalham com dependentes químicos é que "eles não falam". Ou que falam de tudo, menos de si. Talvez aqui valesse uma reflexão sobre como posicionamos a nossa escuta. Será que estamos abrindo nossa perspectiva a uma escuta radical? Uma escuta que dê passagem a narrativas para além do óbvio? Lembro-me do poeta Carlos Drummond de Andrade (2013): "se meu verso não deu certo, foi seu ouvido que entortou...". Se ouvimos "mais do mesmo", será que os sujeitos que ouvimos são mesmo iguais ou nossos ouvidos tortos só conseguem dar passagem a determinadas narrativas? Será que uma escuta "viciada" não produziria enquadres limitadores? Quanto da nossa posição subjetiva não faz falar alguns discursos monocórdicos ou silenciar discursos dissonantes? Petuco (2011) diz que existem apenas dois discursos autorizados às pessoas que usam drogas: o discurso do derrotado ou desesperado, dos que vem buscar ajuda de um modo subserviente, e o discurso vitorioso ou heroico, daqueles que superaram o uso de drogas e se colocam como heróis. Caso nossa escuta assumisse uma radicalidade, de se permitir ir à raiz da experiência do outro, quais outros discursos adviriam? Que outras narrativas insurgiriam?

Miller e Rollnick (2001) problematizam a ideia de uma personalidade dependente. Questionam como 
os profissionais tornaram-se tão convencidos de que alcoolistas e outros usuários de drogas são pessoas caracteriologicamente mentirosas, racionalizadoras, evasivas e resistentes e que precisam ser tratadas como tais. Colocam em xeque os modos que os terapeutas lidam a partir dessas leituras, através de manejos combativos e confrontadores, que terminam por gerar respostas previsíveis de negação e resistência, ao modo de uma profecia autorrealizável.

Ainda outra possibilidade é a de que o estilo interpessoal e o contexto do aconselhamento para dependentes terminem por criar uma uniformidade no comportamento dos pacientes através dos processos psicológicos previsíveis. (MILLER; ROLNICK, 2001, p. 28)

É lugar comum a afirmação de que só é possível existir tratamento se houver demanda do "paciente". Afirmação que é enunciada por alguns especialistas como desejo ou ainda força de vontade. Esta exigência frequentemente resulta em frustração para o profissional, levando-o muitas vezes a assumir posições mais duras ante o que chama desimplicação ou descomprometimento do usuário/ dependente. No entanto, se pensamos o tratamento como um espaço de construção, espaço de tecer um ver, um tempo de compreender e só após isso, um momento de concluir (CONTE, 2003); damo-nos conta que a demanda não está dada, nem mesmo o desejo. É no tratamento, num espaço relacional, inclusive transferencial e de construção de vínculo, que é possível tecer algo que aponte para uma demanda e quiçá um desejo. De algum modo, talvez seja preciso que algo em nós, que nos propomos a tratar, seja emprestado a este outro, para darmos partida à construção conjunta ao que chamamos tratamento. Uma espécie de oferta ou aposta. Se estivermos diante de uma experiência 
de uso compulsivo ou de uma dependência, é importante que lembremos que o sujeito à nossa frente tem questões com o que denominamos de liberdade, escolha e vontade. Algo nesse circuito parece titubear. De modo que a complexa assunção de uma liberdade de escolha e da vulgar força de vontade, são parte da construção que deve se dar no tratamento. Caso esperemos que isto esteja dado, pronto, resvalamos em uma ingênua exigência que nada contribui aos tempos do tratamento. Há um time, sobre o qual é valioso estarmos atentos. Um ritmo tecido no calor do encontro e do entorno. Este tempo é singular. E vivo. Mais próximo do jazz que da sinfonia.

Prochaska e Diclemente (1982) descreveram a mudança em estágios pelos quais as pessoas passam no curso da modificação de um problema. Criaram um modelo do qual derivou a chamada "roda da mudança". A ideia de roda nosajuda a pensar que a mudança tem um movimento e que circula. Compreende-se também que o manejo que o terapeuta faz, considerando o momento em que o sujeito se encontra, face à mudança, pode contribuir para facilitar ou dificultar esses tempos. A recaída faria parte do processo de mudança, inclusive, dispensando leituras morais e culpabilizadoras que mais paralisam que abrem caminho para a ampliação daquela existência.

Detenhamo-nos na ideia subjacente à categoria dependência química. Notemos que na nomeação desse constructo é o aspecto químico que é ressaltado, como se fosse a química que ocupasse a centralidade da experiência. Por esta perspectiva, a substância ocupa uma posição de protagonismo, de forma que apenas produzindo uma abstinência é que se considera o tratamento bem sucedido.

Já a perspectiva psicanalítica situa a toxicomania como um sintoma, apontando para algo além dela mesma. Torossian (2004), inspirada por Le Poulichet, assinala uma 
relação tóxica entre o sujeito e a droga nas toxicomanias, quando a droga passa a ser consumida na tentativa de solução para conflitos psíquicos preexistentes. Conte (2003) acena para uma possível base melancólica para a toxicomania. Estas autoras partem de construções mais complexas, que consideram as relações, os modos de lidar com as questões da existência.

A ideia de toxicomania evoca a dimensão da paixão, a qual seria de bom tom lembrar na lida desta clínica. Olievenstein e Parada (2002) sublinham essa dimensão da paixão ao se referir a essa clínica, a qual chamam de clínica da intensidade. Em "O segredo dos seus olhos", filme de José Campanella (2009), há um personagem que traz a questão da paixão de um modo emblemático. Todos os dias o personagem Pablo vai ao bar e bebe desmesuradamente. Em uma cena em que o seu amigo vai procurá-lo, Pablo põe-se a falar da dimensão do pathos, da paixão. Pontua que o amigo reclama com ele por ir ao bar estragar a vida, mas que vai porque gosta, porque gosta de estar ali, de ficar bêbado, de brigar com alguém que o incomode. Vai por uma questão de paixão. É comum que atendamos pessoas com uso problemático de drogas e não lembremos nem do prazer envolvido, nem do que há de pathos, enquanto experiência de certa passividade, mas também enquanto dor e paixão. O personagem aponta para algo além da substância, um contexto, uma rede de sentidos. Assim como Olievenstein (1990), Zinberg (1984) pensou uma equação para a experiência com as drogas: droga, set e setting. As drogas são diferentes entre si: álcool e cocaína são distintas, maconha é diferente de crack, cachaça é diferente de cerveja. As drogas têm propriedades farmacológicas diferentes, efeitos esperados, efeitos colaterais e lugares sociais também distintos, algumas são lícitas, outras tornadas ilícitas. Cada sujeito que usa tem uma bagagem singular, uma história de vida, formas de se relacionar, uma 
cultura, inclusive familiar - um set. Finalmente o setting se refere ao ambiente em que se dá o uso, a frequência, o modo, o grupo, o contexto. Todos estes aspectos compõem a experiência dos mais variados usos de drogas, desde um uso recreativo até uma relação de dependência com uma substancia.

Uma clínica que alargue a sua mirada para além da dimensão química, olhando para a história do sujeito (e da sociedade) e para geografia, inclusive afetiva dos usos, pode também alargar as possibilidades de intervenção. Aproximamo-nos aqui da perspectiva da Redução de danos, além da sua pragmática enquanto política e estratégia, no que ela tem de uma ética do cuidado. A Redução de danos propõe intervir junto ao usuário, ainda que o mesmo não deseje ou não consiga interromper o uso de drogas. Subverte um refrão repetido ao modo de um cacoete nessa clínica, segundo o qual só é possível tratar se a pessoa quer parar de usar drogas. Aposta que é possível produzir cuidado a partir do lugar e do desejo do outro, muito próximo de algo que Paulo Freire (2005) defendia como um norte para a educação: uma dialogicidade verdadeira.

O revolucionário educador brasileiro entendia toda palavra verdadeira como práxis. Distinguia uma palavra verdadeira duma palavra inautêntica, oca, palavreria, blábláblá, verbalismo. Todos, para ele, temos direito a pronunciar a palavra verdadeira e por isso ela não pode ser privilégio de alguns homens. Adverte-nos generosamente: "Precisamente por isto, ninguém pode dizer a palavra verdadeira sozinho ou dizê-la para os outros, num ato de prescrição, com o qual rouba a palavra aos demais." (FREIRE, 2005, p. 90-91) A clínica da dependência química ou das toxicomanias está cheia destas palavras ditas sobre o outro, outro que comumente é silenciado ou posicionado na ordem do discurso num lugar de descrédito ou nulidade. 
Historicamente, os ditos loucos, hoje chamados portadores de transtornos mentais ou pessoas em sofrimento psíquico, também tiveram ao longo dos séculos (ainda tem) sua palavra posta num lugar de descrédito. Os movimentos de luta antimanicomial e a construção da Reforma Psiquiátrica atentam para outro posicionamento ante a palavra do "louco", que não apenas seus corpos não sejam mais aprisionados, mas que também não aprisionemos suas redes de sentidos.

Autonomia como saúde. Sendo que nunca é demais lembrar: "Ninguém é sujeito da autonomia de ninguém." (FREIRE, 1996, p. 107) Ampliar as possibilidades de existir, de escolher, de se construir no mundo, sem estar assujeitado. Saúde como potência de liberdade, como participação política, por que não? Saúde numa perspectiva alargada, também política, na cidade. Neste ponto da escrita, fica clara a conexão entre algumas lutas e movimentos inspiradores à clínica com pessoas que usam drogas, um tear entre Redução de Danos, Reforma Psiquiátrica e, sem dúvida, Reforma Sanitária. O imperativo ao tratamento destoa do ethos dessas lutas. Recolher das ruas não é saúde. Internar à força não é tratamento. Saúde não é dever. Os usuários não tem que se tratar. Os usuários podem se tratar - que o tratamento esteja ao lado de uma potência e não de uma obrigação. Saúde não é dever. É direito. No entanto, parece que tantos anos depois da Constituição Brasileira de 1988 e da Lei 8080 de 1990, estas palavras ainda pedem por ser práxis. Estas palavras, princípios do SUS, saúde como direito, universalidade, integralidade e equidade, pedem por não ser ocas, pedem por ser práxis! O paradigma da Redução de danos faz ressoar essas palavras em ação no mundo. Ao forçar os limites da clínica, esgarça as suas paredes conceituais, faz pontes com o SUS, com a luta antimanicomial, com a educação popular de Paulo Freire. Produz um desvio do olhar moralizante, frequentemente 
presente nos discursos e práticas clínicas dirigidas aos usuários de drogas. (SOUZA; TEDESCO, 2009)

Todavia, estamos em plena reedição de práticas higienistas e fascistas que contaminam as políticas sobre drogas. Na cidade limpa, pacificada, não cabe o que transborda, não cabe o doido, o usuário de drogas, o preto, o pobre, o estranho. Afirmar uma clínica que ouse ir além dos clichês, dos discursos maiores repetidos ao modo de verdades inquestionáveis, é uma atitude clínica inseparável de um posicionamento político. Afirmar uma resistência. Em contraponto ao "crack é possível vencer", quem sabe inventemos no miúdo da vida vivida, o é possível cuidar, junto, com. É possível? Talvez estejamos falando de resistências:

Mas sim resistências, no plural, que são casos únicos: possíveis, necessárias, improváveis, espontâneas, selvagens, solitárias, planejadas, arrastadas, violentas, irreconciliáveis, prontas ao compromisso, interessadas ou fadadas ao sacrifício; por definição, não podem existir a não ser no campo estratégico das relações de poder. (FOUCAULT, 2005b, p. 91)

Afirmar uma resistência, na clínica com essas pessoas, parece ser afirmar a radicalidade de uma escuta, uma escuta radical, freireanamente dizendo. Entre as narrativas dominantes, cavar brechas, brechas por onde passem dissonâncias, se teçam diferenças, possibilidades de ser e existir no mundo mais largas, mais livres. Não seria isto uma forma de saúde? 


\section{Referências}

CAMPANELLA, J. O segredo dos seus olhos; Filme. Buenos Aires, 2009.

CONTE, M. A Clínica Psicanalítica com toxicômanos: o corte e costura no enquadre institucional. Santa Cruz do Sul: EDUNISC, 2003.

DELEUZE, G.; GUATTARI, F. KAFKA. Para uma literatura menor. Lisboa: Assírio \& Alvim, 2002.

DRUMMOND DE ANDRADE, C. Alguma Poesia. São Paulo: Companhia das Letras, 2013.

FOUCAULT, M. História da Sexualidade 1: A vontade de saber. Rio de Janeiro: Edições Graal, 2005b.

2005a.

. A Ordem do Discurso. São Paulo: Edições Loyola,

FREIRE, P. Pedagogia da Autonomia. São Paulo: Paz \& Terra, 1996.

. Pedagogia do Oprimido. São Paulo: Paz \& Terra, 2005.

GOFFMAN, E. Estigma. Notas sobre a Manipulação da Identidade Deteriorada. Rio de Janeiro: LTC, 1988.

KHANTZIAN, E.J. The self-medication hypothesis of addictive disorderes: focus on heroin and cocaine dependence. American Journal of Psychiatry, v. 42, p. 1259-1264, 1985.

MILLER, W.R.; ROLLNICK, S. Entrevista Motivacional. Porto Alegre: ARTMED, 2001.

OLIEVENSTEIN, C. A Clínica do Toxicômano. A Falta da falta. Porto Alegre: Artes Médicas, 1990.

, C. ; PARADA, C. Droga, Adolescentes e

Sociedade. Lisboa: Instituto Piaget, 2002. 
PECHANSKY, F.; LUBORSKY, L. Abordagem psicodinâmica do paciente dependente químico. In: EIZIRIK, C. et al. Psicoterapia de Orientação Analítica. Fundamentos Teóricos e Clínicos. Porto Alegre: ARTMED, 2005. p. 778789.

PETUCO, D. O cuidado de pessoas que usam drogas: contribuições de uma redução de danos fecundada pela Educação Popular. In: SEMINÁRIO NACIONAL PSICOLOGIA E POLÍTICAS PÚBLICAS (5. : Brasília: 2011) Subjetividade, Cidadania e Políticas Públicas. Brasília: CFP, 2011.

PROCHASKA, J.O.; DICLEMENTI, C.C. Transtheorical therapy: Toward a more integrative modelo change. Psychoterapy: theory, Research, and Practice, v. 19, p. 276-288, 1982.

SOUZA, T.; TEDESCO, S. Territórios da Clínica: Redução de Danos e os novos percursos éticos para a clínica das drogas. In: CARVALHO, S.R.; FERIGATO, S.; BARROS, M. E. (orgs). Conexões: Saúde Coletiva e Políticas da Subjetividade. Rio de Janeiro: Ed. HUCITEC. 2009. p. 141-156.

TOROSSIAN, S. De qual cura falamos? Tóxicos e Manias. Revista da Associação Psicanalítica de Porto Alegre, n. 26, p. 9-15, 1995.

ZINBERG, N.E. Drug, set and setting. New Haven: Yale University Press, 1984. 


\section{Redução de Danos: das técnicas à ética do cuidado}

Reduzir danos e riscos. Minimizá-los, até mesmo eliminá-los. Problemas considerados como agravos à saúde, bem como as definições de seus contornos e a construção de estratégias para reduzi-los ou eliminá-los, modificaramse profundamente ao longo do tempo. Dos gregos até hoje, passando por toda a Idade Média e Renascimento, atravessando a modernidade e chegando até os dias atuais, a visão que temos a respeito dos usos de drogas e as formas que construímos para lidar com este tema a partir de dispositivos sanitários têm uma história que ainda precisa ser contada.

Contar esta história é trabalho de uma vida, não de um texto. O objetivo aqui é mais modesto: problematizar uma parte da longa história das políticas públicas e dos cuidados em saúde dirigidos a pessoas que usam álcool e outras drogas: a Redução de Danos. Organizo esta história em "três nascimentos": o primeiro na Inglaterra, o segundo na Holanda, e o terceiro no Brasil, como ética do cuidado e clínica ampliada. 


\section{O Primeiro Nascimento da Redução de Danos}

Em 1924, os ingleses viam-se às voltas com os impactos da I Guerra Mundial. No campo da saúde, uma das questões era o aumento do uso problemático de morfina e heroína. As tentativas de suspensão do uso, mesmo em ambiente hospitalar, eram ineficientes, já que a severa síndrome de abstinência decorrente da brusca retirada de opiáceos impedia a completa adesão dos pacientes aos tratamentos então vigentes.

Neste contexto, formou-se um grupo de trabalho composto por oito especialistas. Depois de dois anos, o comitê concluiu por uma série de recomendações para o tratamento de pessoas com dependência de opiáceos. 0 Relatório Rolleston (UNITED KINGDOM, 1926), como ficou conhecido, recomendava a administração controlada de morfina e heroína para diminuir o sofrimento decorrente da brusca retirada destas drogas, prática comum à época, e que em casos mais extremos pode levar até mesmo à morte.

Foi uma revolução no tratamento de pessoas com uso problemático de álcool e outras drogas, baseados unicamente na abstinência. A realidade, contudo, impunha limites a esta abordagem. Inaugurava-se a "terapia de substituição", primeira das estratégias de Redução de Danos.

Com o tempo, este primeiro nascimento desdobrouse em outras técnicas específicas. Uma prática amplamente difundida é a oferta de metadona para dependentes de heroína e morfina. Mais segura que outros opiácios, a metadona permite ao usuário suportar melhor os efeitos da abstinência. 


\section{O Segundo Nascimento da Redução de Danos}

Em 1926, os ingleses viviam um contexto de pós guerra, com um importante aumento no uso de heroína e morfina. Já o contexto do segundo nascimento da Redução de Danos está relacionado a um conjunto muito específico de eventos que tiveram lugar na cidade de Amsterdã, Holanda, no início dos anos 80:

Em 1984, motivado pelo fato de uma farmácia localizada no centro da cidade ter decidido interromper a venda de apetrechos de injeção para usuários de drogas injetáveis e do medo de uma possível epidemia de Hepatite B, a "União Junkie", uma associação de ex-usuários de drogas e usuários de drogas em atividade preocupada com o papel dos usuários de drogas na sociedade e seus direitos civis, lançou a ideia de distribuição livre de seringas para usuários de drogas. (VERSTER, 1998, p. 118)

Articulação de medos: medo dos funcionários de uma farmácia em atender usuários de drogas; medo que tinham estes próprios usuários diante de uma possível epidemia de hepatites virais. No entanto, é possível supor que outras cidades do mundo convivessem com estes mesmos medos; por que então é justamente Amsterdã a primeira cidade do mundo a implantar uma tecnologia com estas características?

Estamos falando de um país com uma sólida tradição de respeito às liberdades individuais; além disso, com uma legislação que prevê a descriminalização do uso de drogas e o privilégio da saúde como foco da ação estatal. A qualidade dos serviços era tamanha que em um determinado momento foi necessário vetar o tratamento para estrangeiros (exceção para as eventuais emergências), 
ajudando-os a buscar tratamento em seus países. (VERSTER, 1998)

Aoacontecimento biológico, soma-se o acontecimento político e cultural da Aids. Os modos de infecção exigem mudanças na saúde pública. As primeiras estratégias para 0 enfrentamento da epidemia, calcadas na noção de "grupo de risco", mostraram-se simultaneamente ineficientes e perversas: ineficientes porque incapazes de realizar a tarefa a qual se propunham; perversas pela produção de estigma e preconceito, ao considerar determinadas populações como culpadas pela doença.

A questão é menos a droga, e muito mais o meio de utilização. Não se trata de ajudar as pessoas a parar com o uso ou diminuir o sofrimento relacionado à abstinência, mas de evitar riscos relacionados às formas de uso. Um deslocamento que se efetiva em uma possibilidade de ampliação do olhar e da intervenção em saúde. Estratégia construída fora do campo das drogas, mas que a ele retorna, produzindo tensões.

\section{O Terceiro Nascimento da Redução de Danos}

Em 1989, Santos era a cidade brasileira com maior número de casos de Aids, muitos decorrentes do compartilhamento de seringas. Além disto, a cidade contava com gestores que reuniam capacidade técnica e coragem política, antes mesmo da aprovação das leis de Sistema Único de Saúde e da Reforma Psiquiátrica brasileira.

Com um grupo técnico qualificado e comprometido politicamente, a coragem de mudar se expressou em ousadias que inspiraram toda uma geração de sanitaristas e militantes do SUS: intervenção e fechamento da Casa de 
Saúde Anchieta e criação de estratégias de base territorial para o acompanhamento de pessoas em sofrimento mental; criação do primeiro centro de referência em Aids; abertura de um núcleo de atenção para usuários de drogas... E muito mais. (CAMPOS; HENRIQUES, 1997)

Mas, e a Redução de Danos?

Em setembro de 1989, organizamos o primeiro Seminário de Aids do Município de Santos, durante o qual apresentamos a boa nova: o Programa de Aids do Município iria começar a troca de seringas nos próximos dias. Nesse momento, nosso sonho começou a se tornar um pesadelo. Matérias nos jornais, revistas, rádios e TVs, debates na cidade, ameaçadas de prisão, etc. Ao final, foi estabelecido um acordo, constatando-se que naquele momento tínhamos de recuar. (BUENO, 1998, p. 163)

A cidade, que sustentava experiências inovadoras na área da saúde, viu seu programa de troca de seringas paralisado pelo conservadorismo tacanho, no momento em que tal iniciativa era imprescindível. Quantas mortes, quanta dor. Medo e preconceito sempre mataram mais que qualquer vírus. A intransigência de setores conservadores não bloqueou apenas as trocas de seringas em Santos, mas atrasou a implementação da Redução de Danos em todo o país. Foram seis anos até que Salvador conseguisse realizar, de modo aberto, aquilo que os santistas foram obrigados a concretizar de modo clandestino ${ }^{1}$.

Os soteropolitanos lograram êxito onde os santistas falharam, provavelmente porque a experiência baiana nasceu na academia, à qual se reconhece a tarefa de estudar tecnologias inovadoras. Em 1994, Centro de

1 Trocas de seringas e oferta de hipoclorito de sódio davam-se clandestinamente em alguns lugares. A Bahia foi a primeira cidade a realizar abertamente ações deste tipo. (BUENO, 1998) 
Estudos e Terapia de Abuso de Drogas (CETAD), um serviço de extensão da Faculdade de Medicina da Universidade Federal da Bahia, recebe recursos da então Coordenação Nacional de DST/Aids; será a partir deste financiamento que o CETAD conseguirá tornar realidade, em 1995, o primeiro programa de troca de seringas do Brasil.

Com os anos, as experiências de Redução de Danos se multiplicaram e diversificaram. Neste sentido, os encontros nacionais de redutores de danos emergiram como um verdadeiro caleidoscópio de experiências. Ocorrendo com alguma periodicidade, estes encontros permitiram - ainda permitem - o intercâmbio entre pessoas e coletivos que se dedicavam ao desenvolvimento de ações de Redução de Danos junto a usuários de drogas.

Nestes encontros, percebia-se que os redutores faziam mais que trocar seringas. Garantiam acesso para o tratamento de problemas que iam muito além das questões objetivamente relacionadas ao uso de drogas. Às pessoas vivendo com Aids, garantiam adesão ao tratamento. Buscavam articulações intersetoriais que aproximavam usuários de drogas de políticas de assistência social e educação. Além disto, a incorporação de usuários como redutores trazia vozes que até então só encontravam enquadramento como sintoma, prova judicial ou confissão. Na síntese de Domiciano Siqueira:

Ao considerarmos que o caminho do crime é a cadeia, do doente o hospital e do pecador o inferno, percebemos que se mudarmos o contexto mudaremos também o caminho trilhado por estas pessoas sem necessariamente mexer com a individualidade e com as escolhas pessoais. (SIQUEIRA, 2006, p. 14)

Este deslocamento para além do sintoma, do pecado ou do crime, permite novas palavras, novos olhares e novas 
práticas. Torna-se possível ver o que antes não era visto, dizer o que antes não era dito, fazer o que antes não era feito. Domiciano Siqueira costumava dizer que se uma pessoa fosse capaz de realizar algo tão radical quanto oferecer uma seringa para que alguém injetasse cocaína em suas veias, ela seria capaz de realizar qualquer coisa. E estas novidades expressavam-se em formas por vezes muito sutis, de modo que talvez fosse necessário ajudar às pessoas a perceber nuances, delicadas filigranas de uma nova clínica que se inventava, em ato.

\section{Três Cenas da Redução de Danos no Brasil}

Na primeira cena, vê-se uma ruela coberta de lixo e com muitos barracos. Em um deles, uma redutora de danos recolhe seringas usadas, sob o olhar do dono da casa e de um colega de trabalho. Em um determinado momento, o anfitrião comenta que precisou reutilizar várias daquelas seringas. Os redutores o interrogam, explicando que $o$ correto é usar uma seringa para cada dose de cocaína. Constrangido, o morador explica que sabe disto, mas que infelizmente não havia seringas suficientes.

Percebendo o constrangimento, a redutora demonstra, em ato, que o trabalho dos redutores sempre ultrapassou o mero preventivismo. Senta-se ao lado do dono da casa e explica: "Pra nós, que já estamos contaminados, nós nos contaminamos cada vez mais.". Ao que o anfitrião responde: "É como a médica me falou: se parar com os remédios, no momento em que recomeçar, a situação já vai estar pior...".

Na segunda cena, dois redutores de danos encontram um usuário do programa saindo do hospital. Pessoa em situação de rua e vivendo com Aids, a estabilização de 
um quadro de tuberculose justificava a alta, mas não tranquilizava os redutores, que tentavam convencê-lo a ir para um abrigo. O usuário odiava as unidades de acolhimento da política de assistência social. Era um hippie irrecuperável, e não tinha a menor vontade de adaptarse às regras daquele tipo de serviço. Os redutores não conseguiam esconder a empatia, mas o frio rigoroso e as chuvas inspiravam preocupação.

Foi quando um dos redutores lembrou que havia sido chamado para conduzir uma oficina em uma squat ${ }^{2}$, poucos dias antes. Ainda receoso se aquele ex-hippie tinha simpatia por punks, arriscou: contou-lhe sobre o espaço, dizendo que não havia garantia de que seria aceito no local. Afinal, não se tratava de um serviço público, mas de uma ocupação clandestina! As ponderações, entretanto, pareciam funcionar ao contrário, incentivando-o ainda mais a confiar naquela estratégia maluca.

Naquele mesmo fim de semana, um dos redutores voltou à squat para uma atividade com um zapatista mexicano. Demorou um pouco para reconhecer aquele homem mais velho, cabelos raspados em estilo moicano, roupas customizadas; mais um punk entre punks, mais um anarquista entre anarquistas. Parecia feliz.

A terceira cena ocorreu no 5o Encontro Nacional de Redutores de Danos, em 2004. Naquele momento, o debate que mobilizava o movimento dizia respeito ao gradual esvaziamento das caixas coletoras de seringas. Por todo o Brasil (em algumas cidades mais cedo, em outras mais tarde), as pessoas para as quais estávamos acostumados

2 Enquanto uma ocupação do Movimento de Luta pela Moradia (MLM) busca garantir a posse de uma propriedade para aqueles que necessitam de um lugar para morar, uma squat caracteriza-se como uma "zona autônoma temporária" (BEY, s.d.), e pode destinar-se não apenas à moradia, parecendo às vezes com uma espécie de centro cultural independente. 
a dirigir nossas ações substituíam a cocaína injetável pelo crack.

Em face deste fenômeno, alguns redutores anteviam o fim dos recursos para Redução de Danos. Afinal, o crack não trazia nenhuma relação direta com a infeç̧ão pelo HIV. Claro que havia o sexo pela droga, e uma ligação entre compartilhamento de cachimbos e contágio que se mostrava muito mais teórica do que concreta, mas nada que justificasse investimentos por parte do Ministério da Saúde ou Banco Mundial.

Seria mesmo o fim da Redução de Danos no Brasil? Para a maioria, não. Sempre haviam feito mais que trocar seringas. De modo mais enfático: os redutores brasileiros nunca se limitaram às trocas de seringas ou à prevenção e o tratamento da Aids. Percebiam que eram protagonistas de uma pequena revolução: a invenção de uma nova ética do cuidado dirigido a pessoas que usam álcool e outras drogas.

\section{Redução de Danos - Uma Nova Ética do Cuidado}

Esta compreensão não surgia naquele momento; já estava presente na política do Ministério da Saúde para o assunto. (BRASIL. Ministério da Saúde. Secretaria de Atenção à Saúde, 2004) Aparecia também no encontro entre as reformas sanitária e psiquiátrica e a Educação Popular, remontando nossa tradição antropofágica de apropriar-se de invenções estrangeiras - como a Redução de Danos reinventando-as e Ihes conferindo características muito próprias.

A Redução de Danos esgarça princípios do SUS e da Reforma Psiquiátrica. (PETUCO, 2011) Com Espinoza, entretanto, podemos dizer que o cuidado de pessoas que 
usam álcool e outras drogas foi abalado pela Redução de Danos, assim como a Redução de Danos foi abalada pelas citadas reformas e pela Educação Popular. Se Arouca questionasse o preventivismo na troca de seringas, descobriria que os redutores jamais foram "entregadores de seringas" 3 , enquanto Freire perceberia que a pedagogia dos redutores de danos em hipótese alguma poderia ser definida como "bancária"4.

Fruto de uma roda de conversa realizada em 1982, "Pacientes impacientes" aborda cinco princípios que Paulo Freire considerava fundamentais à Educação: saber ouvir; desmontar a visão mágica; aprender/estar com o outro; assumir a ingenuidade dos educandos; viver pacientemente impaciente. (FREIRE, 2007) Este texto oferece as bases do que se poderia chamar de "clínica freireana" (PETUCO, 2011), que se materializa de diferentes formas. Uma clínica que permite ouvir para além dos discursos autorizados:

Quando nós abrimos à experiência do outro, torna-se possível ouvir para além dos discursos normalmente autorizados. No caso das drogas, os discursos vitoriosos e os discursos derrotados. Por vitoriosos, entendem-se os discursos daqueles que venceram as drogas, e que se apresentam como exemplo; o outro lado da mesma moeda, os derrotados são aqueles que se apresentam de modo subserviente, humilhados, aceitando qualquer coisa de modo subalterno e sem questionamentos. (PETUCO, 2011, p. 25)

Usuários de drogas sabem que discursos não autorizados podem dificultar seu acolhimento nos serviços

3 Entre redutores de danos, ser chamado de "entregador de seringas" é uma ofensa.

4 Paulo Freire $(2005$, p. 66) definia assim a educação que faz "depósitos" na cabeça do educando. 
de saúde. Diante disto, a Redução de Danos propõe uma clínica radicalmente aberta, ampliando a noção de acolhimento para além da mera porta aberta, propondo um "ouvido aberto" para o que não gostaríamos de ouvir. Esta "clínica freireana" não é privilégio de redutores de danos: ela pode e deve ser efetivada por todo e qualquer trabalhador da saúde, da educação, da assistência social...

Ampliar a escuta, ampliar a clínica. A Clínica Ampliada caracteriza-se pela: compreensão ampla dos processos de saúde-doença; partilha do cuidado; articulação intersetorial; ampliação do repertório clínico para além do modelo técnico-assistencial; compromisso ético profundo. (BRASIL. Ministério da Saúde. Secretaria Executiva. Núcleo Técnico da Política Nacional de Humanização, 2004, p. 8-9) Afinada com tal perspectiva, a Redução de Danos propõe não apenas a escuta das vozes interditas, como a ampliação das práticas e da população assistida. Afinal, quando nos restringimos à abstinência, anulamos a possibilidade de promoção de saúde para pessoas que não conseguem ou não desejam tal objetivo. Além disto, a ampliação do foco permite atender demandas para além dos problemas relacionados diretamente ao uso de drogas em si mesmo.

Ampliação que também diz respeito a tripla dimensão territorial: lugares (praças, matagais, boates, barracos, becos...); tempos (madrugada, entardecer, estações e períodos do ano...); e uma dimensão existencial, a apontar que de nada vale chegar aos locais nos horários certos, se não for possível reconhecer o território em seus fluxos, códigos e dinâmicas particulares. Espaço, tempo e afeto: as três dimensões do território concebido na experiência brasileira da Redução de Danos. (PETUCO, 2013, p. 53-55)

Esta ampliação permite operar o território como ferramenta de trabalho. Em suas caminhadas, os redutores produzem articulações, não apenas intersetoriais, como de 
redes informais. A história partilhada neste artigo, em que um redutor vale-se de uma squat, é apenas um de infinitos relatos semelhantes, em que atores e instituições pouco convencionais são articulados na produção de projetos terapêuticos singularíssimos.

Por fim, é importante que se diga que este olhar ampliado não brota de mentes iluminadas, forjadas nas experiências de vida de trabalhadores que vivem ou viveram as vicissitudes da criminalização. Uma postura humilde, desprovida de receitas prontas, desconfiada de teorias que desenham os usuários de drogas a partir de perfis dados, é mais importante do que qualquer conhecimento técnico, teórico ou empírico. Não que as experiências não sejam importantes! Elas são, é muito, e é justamente por isto que é preciso manter-se sempre aberto, para que novas experiências permitam a construção de novos saberes. Ou dito de outra maneira, nas palavras de uma grande redutora de danos:

Eu sei muito pouco. Mas tenho a meu favor tudo o que não sei e - por ser um campo virgem - está livre de preconceitos. Tudo o que não sei é a minha parte maior e melhor: é a minha largueza. É com ela que eu compreenderia tudo. Tudo o que não sei é que constitui a minha verdade. (LISPECTOR, 1999, p. 415) 


\section{Conclusão}

Este artigo encerra a discussão em torno dos caminhos que a Redução de...

- Pare! Não prossiga! Como pode colocar o ponto final quando você não apenas não diminuiu minhas dúvidas, como as ampliou! Em momento algum você diz quais seriam as técnicas de Redução de Danos para as demandas atuais em CAPSad, Atenção Primária, assistência social, escolas, ou mesmo nos consultórios privados. Não falou praticamente nada sobre as drogas e seus usos, muito menos sobre crack e álcool, as substâncias que mais preocupam. Apontou desafios éticos, é verdade, mas teceu fios precários entre teoria e prática. Os exemplos tornaram a discussão ainda mais nebulosa. Por isso, nem pense em acabar agora!

- Desculpe, eu não queria produzir angústia. Se optei pelo caminho mais complicado, não foi para parecer sofisticado ou complicar sua vida, mas apenas para demonstrar a quão ampla pode ser a Redução de Danos. Não queria uma lista fechada de estratégias, mas indicadores que permitissem avaliar a prática cotidiana, interrogando-a em sua própria existência, no que produz ou reproduz...

- Mas, qual o problema em afirmar uma listagem mínima de possibilidades concretas a serem implantadas em diferentes espaços? Por que não explicar em detalhes como se pode fazer Redução de Danos em diferentes espaços? Este tal "terceiro nascimento" de que você fala parece tão insubstancial, tão diáfano, que eu chego a me perguntar se isto realmente existe. Você pode ser um pouco mais claro neste sentido?

- Talvez, mas não tanto quanto você exige. Sinceramente, achei que as cenas escolhidas dariam conta. Ali nós vimos que a Redução de Danos jamais se restringiu às trocas de seringas, e que seu olhar sempre foi abrangente, 
indo além do uso de drogas. Construindo estratégias com pessoas que não conseguem ou não querem parar de usar drogas, os redutores produziram um deslocamento provocador, que desestabilizou práticas arraigadas. Vimos que a "clínica" da Redução de Danos foi desde sempre ampliada, seja em sua compreensão, ou nos singularíssimos projetos terapêuticos construídos. Sendo assim, parece-me que se eu tivesse feito da maneira como você me pede, eu teria produzido um texto incapaz de atingir aos objetivos deste artigo.

- E você poderia dizer, no fim das contas, que objetivos são estes?

- Redutores não decoram fórmulas prontas. Se assim fizerem, serão meros "trocadores de seringas", mesmo que não as ofereçam em seu cotidiano. $O$ diferencial não reside em um cardápio de estratégias, mas na capacidade de operar de modo não prescritivo, não colocando a abstinência como único objetivo. Esta Redução de Danos de "terceira geração" da qual falei apresenta-se como ponto de partida, compromisso ético, estético e político, e não como um guia preciso, roteiro fechado, receita de bolo, nem como uma partitura de ações sanitárias, mas como um chamado ao compromisso. Não pretendi tornar as coisas mais fáceis. 0 que proponho, enfim, é um compromisso. Assumi-lo não facilita em nada o trabalho: apenas o torna mais potente. 


\section{Referências}

BEY, Hakim. Zona Autônoma Temporária. s.l. Coletivo Sabotagem, s.d.

BRASIL. Ministério da Saúde. Secretaria de Atenção à Saúde. A política do Ministério da Saúde para atenção integral a usuários de álcool e outras drogas. Brasília: Ministério da Saúde, 2004.

- Ministério da Saúde. Secretaria Executiva. Núcleo Técnico da Política Nacional de Humanização. Clínica Ampliada. Brasília: Ministério da Saúde, 2004.

BUENO, Regina. Estratégias de Redução de Danos em Santos, SP. In: BASTOS, Francisco Inácio; MESQUITA, Fábio; MARQUES, Luiz Fernando. Troca de seringas: ciência, debate e saúde pública. Brasília: Coordenação Nacional de DST e Aids, 1998. p. 163-169.

CAMPOS, Florianita Coelho Braga; HENRIQUES, Cláudio Maierovitch Pessanha (orgs.). Contra a maré à beira-mar: a experiência do SUS em Santos. São Paulo: Hucitec, 1997.

FREIRE, Paulo. Pacientes impacientes. In: BRASIL. Ministério da Saúde. Secretaria de Gestão Estratégica e Participativa. Departamento de Apoio à Gestão Participativa. Caderno de Educação Popular e Saúde. Brasília: Ministério da Saúde, 2007. p. 32-45.

Terra, 2005.

. Pedagogia do oprimido. Rio de Janeiro: Paz e

LISPECTOR, Clarice. A descoberta do mundo. Rio de Janeiro: Rocco, 1999.

PETUCO, Dênis Roberto da Silva. Campanhas de prevenção e o jovem usuário de crack. In: FRAGA, Paulo Cesar Pontes; 
IULIANELLI, Jorge Atilio Silva. O tempo real dos jovens: juventude como experiência acumulada. Rio de Janeiro: Letra Capital, 2013. p. 50-67.

- Redução de danos. In: CONSELHO REGIONAL DE PSICOLOGIA-SP. Álcool e outras drogas. São Paulo: CRPSP, 2011. p. 127-137.

SIQUEIRA, Domiciano. $O$ contexto e o conceito. In:SIQUEIRA, Domiciano (org.). Mal(dito) cidadão numa sociedade com drogas. São Paulo: Edição independente, 2006. p. 13-17.

UNITED KINGDOM. The Rolleston Report, conclusions and recommendations: The circumstances in which morphine and heroin may legitimately be administered to addicts. 1926.

VERSTER, Annette. Os programas de troca de seringas em Amsterdã. In: BASTOS, Francisco Inácio; MESQUITA, Fábio; MARQUES, Luiz Fernando. Troca de seringas: ciência, debate e saúde pública. Brasília: Coordenação Nacional de DST e Aids, 1998. p. 115-124. 


\section{Experiência e cuidado: a experimentação como via de composição entre Redução de Danos e Atenção Básica}

Rafael Dias e lacã Macerata "Experimentar o experimental" (Waly Salomão)

Introdução

Muito recentemente vimos ganhar relevo 0 problema do crack nas grandes cidades brasileiras, com o envolvimento da mídia e de múltiplas políticas de Estado. A partir deste problema, já discutido em artigo anterior (MACERATA; DIAS; PASSOS, 2014), buscamos colocar em análise algumas práticas dessas políticas de intervenção junto aos usuários de crack, sob o argumento de cuidado com os mesmos. Assim, realizamos uma análise da política de recolhimento compulsório na cidade do Rio de Janeiro. Há um modo hegemônico de lidar com a questão do uso das drogas na atualidade e que está na base do sentido de tal política: o que chamamos de paradigma da abstinência e paradigma proibicionista. (DIAS, 2013)

Neste paradigma, ligado à conhecida guerra às drogas, vimos que há a sustentação de um antagonismo ${ }^{1}$,

1 Esse antagonismo também atravessa as práticas da saúde impedindo 
definido pela eliminação, não só em relação às substâncias tornadas ilegais, mas principalmente a um tipo de experiência considerada marginal na cidade ${ }^{2}$. Experiências que chamamos fora da ordem: moradores de rua, loucos, usuários de drogas e muitos outros que tem um modo de vida que escapa do ordenamento desejado pela sociedade capitalista moderna. De modo que nessas intervenções guiadas pela lógica da abstinência, trata-se de excluir as experiências fora da ordem do plano de relação no espaço urbano: seja por eliminação direta, seja por uma reeducação moral, clausura e isolamento. O paradigma proibicionista, dessa maneira, veicula práticas higienistas de limpeza social ligadas ao racismo e a ideia de pureza.

A esta estratégia bélica, contrapomos a Redução de Danos - RD, como paradigma e estratégia, que faz um movimento muito distinto: a RD, em nosso entendimento, busca incluir e legitimar as experiências singulares e concretas dos sujeitos e coletivos, veiculando uma ética de acolhimento e composição com estes modos de vida considerados anormais. No trabalho anterior, já citado, concluímos que a RD realiza um cuidado das experiências singulares dos sujeitos, sem relacioná-las a nenhum tipo de ordem estática exterior, mas buscando a ampliação da saúde e da vida a partir de suas condições concretas. Deste modo, cuidar da experiência é acolhê-la na maneira como ela se apresenta, buscando em suas condições materiais de produção de subjetividade, as potencialidades para a criação de outros modos (normas) de vida, de outras normatividades. (CANGUILHEM, 1982)

os profissionais de produzir vínculos e o contato dos usuários com os diversos dispositivos do campo da assistência e da saúde. Dessa maneira, as políticasantidrogas sustentam uma postura de contraposição, dificultando a composição de redes e o caráter conectivo do cuidado. 2 Bóndia (2002) considera que a etimologia da palavra experiência contém inseparavelmente a dimensão de travessia e perigo. 
Toda intervenção veicula uma ética e uma política. Ela é sempre produzida em um campo político a partir de um certo posicionamento ético. Desta forma, em meio a um campo político hegemonicamente de guerra àquilo que está fora da ordem, como os profissionais de saúde da atenção básica vão se posicionar no problema relativo às drogas? Que tipo de ética e de política se produzem em meio às práticas na saúde pública, quando ela se encontra com essas experiências?

Entendemos a Redução de Danos como um paradigma clínico, ético e político para a questão das drogas no contemporâneo, alternativo ao paradigma hegemônico. Contudo, se temos o paradigma da abstinência como dominante nos campos de saber e intervenção que se encarregam do problema das drogas, a saúde pública não está livre desta dominação: também no campo da saúde, as drogas, principalmente as etiquetadas como ilícitas, são tratadas como problema moral, e também as experiências singulares dos sujeitos são excluídas em nome de normas transcendentes.

Se para as intervenções com os usuários de drogas propomos anteriormente um cuidado da experiência, para isso, é preciso que também as práticas na saúde sejam trabalhadas, transformadas. É preciso cuidar da experiência do usuário, mas para isso, para que os profissionais de saúde possam experimentar o cuidado, é preciso cuidar da experiência do cuidado dos profissionais de saúde, é preciso criar condições para que o cuidado aconteça. Esse movimento reflexivo, agir sobre sua ação, é um dos componentes necessários à operação de cuidado: cuidar da experiência do outro tem como pressuposto cuidar de sua experiência de cuidado.

Ao atrelarmos o cuidado à inclusão da experiência, trabalhamos com uma ideia de cuidado que 
necessariamente é sempre construída localmente, que se faz por um determinado modo de conhecer o sujeito e seu território de relações. Pois assim sendo, afirmamos que, na saúde pública, há condições para construirmos um efetivo cuidado, que se vincule a outra ética e a outra política que não àquelas do fracassado, mas ainda não superado, paradigma proibicionista. Vamos entender que estas condições existem na política de Atenção Básica ( $A B)$, na medida em que ela possa se articular com a Redução de Danos (RD).

Este é o tema que queremos tratar neste capítulo: a possibilidade da realização de um cuidado da experiência com as drogas na Atenção Básica, através da criação de condições para a experiência do cuidado. A maneira como queremos propor isso é situando o surgimento da Redução de Danos no campo problemático das drogas, tomando os elementos que irrompem com este surgimento, como força motora que produz, para o campo das políticas públicas em geral, um paradigma de cuidado que tem metodologiase diretrizes que podem ser articuladas às práticas de Atenção Básica. Estas metodologias, vamos afirmar, criam condições técnico-políticas para que o profissional possa experimentar o cuidado, o que é condição para que ele possa cuidar da experiência do outro e de si mesmo.

\section{Breves definições dos conceitos operativos de experiência e cuidado}

Seguimos Silva et al. (2010) quando estes definem dois sentidos para experiência: um primeiro é a experiência como história de vida - aquilo que pode ser falado sobre uma vivência pregressa, a história de vida de uma pessoa, que remete ao vivido. O segundo é o sentido afetivo da 
experiência: a experiência como ato de "experenciar" determinado momento presente, que remete a um "vivendo". Exemplo: a experiência com o uso de crack de uma pessoa comporta sua história de uso, e também aquilo que ela vivencia em ato, ou melhor, o como ela vivencia o uso da droga. Esse segundo sentido da experiência remete a uma experiência de natureza afetiva, quer dizer, não passa somente pela palavra, pelo que pode ser pensado e dito, mas por um tipo de vivência qualitativa radical. Pois é com estes dois sentidos de experiência que o cuidado da RD trabalha: construindo as estratégias a partir da história singular do sujeito, legitimando-a, acolhendo-a para poder produzir outro tipo de história e considerando também sua experiência subjetiva com a droga, ou seja, a maneira com que cada um se relaciona com a droga. A RD, assim, não trabalha com a droga como categoria geral, como se ela fosse a mesma droga para toda pessoa, mas trabalha com o lugar singular que uma droga tem na vida de uma pessoa: na sua história de vida e no seu modo de viver.

Já o cuidado é um termo mais abrangente do que um procedimento de cuidado, uma ação de um agente cuidador: cuidado aqui é entendido como uma relação, que aparece como efeito de práticas. Certamente a relação de cuidado depende de ações de cuidado de um cuidador, mas não é garantida somente por elas. Por exemplo: no caso da saúde, o cuidado envolve uma ação de um profissional de saúde, mas também o cuidado do usuário para consigo mesmo. Assim, o cuidado é constituído como efeito de uma rede de práticas de diversos atores e instituições envolvidas em um certo ambiente de cuidado ${ }^{3}$.

3 Sobre uma definição de ambiente de cuidado, ver neste mesmo volume, o capítulo Vulnerabilidades do usuário e vulnerabilidades da atenção: apontamentos iniciais para uma clínica de território na Atenção. Básica (MACERATA, 2014) 


\section{A RD: paradigma ético na política de atenção integral para usuários de álcool e outras drogas}

É preciso dizer que o paradigma da abstinência vai além de um direcionamento clínico compartilhado e eticamente referenciado no sentido da interrupção do uso de drogas. Passos e Souza (2011) esclarecem que:

Por paradigma da abstinência entendemos uma rede de instituições que define uma governabilidade das políticas de drogas e que se exerce de forma coercitiva na medida em que faz da abstinência a única direção de tratamento possível, submetendo o campo da saúde ao poder jurídico, psiquiátrico e religioso. (PASSOS; SOUZA, 2011, p. 157)

A abstinência e a RD são dois paradigmas contrastantes no campo das políticas públicas sobre álcool e outras drogas. O paradigma da abstinência está relacionado à política antidrogas, é o método de abordagem mais tradicional e diz respeito a um conjunto de práticas hegemônicas. Na atualidade as denominadas comunidades terapêuticas (CT) são o dispositivo onde esse paradigma é mais visível. O preocupante é que as CT difundem, para efetivar o seu "método", práticas de sequestro e tutela, que violam a autonomia e os direitos humanos dos usuários de álcool e outras drogas.

O paradigma da RD considera a abstinência como um caminho possível de ser trilhado, a partir da análise da singularidade de cada caso. No entanto, essa não é uma condição essencial para o tratamento, nem um objetivo em si mesmo para a produção de cuidado. O círculo vicioso das "recaídas" e do discurso moral associado a elas não fazem sentido para a prática da RD. A Política de Atenção Integral para os Usuários de Álcool e outras Drogas considera que a 
abstinência não pode ser o único objetivo a ser alcançado. As práticas de cuidado devem acolher sem julgamento os diversos modos de viver. (BRASIL. Ministério da Saúde. Secretaria Executiva. Secretaria de Atenção à Saúde. CNDST/AIDS, 2003)

A RD surge como uma prática calcada na experiência. É por uma proximidade com a experiência de uso de drogas, que são desenvolvidas as práticas de cuidado: indo aos territórios de uso, construindo estratégias a partir do conhecimento deste ambiente e das suas singularidades, produzindo vínculo, ofertando insumos. Em síntese, ampliando e experimentando novas estratégias de cuidado diante da multiplicidade das situações concretas. Não à toa, os primeiros redutores de danos eram usuários e pessoas que conheciam muito bem os territórios onde atuavam, com seus atalhos, obstáculos e pedras no caminho.

Ela nasce, portanto, numa conjunção de campos de experiência: uso de drogas, práticas de saúde, assistência social, educação e cultura. De modo que para a construção da RD foi necessária uma experimentação. Afirmamos, ainda, que a própria RD deve guardar, em cada ato, a todo momento, uma dimensão de experimental.

Essa dimensão experimental faz parte dos primórdios da RD no Brasil, na cidade de Santos, em 1989, quando trabalhadores de saúde e gestores ousaram desenvolver estratégias de RD para usuários de Drogas Injetáveis (UDIs). Nessa experiência, identificamos um importante marco histórico e político do processo da RD no Brasil e de experimentação no campo da saúde pública articulada com o processo da Reforma Psiquiátrica Brasileira.

Em seu começo, as ações de RD se desenvolveram em aliança com um setor democrático que, mesmo dentro da máquina estatal, mais precisamente na Coordenação Nacional de DST e Aids do Ministério da Saúde e em 
Secretarias de estado, resistiam de modo ético às políticas repressivas e violentas que constrangiam práticas de cuidado entre usuários de drogas injetáveis. Isso tornou possível a realização de práticas de RD em outras cidades brasileiras, destacando as ações de pesquisa e intervenção na cidade de Salvador, a partir de 1994, desenvolvidas pela Universidade Federal da Bahia, de modo pioneiro e duradouro.

A RD surge como uma estratégia de prevenção em saúde, mas com a ampliação dos atores envolvidos (usuários de drogas, movimentos sociais LGBT, trabalhadores de saúde, etc) nessas práticas, suas ações se politizam e questionam a tradição preventista baseada na gestão dos ricos. Desse modo, a RD afirma-se como um paradigma interessado pelas práticas de cuidado e guiadas pelo debate da clínica ampliada, da autonomia e dos direitos humanos. No entanto, os aspectos sócio-sanitários e preventivos precisam ser continuamente problematizados para que não ensejem práticas de vigilância de grupos sociais considerados vulneráveis ou mesmo "perigosos". Atentativa de controlar, com o auxílio de variáveis estatísticas, fatores consideradas de risco pode ensejar ações de tutela e estigmatização, ao identificar que determinados indivíduos ou grupos como um risco social ou sanitário.

Esse é precisamente a opção proposta pelo paradigma proibicionista que através de "campanhas de prevenção" ao uso de drogas veicula mensagens de pânico moral. Essas medidas são um obstáculo para o desenvolvimento de políticas públicas intersetoriais que respeitem a diversidade e os direitos humanos. 
Composições experimentais entre Redução de Danos e Atenção Básica: acolhimento e produção de diferença através do cuidado da experiência de cuidado

A Atenção Básica ( $A B)$ pode ser entendida como uma rede institucional, um certo sistema composto de uma rede de serviços que tem em comum certas metodologias e práticas mais ou menos gerais. Contudo, os posicionamentos éticos, clínicos e políticos nesta rede têm, na prática, os mais variados sentidos. Para o problema que aqui tratamos, vemos que as práticas na $A B$, mesmo sendo reunidas sob o mesmo nome e mandato, podem compor com o problema das drogas de formas muito diferentes: ela pode operar (e na prática, na maioria dos casos, assim o faz) de modo a excluir a experiência dos usuários que não se encaixam no padrão preconizado por sua carteira de serviços: aquele que não vive em um domicílio, aquele que não tem família, aquele que usa drogas. Neste sentido o paradigma de abstinência reforça a ideia de que para cuidar dos usuários de drogas e suas questões de saúde é necessário ser especializado no tema.

A complexidade das questões específicas do uso e o abuso de drogas não podem ser tomadas como um problema sem solução, impedindo o contato do trabalhador de saúde com usuário. A complexidade de cada situação clínica precisa ser respondida a partir da multiplicidade dos recursos disponíveis na rede de cuidados. A complexidade da abordagem de um caso de abuso de álcool e outras drogas requer não o isolamento ou um rápido procedimento de encaminhamento a alguma instituição, mas a complexidade de uma rede de atenção. Muitas vezes os trabalhadores não se responsabilizam com os casos de uso de álcool e outras drogas por considerá-los de difícil manejo, deixando a atuação destes casos para os "especialistas" (como se o uso de drogas fosse exceção em seu território!), e deixando 
a responsabilidade do cuidado com este tipo de situação para os serviços especializados em drogas, que na prática, e na maioria das vezes, retiram as pessoas da sua convivência social e familiar. Aí subjaz uma ideia de que a droga só pode ser tratada através da internação, e não como um problema no cotidiano de determinado território, ou seja, in loco.

Contudo, queremos afirmar, por conceito e por conhecimento de causa, que a $A B$ reúne condições para construir um cuidado efetivo com a questão do uso de drogas em seu território. Justamente pelos serviços de $A B$ possuírem o fator essencial para o cuidado: a experiência de e com seu território e população de abrangência. $A A B$, além de uma rede de serviços, tem também um paradigma de cuidado: cuidado longitudinal, baseado nos processos de vida e não na resolução de uma enfermidade, entendendo saúde de forma integral e necessariamente um conceito singular: estar perto da vivência singular e concreta das pessoas, perto do lugar onde se desenvolvem as várias dimensões da experiência, da vida de uma pessoa.

Entendemos que a $A B$ pode servir de contraponto a um modelo de cuidado hospitalocêntrico, apostando em outra espécie de produção de conhecimento: um conhecimento de saúde que se faz em relação de contiguidade, vizinhança e composição com o território de vida concreta de sua população.

Entendemos que a RD, no curso da sua trajetória, promove um olhar cuidadoso para a própria experiência do cuidar. Existe um sentido reflexivo em suas práticas: o cuidado se volta para a própria experiência dos trabalhadores de saúde. Assim, podemos dizer que a RD é uma prática baseada numa ética do cuidado, pois coloca em questão seu próprio movimento, buscando construir-se como uma prática de cuidado em relação ao outro e em relação a si mesmo, lateralizando as posições de cuidador e usuário. 
Em que consiste esta dobra entre experiência e cuidado? A partir dos elementos que analisamos estar presentes na constituição da RD no campo problemático das drogas, vemos um método surgir. Método, ou direções metodológicas, que consistem em criar condições para que se estabeleça o cuidado da experiência:

i- Experimentação: a RD nasce de uma experimentação e constrói seu cuidado pela via da criação de alternativas sintonizadas com as demandas do sujeito e do território: produção de estratégias singulares para cada caso concreto que surge. Nesse sentido, o trabalho da RD está sempre voltado para as modificações das experiências e não para uma meta ideal a ser atingida. As estratégias são maleáveis, negociadas e compartilhadas. A oferta de cuidado não depende da condição de abstinência. Não existe uma meta preestabelecida de qual a relação que o usuário deva ter com a droga: pode ser abstinência total, pode ser mudanças mínimas mas sensíveis. De modo que isso também se aplica à prática do profissional que opera com a estratégia da RD: ele experimenta alternativas, estratégias. Mas essa experimentação não é algo sem parâmetros ou diretrizes, o simples lançar-se a campo. Ela envolve um trabalho sobre o que se experimenta, tanto no caso do usuário quanto do profissional. Para o usuário é importante produzir análises sobre sua história de vida e sobre sua relação com a substância, dar passagem a outras relações com o território, conseguir lidar com as questões que envolvem o prazer e o sofrimento; para o profissional é fundamental construir espaços de análise da experiência: diário de campo, supervisões, produção de narrativas de cuidado calcada no compartilhamento das linhas de cuidado com a equipe, coletivização do vivido na experiência de campo. Trabalhadores e usuários precisam produzir mediações entre a onipotência (do tudo já foi feito) e a impotência (do não há nada a fazer), que afetam tanto a própria da 
experiência de trabalho, como a de uso e abuso de álcool e outras drogas.

É importante produzir linhas de subjetivação, dar nome a estratégias locais e momentâneas. É preciso experimentar formas de analisar a experimentação. Essa dobra da experimentação sobre si mesma permite criar um setting (contexto) de cuidado da experiência. $O$ cuidado da RD não tem meta: o destino se faz caminhando. Mas é preciso caminhar, de modo que a "evolução" tanto do usuário quanto da prática do profissional não pode ser comparada com outra experiência, mas só em relação a si mesma. Um indicador de sucesso poderia ser, nesse caso, não a abstinência total, mas pequenas práticas de abstenção que adotamos cotidianamente na nossa vida social (Nesse momento preferia não usar / Só uso drogas quando não estou trabalhando / Vou dirigir, não posso beber). Desse modo, o trabalhador de saúde tem que estar atento aos pequenos movimentos e às sutis modificações subjetivas operadas durante o trabalho e que permitem novas possibilidades de contato e de abertura comunicacional.

Entendemos que a experimentação permite problematizar e desnaturalizar noções e conceitos operadores que parecem muito certos e definidos, como: a noção de grupo de risco, periculosidade, droga, paciente manipulador e difícil, etc. Assim, além de desmontar ideias prontas que não operam mais ampliação das possibilidades de viver etrabalhar, a RD produz novos conhecimentos, novas narrativas, outros enredos. Mas para esta experimentação e este trabalho sobre a experimentação, a RD deve estar próxima, perto, o que é o segundo sentido metodológico.

ii- Atuação in loco e em processo: A experimentação além de lançar-se na experiência, além de produzir um questionamento ético sobre si mesmo, deve estar atrelada a um território vivo concreto. É preciso habitar, se afetar e 
criar conexões com o ambiente, com o microcosmos com o qual se atua. Sair dos muros das instituições foi fundamental para a construção da RD. Porém não basta sair dos muros, é importante tirar os muros que nos cegam e nos limitam em nossos pensamentos e afetos. Quer dizer, mesmo na rua, estando in loco, é importante guardar a dimensão não instituída de nossas práticas, deixar uma abertura para que o novo surja. De modo que estando in loco, o que se acompanha são paisagens vivas, processos de vida, relações. Isso implica tecer relações de vínculo e cuidado. Para essa construção do vínculo é preciso o terceiro sentido metodológico, que permite também a experimentação.

iii- Conectar segmentos e práticas sociais (instituições, atores, técnicas, éticas, experiências) heterogêneas: experimentar in loco, no território de vida dos usuários, experimentar sua prática, requer uma habilidade de trânsito por diversos segmentos diferentes, com problemas diferentes: a RD se alia com as experiências que ficam à margem, fazendo-as dialogar com os mais variados atores: articula o cuidado às lutas por direitos humanos, aos movimentos sociais ligados às diversas políticas públicas, buscando construir diálogos com diversos setores implicados em seu local de atuação.

Nesses sentidos, a RD tem um pouco de Educação Popular, ao valorizar a construção de saberes locais, e por esse trânsito que opera, por sua proximidade com as experiências daqueles de quem cuida, pela diversidade de atores com as quais estabelece contato, e principalmente, por entender que o problema com drogas não é explicado pela substância, e por outro lado não pode ser entendido como um problema individual. A RD necessariamente vai na direção da integralidade do cuidado em saúde. Esse, entendemos, é sua conexão régia com a Atenção Básica.

Nesse sentido, as práticas na $A B$ ajudam a RD a operar 
nesse sentido da integralidade, ajudando a RD a se fazer presente de modo constante e capilar no território. Mas para isso, a $A B$ também precisa da $R D$, com sua potência de invenção, de mediação com os atores presentes no território, sejam eles quem forem, sem juízo prévio de valor. O papel da mediação é fundamental para ampliar as práticas de cuidado. Ambas precisam uma da outra para caminhar no sentido da integralidade e efetivamente oferecer um cuidado para a questão das drogas de forma ampliada: a droga pode ser o crack, ou o Rivotril, ou mesmo o sal. A substância importa somente na medida que ganha centralidade na vida de uma pessoa, eclipsando todo o resto. $O$ que a $R D$ quer fazer, e o que a $A B$ pode auxiliar em muito, é ampliar as conexões de vida, fazer variar as alianças, os hábitos, fazer com que o processo da vida flua.

No paradigma da RD, na composição com as práticas em $A B$, nunca pode-se cuidar apenas do uso. Assim, a linha de cuidado permite a construção de uma atenção integral: se cuida de DST, tuberculose, de um direito violado, de um direito que precisa emergir como experiência concreta. A RD, entendemos, não deve acontecer em um serviço específico, deve estar infiltrada nos serviços de saúde, e nenhum ambiente melhor na saúde pública para isso do que a Atenção Básica.

A experiência do cuidado exige um cuidado da experiência, que para o trabalhador de saúde é também cuidar de suas práticas profissionais, construindo alianças com as práticas que favoreçam a própria diversidade da vida. 


\section{Referências}

BÓNDIA, J.L. Notas sobre a experiência e o saber de experiência. Revista Brasileira de Educação, n. 19, jan./abr. 2002.

BRASIL. Ministério da Saúde. Secretaria Executiva. Secretaria de Atenção à Saúde. CN-DST/AIDS. A Política do Ministério da Saúde para a Atenção Integral a Usuários de Álcool e Outras Drogas. Brasília: Ministério da Saúde, 2003.

CANGUILHEM, G. O normal e o patológico. Rio de Janeiro: Forense Universitária, 1982.

DIAS, R. Experimentação e cuidado: um campo problemático das drogas e a emergência da Redução de Danos no Brasil. Niterói, 2013. Tese (Doutorado) - Universidade Federal Fluminense, Instituto de Ciências Humanas e Filosofia, Departamento de Psicologia.

MACERATA, I.; DIAS, R.; PASSOS, E. Paradigma da guerra às drogas, políticas de ordem e experiências de cuidado na cidade dos mega-eventos. In: LOPES, L.E, BATISTA, V.M (orgs). Atendendo na guerra: dilemas médicos e jurídicos sobre o "crack". Rio de Janeiro: Revan, 2014.

PASSOS, E.; SOUZA, T. Redução de Danos e saúde pública: construções alternativas à política global de "guerra às drogas". Psicologia \& Sociedade, v. 23, n. 1, p. 154-162, 2011. Disponível em: http://www.scielo.br/pdf/psoc/ v23n1/a17v23n1.pdf. Acesso em: 11 dez 2012.

SALOMÃO, W. Hélio Oiticica: qual é o parangolé? e outros escritos. Rio de Janeiro: Rocco, 2003.

SILVA, A. E. et al. Estratégias de pesquisa no estudo da cognição: o caso das falsas lembranças. Psicologia \& Sociedade, v. 22, n. 1, p. 84-94, 2010. 



\section{Vulnerabilidades do usuário e vulnerabilidades da atenção: apontamentos iniciais para uma clínica de território na Atenção Básica}

lacã Macerata

\section{Introdução}

Partimos do cuidado em saúde com as pessoas em situação de rua para pensar o cuidado com usuários de drogas na saúde pública. Mas o que permitiria a associação? Estaríamos reafirmando o clichê que coloca como sinônimos morador de rua e usuário de drogas? Não se trata disso: nem toda pessoa que vive na rua usa drogas e nem todo usuário abusivo de drogas vive na rua. O uso de drogas permeia todo o tecido social. Malgrado esse simples enunciado, o problema do uso de drogas parece somente se tornar um problema para as políticas públicas quando aparece em um certo tipo de população urbana, de uma certa camada social e que fazem uso de uma certa categoria de drogas: os ditos marginais, aqueles sujeitos que expressam uma experiência fora da ordem (MACERATA; DIAS; PASSOS, 2014), fazendo uso de drogas ilícitas principalmente. Este é um primeiro ponto importante na clínica com usuários de drogas na 
saúde pública: o caráter sempre político das intervenções ${ }^{1}$, na maneira de escolher qual substância é um problema grave, na maneira de eleger qual população é identificada a esse problema, bem como o tipo de tratamento que será empregado. Exemplo concreto: pessoas em condições socioeconômicas miseráveis, vivendo nas ruas grande parte de seu tempo, fazendo uso do crack, para os quais se preconizam internações compulsórias.

Nas políticas públicas, sobre as categorias populacionais "população em situação de rua" e "usuários de drogas" recai a qualificação de populações vulneráveis. Vulnerabilidade seria uma qualificação que denota múltiplas condições, circunstâncias e determinantes que influenciariam negativamente a saúde, a condição social e econômica de determinada pessoa ou grupo populacional. A introdução da noção de vulnerabilidade, como veremos à frente, teria o sentido de buscar desfazer estigmas em relação aos sujeitos - grupo de risco, por exemplo. Pois o estigma também seria outro fator que aproximaria estes dois grupos populacionais: tanto o morador de rua e quanto o usuário de drogas ilícitas sofrem exclusões concretas e contínuas na dinâmica social. Na saúde pública não é diferente: não é incomum equipes de Atenção Básica - e outros serviços de saúde - negarem o acesso às pessoas identificadas a essas categorias. Tomando o caso da Atenção Básica, que é o que nos interessa aqui, é como se ela pudesse atender somente os minimamente "normais", aqueles que não estariam muito distantes dos modos de vida considerados "aceitáveis".

Certamente, na maioria casos, pessoas que vivem nas ruas ou estão abusando do uso de drogas ilícitas estão sob condições que prejudicam em muitos aspectos, e muitas

\footnotetext{
1 Sobre esta questão, ver neste mesmo volume o artigo: "Experiência e cuidado: a experimentação como via de composição entre Redução de Danos e Atenção Básica".
} 
vezes gravemente, sua saúde. Certamente elas exigem um tipo de cuidado que leve em conta essas condições. Porém, esta não é uma exclusividade destas pessoas: alguém que trabalha $18 \mathrm{~h}$ por dia em condições precárias de trabalho, que só se alimenta do lixo oferecido pela indústria alimentar, que trabalha na indústria de agrotóxicos, por exemplo, também está em condição de vulnerabilidade. Contudo, uma pessoa inserida em um grupo populacional que vive em um domicílio, que não faz uso explícito de drogas ilícitas e que não se encontra na camada mais marginal da pirâmide social, geralmente não tem seu acesso barrado e não sofre intervenções compulsórias. Suas condições de saúde não são alarmadas como epidemias, como chagas sociais. Sua vulnerabilidade não se transforma em um estigma. O estigma, o estereótipo construído em torno de pessoas que vivem nas ruas e fazem uso de drogas ilícitas, é concomitante a uma espécie julgamento moral sobre seus modos de viver.

É que estas figuras sociais estariam, de maneira muito incisiva, fora dos padrões aceitos na sociedade ocidental, fora desta ordem social: morando nas ruas, trabalhando de outras maneiras, construindo outras relações comunitárias, estando fora das categoriais de consumidor economicamente ativo, buscando outras relações com a percepção... Além dos problemas que estas práticas em si podem trazer para uma pessoa, as próprias práticas sociais hegemônicas tratam de agravar essas situações: excluindo, e de uma maneira ou de outra, buscando eliminar este tipo de experiência, seja diretamente trancafiando o indivíduo, seja indiretamente buscando remodela-lo segundo os padrões socialmente aceitos.

Como já colocamos, a saúde não foge a estes modos hegemônicos de lidar com esses fora da ordem: ela, muitas vezes, e mesmo se utilizando da categoria de vulnerabilidade, excluí, busca remodelar, eliminar esse tipo 
de experiência da cidade. Ela imputa à vulnerabilidade do indivíduo a impossibilidade de seu acesso, contribuindo para que cada vez mais se diminuam os espaços possíveis para este: "este é morador de rua, é para a assistência social, este é usuário de crack, precisa ser internado", entre outros enunciados que diminuem os espaços de acesso à Atenção Básica e, no limite, à cidade como um todo.

Nossas experiências de intervenções e pesquisas ${ }^{2}$ na saúde, para pessoas que vivem nas ruas e que fazem uso de drogas ilícitas, nos fazem entender a vulnerabilidade neste contexto em dois sentidos: a situação de vulnerabilidade dos usuários atendidos, mas, igualmente, a vulnerabilidade da atenção dos serviços de saúde para cuidar destes usuários. Os vulneráveis evidenciam a vulnerabilidade de nossa capacidade de acolhimento e construção do cuidado para suas condições de vida. Esse é nosso ponto de partida: os usuários de maior vulnerabilidade no SUS evidenciam a própria vulnerabilidade da atenção na saúde pública.

E por vulnerabilidade da atenção não entendemos somente a precarização dos serviços, mas fragilidades técnico-clinico-políticas na maneira de colocar em prática a atenção. Contudo, nossa experiência também diz que é possível construir um cuidado para essas pessoas a partir de elementos já presentes no próprio SUS: a articulação entre as práticas da Atenção Básica, Saúde Mental e Redução de Danos, e sua capacidade de construir o cuidado a partir do território de vida concreto dos usuários.

O surgimento do instrumento que são as equipes de Consultório na Rua $(e C R)^{3}$ é uma evidência desta

2 Nos referimos à experiência de trabalhador em uma equipe de Consultório na Rua (eCR) na cidade do Rio de Janeiro e ao estudo acerca do cuidado ofertado por esta mesma equipe, campo de nossa pesquisa de doutorado em psicologia pela Universidade Federal Fluminense.

3 As eCR são equipes multiprofissionais de Atenção Básica, componentes da Rede de Atenção Psicossocial, criadas em 2012, baseadas no Projeto do Consultório de Rua (de gestão da saúde mental) e em experiências 
possibilidade, já que o mesmo foi idealizado a partir de práticas concretas e exitosas no trabalho com pessoas que vivem nas ruas e usuários de drogas ilícitas. Contudo, como todo instrumento, o sucesso das eCR vai depender da direção e da maneira como elas serão utilizadas: constituirão as eCR um subsistema de saúde, reforçando a exclusão? Terão elas o norte de remodelar as formas de vida dos usuários, segundo os padrões exigidos pela sociedade capitalista, de modo que estes não sejam mais um incômodo à cidade mercado? Ou não, serão as eCR instrumentos de construção outras condições de saúde para seus usuários e de construção de outros potenciais de cuidado no SUS? Neste ponto, embora as direções possam ser confundidas, não há meio termo.

O problema "da direção e do como" que se coloca às eCR se coloca também à Atenção Básica $(A B)$ e ao SUS. De modo que esse é o ponto que queremos chegar neste artigo: apontar diretrizes (direção) e metodologias (como) para o cuidado com vulnerabilidades, tanto das pessoas nas situações de vulnerabilidade, quanto de algumas vulnerabilidades do próprio SUS. Tais diretrizes e metodologias entram no escopo do que viemos chamando de cuidado de territórios de vida, ou clínica de território ${ }^{4}$.

Não se trata de pleitear nenhum tipo de solução para os problemas do SUS, e muito menos para os problemas que pessoas vivendo nas ruas e usando drogas ilícitas colocam à sociedade. $\mathrm{O}$ que temos aqui são apontamentos

de programas de saúde da família sem domicílio.

4 Este é o tema de nossa pesquisa, referida anteriormente: diretrizes, metodologias e dispositivos do cuidado para população em situação de rua. Tal pesquisa, ainda em andamento, constituiu-se de grupos de discussão com trabalhadores da eCR do Centro da cidade do Rio de Janeiro, que buscava enunciar a direção e a metodologia de trabalho praticadas por eles no cuidado em atenção básica com a população em situação de rua. Os grupos aconteceram de março de 2013 a abril de 2014, e tiveram como produto um documento técnico de autoria dos pesquisadores e trabalhadores. 
iniciais para o cuidado com essas populações, advindos de uma pesquisa realizada junto a uma eCR, e também de nossa experiência nas políticas públicas para pessoas em situação de rua ${ }^{5}$. Apontamentos que sustentamos serem profícuos tanto ao atendimento de pessoas que vivem nas ruas quanto de pessoas que fazem abuso de drogas ilícitas e outras drogas.

Façamos nosso pequeno percurso, passando pelo que estamos entendendo por vulnerabilidades, pelos potenciais de construção do cuidado a elas no SUS e chegando às direções e metodologias iniciais de um cuidado dos territórios de vida.

\section{Vulnerabilidades}

Ao discutir o marco conceitual da noção de vulnerabilidade, Monteiro (2011) fala que ela foi trazida do campo jurídico para o campo da saúde, principalmente pela questão do HIV. A utilização do termo buscava superar a noção de risco social ou grupo de risco, com o sentido de ampliar a compreensão da suscetibilidade aos agravos de saúde, deslocando o foco do individual para considerar os aspectos do contexto social. A noção de vulnerabilidade identifica indivíduos, grupos e comunidades que estão expostos a condições de maiores níveis de risco nos planos sociais, políticos e econômicos, condições estas que afetam a vida individual, familiar e comunitária. Uma situação de vulnerabilidade diz respeito aos múltiplos condicionantes, não sendo algo inerente a uma pessoa ou grupo, mas à determinadas condições e circunstâncias que poderiam

5 Experiência que passa pelas políticas de assistência social e saúde, pelos lugares de trabalhador e pesquisador dessas políticas. 
ser revertidas. Por isso, tal noção tem sua importância nas políticas públicas: a diminuição dos níveis de vulnerabilidade social pode se dar a partir do fortalecimento dos sujeitos através do acesso à bens, serviços e direitos que as políticas públicas têm a função de ofertar.

Entendemos que há um ganho quando a discursividade da saúde pública abandona o conceito de "risco" e "população de risco", assumindo a ideia de vulnerabilidade, já que busca deslocar a ideia de que uma condição vivida por um sujeito é algo inerente a ele, ou algo unicamente de sua responsabilidade. Mas a própria noção de vulnerabilidade pode denotar unicamente um adjetivo atribuído a um sujeito, o que isola a vulnerabilidade como algo que não implica, ou implica muito pouco o restante das práticas sociais.

Vamos entender que é preciso ir além: além de considerar as condições vividas por uma pessoa, os processos de produção dessas condições, é preciso implicar as intervenções sociais que agem sobre essas pessoas. É preciso avançar nesta modulação de sentidos. Propomos tomar as populações vulneráveis como analisadores ${ }^{6}$ das vulnerabilidades dos modelos de atenção do SUS. Na saúde, é fundamental deslocar a vulnerabilidade do sujeito para as condições sociais. Mas parar aí, ainda é constituir um objeto de intervenção no qual nós, os interventores, não estamos implicados. Geralmente falamos que tal grupo ou indivíduo tem características ou está inserido em um contexto que dificulta o tratamento, mas não pensamos nossas dificuldades em tratar. Não avançamos muito quando substituímos população de risco (como os antigos grupos visados pelas ações sanitárias da DST/ AIDS) por populações vulneráveis, pois ainda estamos

6 Um analisador é um ponto crítico que permite a análise de configurações de linhas institucionais e de linhas de força em determinada localização espaço/temporal. (BARROS, 2007) 
excessivamente localizacionistas. É preciso deslocalizar o problema sanitário, entendendo que sua natureza última é o território de vida do usuário. E este território de vida é feito e composto também pelas redes de cuidado que nele presente.

\section{Atenção Básica: vulnerabilidades e potencialidades}

A noção de vulnerabilidade, na maneira como geralmente é utilizada, nos traz o risco de construirmos um objeto de intervenção e de nos relacionarmos com ele de maneira distanciada: tiramos o foco do indivíduo, para considerarmos seu contexto, mas não questionamos 0 quanto nós, enquanto agentes da saúde pública, produzimos este contexto em nossas práticas. O que podemos observar na prática de muitas equipes de Atenção Básica $(A B)$ são algumas dificuldades concretas que ficam muito evidentes no trato com esses modos de vida fora da ordem.

Algumas dificuldades da atenção se mostram decisivas no fracasso do cuidado. Dificuldades em: (i) construir um entendimento e uma ação que considere várias dimensões da saúde (físico/biológica, mental/afetiva, social/econômica); (ii) conceber e agir no território, para além da matriz domiciliar, quer dizer, entender o contexto de vida da pessoa para além de sua casa e de sua família; (iii) construir as ofertas de saúde a partir das necessidades do território e não da carteira de serviços padronizada na Atenção Básica; (iv) construir diálogos e ações conjuntas com outras políticas públicas (intersetorialidade). $\mathrm{O}$ que esses fatores têm em comum é que eles são fundamentais para darmos direção ao princípio da integralidade em saúde. 
Um exemplo muito concreto disso são os pacientes que sofrem de algum transtorno mental ou que fazem uso abusivo de álcool ou outras drogas e, ao mesmo tempo, apresentam alguma morbidade biológica clara. Estes pacientes caem no que pode se chamar o buraco da rede: eles não são atendidos na $A B$ porque estão em sofrimento psíquico; não são atendidos na saúde mental porque estão com alguma doença que não se pode tratar ali. Quando um sujeito reúne estes dois tipos de demandas e ainda é morador de rua, a situação fica ainda mais complicada: "o paciente não tem domicílio, então não é de minha área de abrangência". Pois os usuários mais vulneráveis vão apresentar esta gama muito imbricada de demandas de saúde, e ainda outras demandas para outras políticas públicas, mas que se fazem presente e influenciam as condições de saúde: violação de direitos humanos, exclusão de acesso a moradia, trabalho e renda, educação, convivência comunitária. Em contrapartida, a maioria dos serviços de saúde têm sérias dificuldades em conceber e lidar com esta complexidade. Não queremos com isso "culpabilizar" as equipes, os profissionais: essas dificuldades remetem ao SUS como um todo, aos saberes e práticas que o constitui e à sociedade em geral.

Sobretudo, queremos afirmar que considerar vulnerabilidades não significa reduzir as vidas nelas inseridas a essas condições: um usuário de drogas é sempre mais que um usuário de drogas; uma pessoa que vive na rua é muito mais que alguém sem domicílio. Eles são outros modos de vida, com suas vulnerabilidades específicas e com suas outras potencialidades. Assim também pensamos as práticas possíveis em Atenção Básica.

Se avaliarmos a lógica de cuidado proposta pela Atenção Básica, podemos perceber seu alto potencial de ir em direção a uma concepção e uma prática de 
cuidado integral, justo por sua capacidade de conexão com outros saberes e práticas e por sua direção de estar em contiguidade ao território. E este para nós é um ponto decisivo: a possibilidade de misturar $A B$, práticas em Redução de Danos e em Saúde Mental, pela capacidade que estas têm em considerar e atuar através dos territórios de vida.

A AB tem como lógica do cuidado a construção de suas estratégias a partir dos territórios: se fazendo presente nele, acompanhando seus processos, se fazendo acessível, escutando suas demandas e características. (CUNHA, 2004) A Saúde Mental pós reforma psiquiátrica também passou a exercer seu trabalho no território cotidiano da cidade, deslocalizando e descentralizando o local de atenção, realizando uma desinstitucionalização, que é uma deslocalização e abertura dos espaços do cuidado. (FURTADO; PASSOS, 2012) Já a Redução de Danos é a prática precursora de uma atuação junto ao território de vida dos usuários, e sobretudo, uma prática que se utiliza dos elementos presentes nestes territórios para construir suas estratégias: quer dizer, utiliza as condições que em um primeiro momento só aparecem como de risco, para revertêlas em um cuidado com linguagem e método acessível a seus usuários, fortalecendo elementos potenciais presentes em seu próprio cotidiano. Assim nascem estratégias de cuidado que advém da mais radical aproximação junto ao território de vida na maneira como ele se apresenta. Deste modo, se fazendo menos como redução de riscos, e mais como ampliação de vida, das possibilidades de uma vida concreta. (LANCETTI, 2008)

Podemos entender que essas três lógicas apontam para uma direção comum do cuidado: atuar junto ao território onde o usuário vive, e não retirá-lo de seu território. Entende-se território sempre como território 
vivo, território de vida: mais que uma demarcação espacial, mas um plano onde se constitui e se desenrola uma vida, as relações que produzem uma vida, onde estão em jogo todas as dimensões da vida de um sujeito. Território de vida é um meio relacional. Uma pessoa não é algo fechado em si, mas só se constitui em suas relações, como um nó do tecido de realidade, uma conjunção singular, particularidade específica fundamentada em um território de relações.

\section{Apontamentos metodológicos para uma clínica de território}

Não é à toa que a proposta das eCR é baseada nesta articulação $A B, S M$ e RD se dando in loco. Nesta conjunção do que poderíamos chamar de paradigmas do cuidado na $A B, S M$ e $R D$, e principalmente a partir das experiências de pesquisa e intervenção já citadas, temos diretrizes e metodologias que ajudam a definir o que seria um cuidado dos territórios de vida?

Em primeiro lugar o termo cuidado não se restringe à atuação de um agente cuidador: ele é uma relação de cuidado, uma articulação entre sujeitos (profissionais, usuários e outros atores) e territórios. Cuidado então é sempre uma relação de cuidado. Neste sentido, o cuidado com o usuário e o território é inseparável do cuidado com as redes de saúde, com a cidade. E ainda, inseparável do cuidado do trabalhador, da equipe e de seu processo de trabalho.

7 Cabe ressaltar que estes trechos são apontamentos iniciais, porque a pesquisa realizada para sua construção ainda está em andamento; além disso, por clínica de território não deve-se entender nenhuma especialidade clínica, mas diretrizes e metodologias para a construção do cuidado: um modo de pensá-lo e articular conhecimentos. 
A partir desta definição inicial mas fundamental, temos algumas diretrizes para este cuidado assim se constituir. São elas: (i) diretriz de acompanhamento longitudinal: acompanhar o paciente ao longo do tempo e do território onde ele habita, onde a longitudinalidade do cuidado não significa uma forma preestabelecida de periodicidade, encontro diário ou semanal. Acompanhar longitudinalmente significa acompanhar o paciente pelos lugares onde ele passa: seja na rua, seja em atendimento em alguma instituição, seja em internação; (ii) diretriz de Acolhimento: acolher o usuário nas suas condições de vida concretas, não tendo nenhum tipo de exigência preestabelecida para seu atendimento. $O$ acolhimento consiste em uma postura presente em todas as ações da equipe; (iii) diretriz de inclusão do usuário nos espaços institucionais da rede de saúde e da cidade: incluir o usuário nos espaços do SUS e da cidade é trabalhar para que a rede de saúde e a cidade possam conviver e respeitar os usuários em suas condições de vida, trabalhando as redes para que seja garantido seu acesso, garantido a adaptação dos fluxos da rede às necessidades do usuário; (iv) diretriz de Articulação intersetorial: a busca por um olhar integral é inseparável da articulação com outras políticas públicas; (v) diretriz do Cuidado do território, no território e para o território: a relação com o território da rua é o primeiro recurso do serviço para construir seu cuidado. Esta relação se faz por uma ocupação e presença da equipe de saúde no território que cuida. Cuida-se do território como um todo, não se responsabilizando por tudo, mas se engajando na melhoria das relações dentro de um território. E ainda, se cuida para atender as demandas do território, e não para atender demandas externas a ele, demandas que não estão preocupadas com o bem estar das pessoas deste território. De modo que o cuidado é construído a partir do território, e não de fórmulas prontas que não dialogam e consideram 
sua realidade específica; (vi) diretriz do olhar integral $e$ clínica ampliada: o foco do cuidado é nos processos de vida do usuário, e não em enfermidades. Neste sentido o profissional acolhe as demandas de saúde expressa em doenças e queixas, mas busca inseri-las em um contexto maior: a vida em um território. É preciso que o profissional escute as questões, a história de vida, a relação com a rua do paciente para além do adoecimento.

Se temos direções, é preciso indicar como se fazem tais direções, o "como fazer". São os apontamentos metodológicos: (i) escuta ampliada: acolher as queixas imediatas buscando transformá-las em demandas de cuidado, o acolhimento e o manejo com as queixas se fazendo a partir de uma ampliação da escuta, propiciando a construção de demandas, que é algo maior do que a cura de uma enfermidade pontual. É preciso construir um plano terapêutico que envolva vários profissionais diferentes, e até outros serviços. Para poder ampliar a queixa e transformála em demanda, é preciso um olhar e uma escuta ampliada, um olhar que saia da especialidade e vá em direção a integralidade, um olhar generalista;(ii) Construção $e$ promoção de espaços de atendimento diversos: construir espaços de atendimento diversos, é poder atender na sede do serviço, mas também na rua e em outras instituições, trabalhando para que estes espaços possam se constituir como locais efetivos de cuidado;(iii) Construção de vínculo: o vínculo se estabelece quando a equipe ou um profissional serve de referência de cuidado para o paciente. O vínculo é um dos componentes que sustenta o processo do cuidado. A construção do vínculo é um processo gradativo. O vínculo é construído não só na relação direta com o paciente, mas também com o território que o envolve. Assim, ele é feito através de presença no território, uma presença que oferece primeiramente "cara e ouvido", quer dizer escuta, presença contínua e atenção; (iv) Promoção de autonomia: a relação 
de cuidado envolve necessariamente a promoção da autonomia do paciente. A autonomia é promovida quando a equipe trabalha com o paciente estratégias de autocuidado, e trabalha com seu território a possibilidade do paciente se cuidar melhor em seu território. A equipe promove autonomia quando intervém junto aos atores no território do paciente. Autonomia não é o ideal de um indivíduo totalmente independente, mas sim na possibilidade deste aumentar seus laços relacionais com pessoas, instituições e práticas diversas. Nesse sentido autonomia é sempre coletiva, sempre se mede pela capacidade do indivíduo estabelecer relações. Se o cuidado tem como norte a autonomia, o paciente pode escolher não se tratar; $(v)$ Tensionar as redes: é preciso tensionar as redes de saúde e outras políticas de direito para que os usuários possam ter suas necessidades atendidas. Tensionar tem tanto o sentido de intensão de criar redes, quanto de criar tensão, crise que permite o envolvimento efetivo da rede no cuidado do usuário. Montar um projeto terapêutico adequado ao caso, geralmente, tem o efeito de criar um espaço de cuidado para o usuário na rede, assim como acompanhando o usuário por entre os pontos da rede, construindo fluxos de referência e contra referência;(vi) Conexão entre lógicas heterogêneas: para incluir os usuários e ampliar a clínica é necessário articular diferentes perspectivas e funcionamentos, criar conexão entre os diversos atores que compõe o território de vida do usuário: a família, sua comunidade, os atores de políticas públicas; (vii) Mapear constantemente o território: o conhecimento do território ajuda a legitimar e acolher as queixas e, consequentemente, é o primeiro passo para a construção da demanda e para o desenho do cuidado. A construção deste conhecimento se dá por habitar o território e construir um entendimento com ele. Este mapeamento pode ser expresso em desenhos do território e também em conversas e avaliações sobre 
sua situação, identificando atores, riscos potencialidades. Este nunca é um entendimento definitivo, mas está sempre em construção;(viii) Ocupar e pautar os espaços políticos: a equipe de $A B$ não vai garantir todos os direitos ao seu paciente, mas vai promover acesso a políticas públicas, pautando os espaços institucionais da cidade no que diz respeito às necessidades encontradas em seu território.

\section{Conclusão}

As direções e apontamentos metodológicos acima mencionados não se constituem em nenhuma fórmula e muito menos fazem todo o caminho necessário para a resolução das vulnerabilidades da atenção. São em verdade apontamentos básicos e já presente em muitas práticas. Contudo, apostamos que é este básico da atenção que é preciso garantir, pois são noções básicas que consideram as múltiplas vulnerabilidades envolvidas em uma relação de cuidado, que consideram o enorme desafio que é constituir políticas de cuidado no contexto da saúde pública brasileira. E é com este básico que pensamos ser possível encontrar alternativas de superação de vulnerabilidades, ao menos do que diz respeito a competência e possibilidade de equipes de Atenção Básica. 


\section{Referências}

BARROS, R. B. Grupo: a afirmação de um simulacro. Porto Alegre: Sulina/Editora da UFRGS, 2007.

CUNHA, G. T. A construção da clínica ampliada na Atenção Básica. Campinas: 2004. Dissertação (Mestrado) Universidade Estadual de Campinas. Faculdade de Ciências Médicas, 2004.

FURTADO, R.; PASSOS, E. Espaço e loucura: uma análise dos espaços de cuidado na reforma psiquiátrica. In: SAÚDE mental coletiva. Clínicas e vulnerabilidades. 1. ed. São Paulo: Schoba, 2012. p. 409-430.

LANCETTI, A. Clínica Peripatética. São Paulo: Hucitec, 2008.

MACERATA, I.; DIAS, R.; PASSOS, E. Paradigma da guerra às drogas, políticas de ordem e experiências de cuidado na cidade dos mega-eventos. In: LOPES, Lucília Elias; BATISTA, Vera Mallaguti. Atendendo na guerra: dilemas médicos e jurídicos sobre o "crack". Rio de Janeiro: Revan, 2014.

MONTEIRO, S. O marco conceitual da vulnerabilidade social, 30. Sociedade em Debate, Pelotas, v. 17, n. 2, p. 29-40, jul./ dez. 2011. 


\section{Parte III}

\section{Relatos, narrativas e experiências}





\title{
Acompanhando Manu: álcool e drogas nos (des)encontros da rede de cuidados ${ }^{1}$
}

\author{
Aisllan Diego de Assis
}

\section{Introdução}

Durante a residência em psiquiatria e saúde mental ${ }^{2}$ tive a oportunidade de cuidar de pessoas com transtorno mental. Sujeitos e famílias que num exercício existencial incrível e exaustivo, levam suas vidas convivendo com o sofrimento psíquico. Sofrimento advindo da estranheza da doença fantasma, do estigma trazido pelo transtorno mental, da dureza de uma vida regrada e dos inúmeros enfrentamentos postos na busca por cuidado e solução de suas mazelas. Eu as encontrava nas unidades de saúde onde atuava como aprendiz e juntos travávamos projetos, lutas e pequenas conquistas. Como principal elemento de junção entre nós havia minha disponibilidade de ajudá-los com os conhecimentos que detinha, mínimos às vezes ante tantas necessidades, assim como a oportunidade de ajuda e acolhimento que elas viam nesses encontros. Buscávamos uma relação de cuidado.

1 Texto escrito com base na dissertação de mestrado "Viver livremente": trajetos e passagens de uma fuga do cuidado. Apresentada e aprovada no Instituto de Medicina Social da UERJ. Rio de Janeiro, 2014.

2 Especialização na modalidade de Residência em Enfermagem de Psiquiatria e Saúde Mental pelo Hospital Universitário Pedro Ernesto (HUPE) da Universidade do Estado do Rio de Janeiro (UERJ), 2010-2012. 
Nem sempre era possível realizar o projeto como construíamos nas diversas reuniões, supervisões e encontros com os pacientes e seus familiares. As dificuldades eram grandes: laços familiares esgarçados, adoecimentos graves, rede de amizades e filiados incapaz de responsabilizarse pelo cuidado e, claro, as constantes barreiras sociais e culturais erguidas na sociedade no que se refere à loucura e ao transtorno mental.

Foram muitas às vezes em que a comunicação, as ações de cuidado e a tomada de decisão eram tensas e carregadas de desentendimentos que se mostravam mais separadoras que integrais. No meio destes embaraços estava um ser inteiro: subjetividade, corpo e história numa experiência de adoecimento buscando cuidado e ajuda. O projeto terapêutico era uma produção possível que as equipes propunham para cuidar "por inteiro" destas pessoas e em algumas vezes se materializava em ações isoladas e desarticuladas realizadas pelos profissionais, sem muita comunicação não só entre si, mas também com o paciente e a família.

Eu atuei como profissional de referência ${ }^{3}$ durante minha passagem na internação, no ambulatório e em outros serviços. Esse acompanhamento de pacientes se desdobrou em uma rica experiência de aprendizado, de modo que nessa relação vivenciei um dos desafios do trabalho em saúde mental: cuidar de pessoas com transtorno mental em situação de comorbidade clínica.

Dois destes casos exigiram de mim um esforço grande no que se refere aos estudos e atuação política. Fui

3 O Profissional de referência tinha como responsabilidade monitorar junto com o usuário o seu projeto terapêutico. O profissional de referência também era responsável pelo contato com a família e pela avaliação periódica das metas traçadas no projeto terapêutico, dialogando com o usuário, família e outros profissionais da equipe. 
profissional de referência de Maria e Carlos ${ }^{4}$. Conheci ambos quando ficaram internados na enfermaria de psiquiatria. Juntos fomos companheiros na busca por cuidado, a eles principalmente, bem como na garantia de seu direito a saúde.

Os dois pacientes e suas histórias como companheiros em minha evolução como enfermeiro colocaram-me ante a dificuldade de cuidar de pessoas que além do transtorno mental carregam em seu corpo outros agravos. Maria com uma fratura e Carlos com um vírus eram improváveis pacientes para um sistema de saúde organizado em especialidades e "pacotes terapêuticos" onde o que importa são sinais e sintomas de um corpo, ou mente, reduzidos à descrição de cada especialidade do trabalho em saúde. Eles são os que travavam o sistema, os "pacientes bomba", os "complexos" para o mundo dos cuidados fragmentados e ultra especializado.

Acompanhá-los e cuidá-los me pôs algumas vezes frente a frente com colegas profissionais que não queriam atendê-los, que achavam que não eram pacientes para aquele serviço específico, que precisavam sempre estar acompanhados ou amarrados por serem violentos, que precisavam ter ao seu lado "pessoas da psiquiatria" para serem atendidos, prejudicando suas vidas negando-lhes o cuidado integral por direito garantido.

Com a eminência da alta hospitalar continuei acompanhando Maria e Carlos. Ela em suas idas e vindas ao ambulatório e ao fisioterapeuta. Ele nas consultas de psiquiatria e de infectologia. Nossos desafios não foram muito diferentes quando o fluxo que seguíamos era fora do hospital. A cidade e sua rede de serviços se mostravam mais desintegradores no atendimento a eles.

4 Nomes fictícios, como todos os demais utilizados no texto, no sentido de proteger suas identidades. 
O centro de reabilitação não queria atender Maria. Carlos tinha dificuldades em cuidar das infecções oportunistas ${ }^{5}$, principalmente quando necessitava de internação em unidade de clínica médica ou de doenças infectocontagiosas. Com eles percorri algumas vezes caminhos que ofereciam mais problemas que soluções. Por fim, concentrar todos os atendimentos no hospital que estávamos vinculados foi a última escolha para não transitar mais na cidade e nos serviços de saúde que se fechavam a eles. Os caminhos todos foram reduzidos ao percurso de suas casas ao hospital, o que ainda não significou um encontro com o cuidado integral que necessitavam.

Esses dois casos me exigiram investir em estudos que me orientassem a entender como a produção social das doenças constituem-se como verdadeiros desintegradores da condição individual de cada pessoa. Ser portador de transtorno mental e ter outras doenças é um complicador na busca por cuidado em saúde no sistema que se propõe único, universal e integral. Essas pessoas não eram moradores de manicômios, eles residiam na cidade, transitavam por ela em busca de cuidado para outras coisas que não eram seus estranhos comportamentos e, na maioria das vezes, eram forçados a retornar aos lugares construídos neste sistema para aprisioná-los como eternos pacientes.

Desta forma, no contexto dessa experiência ao mesmo tempo profissional e de formação, elegi como objetivo de meu estudo de mestrado em saúde coletiva compreender a busca por cuidado de uma pessoa com transtorno mental em de situação comorbidade. Segundo a Organização Mundial de Saúde (PAES; MAFTUM;

5 Infecções oportunistas são doenças que se aproveitam da fraqueza do sistema imunológico, que cuida da defesa do organismo. Como os principais alvos do HIV, vírus causador da AIDS, são essas células de defesa, compõe a síndrome recorrentes infecções que às vezes precisam ser tratadas por internação hospitalar. (Brasil. DST/AIDS. Portal da Internet. Acessado em 02/03/2013) 
MANTOVANI, 2010), comorbidade consiste na presença de doenças coexistentes ou adicionais com relação ao diagnóstico inicial ou com relação à doença principal. Em psiquiatria, o termo comorbidade clínica é utilizado para referir-se a doenças ou diagnósticos - além de problemas mais genéricos - presentes em portadores de transtorno mental, constituindo situações psicossociais complexas. (GOMES, 2012)

A pessoa com transtorno mental em situação de comorbidade que segui e acompanhei durante a pesquisa era considerada pelos profissionais do hospital psiquiátrico no qual a encontrei 'alcoolista' - e sua comorbidade psiquiátrica - e também 'hanseniana' - sua comorbidade clínica. Vou chamá-la de Manu e contar a seguir os (des) encontros entre ela e a rede de cuidados carioca devido principalmente "seu maior problema".

\section{O campo}

Conhecia o lugar que elegi para iniciar a pesquisa, pois alguns dos usuários do SUS que atendi foram para lá referenciados em alguns momentos. O hospital psiquiátrico dispõe de emergência e enfermaria, bem como ambulatório e hospital-dia. Trata-se de uma referência estadual para o atendimento a portadores de transtorno mental.

Para realizar a pesquisa solicitei e obtive autorização tanto da direção do hospital psiquiátrico quanto de um Comitê de Ética em Pesquisa. Com a autorização passei a frequentar o hospital, convivendo semanalmente com os profissionais e pacientes. Acompanhei os profissionais em atendimentos, reuniões e eventos que ocorreram no período que frequentei o hospital. Convivi com os pacientes 
em diferentes espaços do hospital: foram momentos de conversas, jogos e brincadeiras no hospital-dia, refeições e atividades musicais. Foi lá que conheci Manu. E de lá parti acompanhando ela e seus familiares, construindo um itinerário terapêutico que visualizava o modo pelo qual todos eles seguiram buscando cuidado para seus problemas.

Como esse percurso e itinerário se deu nos territórios da cidade, acompanhei Manu em seu deslocamento seguindo suas buscas pelos serviços de saúde e/ou lugares não formais de cuidado (igrejas). Registrei conversas em meu diário, do mesmo modo como pura e simplesmente conversei com usuários, familiares e profissionais ao longo dos caminhos. Essas conversas eram a maneira que tinha para esclarecer situações ou informações recolhidas nas observações e documentos. A pesquisa foi realizada de julho a dezembro de 2013. Assim, o itinerário terapêutico de Manu foi construído ao longo de seis meses de acompanhamento dela dentro e fora de hospitais, casas, policlínicas e unidades básicas de saúde, pelas ruas da cidade inclusive.

Os itinerários terapêuticos são desenhos que possibilitam conhecer e reconhecer na trajetória de vida das pessoas percursos feitos em situação ou momentos de adoecimento. Possibilitama expressãode uma multiplicidade heterogênea de movimentos, agenciamentos e concepções acerca da saúde, da doença, da vida e da morte. (GERHARDT, 2006) Bonet (2012) usa o termo "Itinerários de Cuidados Terapêuticos" quando se refere aos movimentos que as pessoas fazem pelo sistema de saúde em seus processos de saúde-doença. Nesses processos de deslocamentos pelo sistema de saúde os usuários vão estruturando o sistema de saúde, que frequentemente não coincide com a estrutura que os gestores do sistema de saúde pensaram para ele. Ao se movimentar pelo sistema de saúde os usuários tomam decisões e, com elas, vão construindo uma história. 
Viver e narrar (DALMOLIM, 2006), seguir e acompanhar (INGOLD, 2012) foram modos de buscar compreender o itinerário terapêutico de Manu, contar um pouco de sua história e aprender com os encontros e desencontros que aconteceram em suas passagens pela rede de cuidados.

Nesse texto pretendo contar um pouco dessa história que eu e Manu vivemos juntos. Darei destaque a um momento que compartilhamos: um que chamo de (des) encontro do cuidado.

\section{Conhecendo Manu}

O primeiro encontro com essa mulher aconteceu cinco dias após sua chegada num hospital psiquiátrico. Ela vivia nas ruas do centro da cidade e fora recolhida nas ações que a prefeitura da cidade realizava para retirar pessoas das ruas. Sua situação de saúde e mais particularmente a história de sua vida foram formando um quadro de difícil compreensão, pois não era possível afirmar que ela tinha transtorno mental segundo os profissionais que a avaliaram incialmente, mas era evidente o quanto seu corpo estava adoecido. Magra, febril, com uma fala confusa levaram os médicos que a atenderam a concluir que ela precisava de ajuda, e rápido. Eles teriam que lidar ainda com um problema que agravava toda a saúde da mulher. Ela chegou ao hospital ainda com cheiro de bebida alcoólica e contou aos profissionais que a atenderam na emergência que bebia há muitos anos. Foi o primeiro aparecimento de sua pessoa: uma mulher, moradora de rua, embriagada e a beira de um colapso de sua saúde. Os profissionais que a atenderam nessa chegada disseram que foi sorte ela ter sobrevivido.

Ela chegou ao hospital psiquiátrico e foi atendida na 
emergência psiquiátrica. O médico que a avaliou afirmou que ela não tinha nenhuma doença psiquiátrica que justificasse sua internação. Segundo a avaliação do médico ela estava em Delirium devido ao uso abusivo do álcool. Não era um caso psiquiátrico, era um caso clínico. Assim, ela foi levada a uma emergência de um hospital geral no centro da cidade para ser avaliada e medicada. Passadas algumas horas a mulher retornou na ambulância do hospital psiquiátrico. Depois de uma longa espera os médicos do hospital geral avaliou que a mulher tinha "bom estado geral". Nenhum exame havia sido realizado e segundo a enfermeira do hospital psiquiátrico que a acompanhou "os médicos nem encostaram nela para examinar".

De volta ao hospital psiquiátrico por uma determinação da direção do hospital Manu foi internada. Não era possível que ela fosse atendida em outro lugar e mesmo sendo considerada um caso clínico ela foi levada para a internação psiquiátrica e foi ali, no pátio onde os pacientes tomam sol que conversamos pela primeira vez com. Junto com a psiquiatra supervisora ouvi pela primeira vez um pouco de suas histórias.

Depois de algum tempo de conversa a psiquiatra concluíra que essa mulher precisaria de muita ajuda. Ao rever os resultados dos primeiros exames feitos e retomar a conversa que teve com ela os médicos sugeriram que a mulher seja uma alcoolista. Mas ainda não era possível afirmar que ela sofria de algum transtorno psiquiátrico. A única certeza é que era uma pessoa que demandaria muitos cuidados.

Esquizofrenia, demência e alcoolismo foram os diagnósticos que Ihe foram atribuídos pelos psiquiatras. Acrescido do diagnóstico de Hanseníase, como comorbidade clínica, que nas palavras da irmã e do cunhado dava-lhe o atributo de "leprosa". 


\section{O (des)encontro do cuidado}

Busquei entender como os profissionais realizavam o cuidado a Manu, atentei-me às suas práticas, e quando falavam, buscava compreender como articulavam o conhecimento que tinham às decisões que tomavam. Acompanhei - os em reuniões, atendimentos aos pacientes e familiares e lia seus registros. Minha tentativa era compreender a lógica que punham em funcionamento no conjunto de ações e decisões que tomavam diariamente. Dessa observação emergiu duas categorias de destaque: as drogas e a família.

As drogas e o álcool eram reincidências nos casos: Manu era alcoolista, um paciente jovem que estava internado dizia não querer parar de fumar maconha, outro paciente era internado constantemente devido ao uso de cocaína, "depois que o crack chegou tudo ficou mais difícil" disse-me uma técnica de enfermagem.

A família era um personagem que compunha o caso, às vezes ela tornava-se o objetivo central dos cuidados. Uma filha que não conseguia morar com a mãe, uma irmã que não suportava mais os comportamentos estranhos e agressivos de seu irmão, a família que "abandonou" Manu no hospital e as "mães esquizofrenizantes" são todos modos de apresentações da trama parental. Os profissionais do hospital psiquiátrico lidam com drogas e famílias cuidando de pessoas que por ali passam internadas, nos espaços abertos e na esquina do prédio.

Ser usuário de drogas ou "dependente químico" era algo que fugia do perfil dos casos que poderiam ser atendidos em quase todos os espaços do hospital. Porém, foram-me relatos casos de pessoas que fugindo ao perfil, eram cuidadas pelas equipes. Contudo, esses casos eram sempre notados pelos profissionais como os casos que 
figuravam a separação que cunhavam entre "psicóticos" e "dependentes químicos".

Eram pessoas que juntavam numa só performance mais uma separação, dessa vez dentro da especialidade médica. Ser "louco", "bêbado" ou "drogado" era desafiar a separação que qualificava o perfil de pessoas a serem cuidadas no hospital. Esse aparecimento punha no mesmo horizonte Manu, que apesar de não se saber ainda se era "psicótica" já a tinham como "alcoolista", dois outros pacientes que conheci na internação psiquiátrica, e uma das mulheres que vivem na esquina do hospital. Essa mulher é paciente do ambulatório e esteve também internada durante o tempo que estive realizando a pesquisa. Eles combinavam o que perfil separava: loucura e drogas.

Nessa conjugação percebi que as drogas e o álcool eram mediadores dos elementos que se separavam na aplicação dos saberes biomédicos e da psicanálise. Eles borravam as fronteiras de separação ou juntavam as dicotomias criadas para explicar e analisar os casos. Assim, a história de uma pessoa, seus adoecimentos ou sua psicose eram atravessados pelo aparecimento das drogas ou do álcool como componente do caso. Esse aparecimento aumentava a tensão estruturante das dicotomias operadas nas práticas. $O$ cuidado que era ofertado a essas pessoas era uma produção possível nesse conjunto sempre tenso e desafiador marcado pela constante separação e junção de elementos componentes de um caso.

O "vício de bebida forte" e a vontade de beber "bebida que embriaga" eram registrados quase que em todos os relatos de Manu. Parecia que em todas as conversas registradas pelos os profissionais, o álcool aparecia e era anotado por eles. O registro mais contundente gravou no prontuário que Manu havia dito que o "vício de bebida forte" era "seu maior problema". Desde sua entrada na emergência 
do hospital até o momento de sua saída o alcoolismo foi recorrente nas histórias de Manu, como moradora das ruas, como emergência médica e como interna do hospital psiquiátrico. Esse elemento foi registrado nos diversos documentos que relataram esses trajetos e passagens: "odor etílico", "etilismo crônico", "vício de bebida forte".

Como contei acima Manu afirmava que tinha "vício de bebida forte", dizia que tinha no álcool "alivio" paras as tristezas ao mesmo tempo o "vício era seu maior problema". Vício e alivio eram maneiras de Manu traduzir o quanto se comprometera tornando - se uma alcoolista. E era exatamente "seu maior problema" que causava os grandes desencontros na rede de cuidados.

Em todas as passagens de Manu por serviços de saúde "seu maior problema" o "vicio de bebida forte" foi expresso inúmeras vezes. Confessando a vontade quase incontrolável que tinha de beber "bebida que embriaga" ela dizia "sofrer de maus tratos". A única ação de saúde que focou em "seu maior problema" foi a elaboração de um "encaminhamento" a um serviço especializado para o tratamento de dependência química. Esse serviço nunca foi buscado pela família e por seguinte também por Manu. A família afirmava que ela precisava ser "libertada", assim o alcoolismo não era considerado uma doença, mas uma "possessão demoníaca" que teria seu fim com a "conversão".

Os profissionais de saúde por sua vez focavam no tratamento da hanseníase, no processo reabilitador das mãos e braços e já nos últimos trajetos de seu itinerário terapêutico buscaram um serviço especializado para ajudála, o núcleo de atenção à saúde da família (NASF). Mesmo assim, à vista estavam os conflitos familiares e o possível afastamento com seu retorno às ruas.

Nesse ponto se contrasta as palavras de CECílIO (2006) com as ações de cuidado e atenção à saúde de 
Manu: "a demanda é o pedido mais explícito, a tradução das necessidades mais complexas do usuário". O "vício" e o "alívio" que expressavam a dupla vinculação de Manu à bebida alcoólica, que em parte explicava sua opção pela vida nas ruas e também as relações de amizade que tanto falava, não foram pauta dos atendimentos na policlínica e na clínica da família. Eles foram expressos, porém o foco era a doença que amedrontava e atrofiava suas mãos.

Manu voltou às ruas acompanhada de amigos. Fugiu do itinerário terapêutico que seguia e da família. Mais uma vez desviou - se numa fuga do cuidado, passou a outro caminho. Com os "maloqueiros" seguiu para sua "liberdade".

Desse modo, a última passagem que Manu faz em direção ao espaço que elegeu para viver e reencontrar os amigos, "os maloqueiros", parece expor claramente a extensão que a rede de cuidados em saúde deve buscar. Fugindo da família e da casa, Manu desenha no mapa de seus trajetos um caminho novo onde o cuidado possível pode ser oferecido numa nova estratégia do sistema, 0 Pop Rua ${ }^{6}$, onde as ruas da cidade e a amizade parecem ser tomadas como elementos novos e centrais para as práticas de saúde. As amizades podem ser assim abarcadas no cuidado possível nas ruas da cidade.

Os desencontros na rede de cuidados são mais comuns do que pensamos. Quando deixamos a ligação que une profissionais e usuários esmaecer tende-se a

6 Estratégia de Saúde da Família para População em Situação de Rua/ Consultório de Rua (ESF POP RUA). O projeto "Saúde em Movimento nas Ruas" nasceu na cidade do Rio de Janeiro, em setembro de 2010. Chamado de ESF POP RUA, o serviço é inédito no Brasil, e está em fase inicial de implementação. A ESF POP RUA trabalha integrando duas equipes básicas de PSF (médico, enfermeiro, técnico de enfermagem e seis agentes comunitários de saúde) às equipes de saúde mental (uma assistente social, uma musicoterapeuta e dois psicólogos) e saúde bucal (composta de odontólogo e técnico em saúde bucal). 
ocorrer desencontros, ou seja a rede não se forma, ou se já estendida, tende a se fragmentar, formando linhas soltas que sozinhas não sustentam por muito tempo o cuidado que se busca.

Enquanto acompanhava Manu percebi em vários momentos que algumas consultas ou visitas realizadas pareciam mais desencontros que encontros agendados. Percebi também que esses desencontros eram marcados sempre pelo inverso do encontro: o acolhimento e o vínculo que sustentavam a ligação entre as pessoas eram convertidos em duas palavras que se repetiam continuadamente, conflitos e crise. Ou seja, no desencontro os conflitos e a crise eram na verdade o que desligava a rede, e na maioria das vezes tornavam os momentos tensos e críticos. Nos (des)encontros do cuidado álcool e drogas desligavam a rede e colocavam todo o cuidado em risco, principalmente quando Manu retornou às ruas, em sua fuga do cuidado.

\section{Referências}

BONET, Octávio Andres Ramon. Itinerários de cuidados terapêuticos: histórias, corpos e emoções. REUNIÃO BRASILEIRA DE ANTROPOLOGIA (28.: São Paulo: 2012) [Anais] São Paulo: Pontifícia Universidade Católica de São Paulo, 2012.

BRASIL. DST/AIDS. Departamento de DST, Aisds e Hepatites Virais. Portal sobre aids, doenças sexualmente transmissíveis e hepatites virais. Disponível em: <http:// www.aids.gov.br>. Acesso em: 02 mar. 2013.

CECÍlIO, Luis Carlos de Oliveira. As necessidades de saúde como Conceito Estruturante na Luta pela Integralidade e Eqüidade na Atenção em Saúde. In: PINHEIRO, Roseni; 
MATTOS, Ruben Araújo de. (Org.) Os sentidos da integralidade na atenção e no cuidado à saúde. 4. ed. Rio Janeiro: IMS/UERJ/ CEPESC/ABRASCO, 2006. p. 113-125.

DALMOLIM, Bernadete Maria. Esperança equilibrista: cartografias de sujeitos em sofrimento psíquico. Rio de Janeiro: Editora FIOCRUZ, 2006.

GERHARDT, Tatiana Engel. Itinerários terapêuticos em situações de pobreza: diversidade e pluralidade. Cadernos de Saúde Pública, v. 22, n. 11, p. 2449-2463, 2006.

GOMES, Fabiano Alves (org.) Comorbidades clínicas e Psiquiatria. São Paulo: Ed. Atheneu, 2012.

INGOLD, Tim. Trazendo as coisas de volta à vida: emaranhados criativos num mundo de materiais. Horizontes antropológicos, Porto Alegre, v. 18, n. 37, jun. 2012.

PAES, Marcio Roberto; MAFTUM, Mariluci Alves; MANTOVANI, Maria de Fátima. Cuidado de enfermagem ao paciente com comorbidade clínico-psiquiátrica em um pronto atendimento hospitalar. Revista Gaúcha de Enfermagem, Porto Alegre, v. 31, n. 2, jun. 2010. 


\title{
Entre paradigmas: desafios na constituição de uma política sobre drogas
}

\author{
Ana Cecília Villela Guilhon e Pedro Henrique \\ Antunes da Costa
}

\section{Introdução}

A constituição de uma política sobre drogas implica, nas diversas esferas de governo, interagir com interesses financeiros, eleitorais, religiosos, dentre outros. Neste campo de tensão, aprofundar as discussões teóricas pode ser um bom aliado, possibilitando um olhar crítico e fortalecendo a direção na busca de um trabalho mais consistente. Contudo, uma compreensão mais ampla do tema não parece ser suficiente para dar conta de tal empreendimento e, considerando a complexidade dessa tarefa, a utilização de instrumentos de gestão é fundamental. Através da participação de atores estatais e sociais na construção do Plano Municipal Integrado sobre Drogas do Município de Juiz de Fora, foi possível identificar os principais impasses, desafios e soluções encontradas. Relatando os passos de sua construção, espera-se suscitar possibilidades de construção de políticas e ações em álcool e outras drogas em âmbitos da gestão, mas também em outros cenários, levando em consideração as devidas especificidades. 


\section{A operacionalização do trabalho na gestão: Pensando um plano de ação em álcool e outras drogas}

Em março de 2014, a Prefeitura de Juiz de Fora, através da Secretaria de Governo, iniciou uma série de discussões para tratar da questão das drogas no município. $\mathrm{Na}$ primeira reunião, estavam presentes a secretaria de Governo, representantes de várias secretarias municipais e algumas entidades envolvidas no tema.

A pauta principal deu ênfase às recorrentes notícias sobre o aumento da violência na cidade, publicadas sistematicamente nos jornais locais. As manchetes anunciavam crimes associando jovens às drogas e veiculavam um discurso proibicionista e alarmista, causando sensação de insegurança na população. As discussões foram acaloradas e várias sugestões foram apresentadas. A primeira ideia era de que fosse feito um programa de televisão mobilizando a sociedade civil, em um entendimento que a questão das drogas envolve a todos. Procurar-se-ia desmitificar reducionismos e aspectos referentes ao tema das drogas, como, por exemplo, uma possível causalidade entre o abuso de drogas e a criminalidade recorrente na sociedade, entendendo a temática como uma questão complexa, envolvendo uma série de condicionalidades de natureza social, psicológica, biológica etc.

Outras reuniões se sucederam, agregando mais atores e, sempre em um clima de envolvimento, muitas ideias surgiram, revelando diferentes posicionamentos. Alguns trouxeram exemplos, slogans de campanhas veiculadas como: "O crack mata", "Não desperdice a vida com drogas". Em geral, a reboque do discurso do senso comum, deuse ênfase à família, ao papel da religião, aos infortúnios "causados" pela droga e a uma visão demonizada do crack. Contudo, era premente e sincera a vontade de "fazer alguma coisa". 
Além das novas ideias como concursos de desenhos, frases e redações relacionadas com a temática e direcionados às crianças e adolescentes em fase escolar, começou-se a mapear as ações já realizadas nas diferentes Secretarias Municipais que, de alguma forma, abordavam a questão das drogas. À medida que os programas foram identificados, a percepção sobre a necessidade de se pensar em políticas públicas estruturantes ganhou espaço, sobretudo para potencializar a continuidade das ações e evitar amontoados de ações e iniciativas isoladas. Políticas públicas governamentais e suas formas de organização, como a Rede de Atenção Psicossocial (RAPS), do Sistema Único de Saúde (SUS), e o Sistema Único de Assistência Social (SUAS) foram trazidas ao centro das discussões para fomentar o planejamento de ações. Neste sentido, a proposta da elaboração de um Plano Municipal sobre Drogas, como primeiro passo de uma política pública local, começava a se consolidar.

$\mathrm{Na}$ fase de planejamento, foi agendada uma série de reuniões entre a Secretaria de Governo e as seguintes secretarias: Secretaria de Saúde; Secretaria de Desenvolvimento Social; Secretaria de Esporte e Lazer; Secretaria de Planejamento e Gestão; Secretaria de Desenvolvimento Econômico, Trabalho e Geração de Emprego e Renda; Secretaria de Educação; Secretaria de Agropecuária e Abastecimento; Secretaria de Administração e Recursos Humanos e dos seguintes órgãos da administração indireta: Fundação Alfredo Vieira Lage (FUNALFA) ${ }^{1}$; Departamento Municipal de Limpeza Urbana (DEMLURB); Empresa Regional de Habitação (EmCasa). Foi firmado um compromisso de toda a gestão com as ações relativas ao Plano, que tornou-se uma prioridade de governo. Como forma de aproximar gestão e academia, através de trocas horizontais que possibilitassem maior

1 Responsável pela política cultural do município 
embasamento e contextualidade às ações, a Universidade Federal de Juiz de Fora (UFJF) foi convidada a participar, através do Centro Regional de Referência sobre Drogas (CRR-JF).

Nessa rodada de reuniões foi nomeado um Comitê Técnico, responsável pela consolidação das ações e acompanhamento das atividades. Foram indicados profissionais das Secretarias de Desenvolvimento Econômico, Trabalho e Geração de Emprego e Renda; de Saúde; de Desenvolvimento Social; de Planejamento e Gestão; de Comunicação e, posteriormente, da Secretaria de Administração e Recursos Humanos e Secretaria de Governo. Foram agendadas reuniões semanais propiciando apoio, autonomia e agilidade nas ações.

\section{Formatação do JF+Vida}

O nome Plano Municipal sobre Crack, Álcool e outras Drogas surgiu a partir dos debates nas reuniões, onde o tema estava polarizado entre o mote fácil da luta "contra o crack" e a proposta de oferecer alternativas de lazer, conscientização, geração de renda, etc. num esforço mútuo para implementar políticas públicas que minimizem os espaços onde a droga entra tão facilmente, como os de miséria, falta de oportunidades, ausência do Estado, dentre outros, tão conhecidos em nosso país.

Neste aspecto, a Secretaria de Comunicação Social foi decisiva na divulgação das ações e formatação de um projeto de mídia para o Plano com conceitos visuais e linguagem de contraponto, ainda que minimamente, ao discurso moral e demonizador massivamente reproduzido. Sensível à proposta do grupo, alinhou o nome do plano à 
proposta de comunicação da gestão, cunhando o slogan "JF+Vida" sob o argumento: "não somos contra nada somos a favor da vida!" Lembrando assim o que nos ensina Lancetti: "O conceito de ampliação da vida é uma ponta de lança para desbravar um campo extremamente complexo." (LANCETTI, 2006, p. 85)

O Comitê Técnico reunia-se semanalmente para discutir conceitos, coordenar e consolidar ações, elaborar documentos, organizar eventos e pesquisar iniciativas de outros municípios, além de fomentar discussões. Um bom exemplo foi o Programa de Braços Abertos (PBA), de São Paulo, que reforçou a credibilidade da nossa perspectiva, mas também confundiu alguns aspectos do Plano local. De forma curiosa, iniciou-se a procura de "cracolândias" na cidade com o intuito de fazer uma colagem do PBA para o município, embora as cenas de uso em Juiz de Fora sejam pequenas e mais "distribuídas", sem grande concentração de pessoas. A imprensa local, exageradamente, começou a encontrar "cracolândias" em casas abandonadas, ocupadas por cinco ou seis moradores que, além de estarem em condições sociais extremamente frágeis, também faziam uso de drogas. Em conversas com a imprensa local, nossa discussão começava pelo desmonte de "cracolândias", passava pelo Consultório na Rua e chegava aos postos de saúde, à Estratégia de Saúde da Família e demais propostas estabelecidas nas diretrizes do SUS e SUAS.

Visando a formatação do Plano, que já contava com um nome, constituiu-se um encarte conceitual que incluiu um panorama geral das políticas sobre drogas no Brasil e no Mundo, o objetivo geral do Plano Municipal JF+Vida e conceitos norteadores como: intersetorialidade, território, singularidades, respeito aos direitos humanos e Redução de danos - RD. Nas primeiras discussões a RD era vista como uma estratégia marginal, restrita à troca 
de seringas e substituição de drogas. 0 tema era tratado com certo pudor, evitando-se maiores discussões. Neste ponto, a presença do pesquisador da UFJF foi essencial, pois ocupou um lugar de saber acadêmico contribuindo com as discussões e respaldando as propostas do Comitê Técnico. Além dos conceitos básicos, o encarte conceitual também contemplou uma definição dos eixos de atuação, divididos em Prevenção, Cuidado e Autoridade (inspirado no Programa "Crack, é Possível Vencer"), incluindo, entretanto, outro eixo: Geração de Renda, destacando que o objetivo principal do plano não é apenas levar os usuários mais graves ao tratamento no CAPS ad, mas abrir, para cada pessoa, independente de seu padrão de uso, possibilidades de vida, inclusive de renda, das mais variadas formas. Por fim, o encarte conceitual contou com um glossário de siglas dos mais diferentes setores para ser base de consulta para todos os agentes envolvidos.

Em paralelo, foi criada uma planilha para organizar e facilitar a apresentação da proposta. No cabeçalho constaram as bases do plano: o foco geral da política pública, a gestão, as alianças estratégicas, a comunicação e mobilização social e a educação permanente. Por fim, são nomeadas as ações estruturantes, definindo o foco da política pública em cada eixo de atuação. 
Quadro 1: Eixos de atuação e objetivos do Plano

\begin{tabular}{|c|c|c|c|}
\hline Prevenção & Cuidado & Autoridade & Geração de renda \\
\hline $\begin{array}{l}\text { Institucionalizar } \\
\text { ações de } \\
\text { prevenção nos } \\
\text { serviços; } \\
\text { Tornar os } \\
\text { serviços } \\
\text { públicos } \\
\text { acessíveis a } \\
\text { populações } \\
\text { vulneráveis aos } \\
\text { problemas do } \\
\text { crack, álcool e } \\
\text { outras drogas }\end{array}$ & $\begin{array}{c}\text { Implantar } \\
\text { a Rede de } \\
\text { Atenção } \\
\text { Psicossocial - } \\
\text { RAPS; } \\
\text { Realizar } \\
\text { oficinas } \\
\text { intersetoriais } \\
\text { regionais. }\end{array}$ & $\begin{array}{c}\text { Fortalecer } \\
\text { ações de } \\
\text { inteligência, } \\
\text { investigação } \\
\text { e repressão } \\
\text { qualificada } \\
\text { ao tráfico } \\
\text { de drogas } \\
\text { e crime } \\
\text { organizado, } \\
\text { integrando } \\
\text { diversas } \\
\text { esferas; } \\
\text { Promover } \\
\text { espaços } \\
\text { urbanos } \\
\text { seguros. }\end{array}$ & $\begin{array}{c}\text { Promover } \\
\text { empregabilidade e } \\
\text { empreendedorismo } \\
\text { à população e } \\
\text { usuários de álcool e } \\
\text { outras drogas. }\end{array}$ \\
\hline
\end{tabular}

Fonte: Dos Autores

A partir da definição das ações estruturantes, cada Secretaria Municipal trouxe propostas para os diferentes eixos, que foram elencadas na planilha com colunas designando o responsável e cronograma da ação. Contudo, foram incluídas apenas as ações com objetivos afins com a ação estruturante, dando maior solidez ao plano. 


\section{Lançamento do Plano}

A fase de planejamento possibilitou um alinhamento teórico, um mapeamento das ações realizadas pelas diversas Secretarias Municipais e foram produzidos um encarte conceitual e uma planilha com as principais ações propostas.

O trabalho já ganhava consistência e a divulgação das ações ao público em geral era uma preocupação constante, sobretudo no que diz respeito ao formato e linguagem acessível a todos. Assim, em um delicado fio entre a demanda popular (e midiática) e a proposta de uma política pública bem mais ampliada, a Secretaria de Comunicação precisou trabalhar com cuidado para traduzir esforços e ações discutidas evitando reducionismos e extremismos. Foi necessário driblar soluções higienistas que contam com o dueto drogas-internação e propor alternativas que gerem credibilidade.

Neste esforço, foram preparados dois vídeos para o lançamento do plano: um com entrevistas dos principais atores, deixando clara a proposta do JF+Vida, e outro institucional, em formato de curta. A linguagem do vídeo institucional foi longamente debatida e a profundidade das discussões pautavam-se entre a liberdade de escolha individual e as contingências sociais que a impedem. Além das posições teóricas, que evidentemente determinam as ações e discursos, ficou evidente a dificuldade e, algumas vezes, a impossibilidade de tradução da linguagem acadêmica para midiática. Devido ao árduo trabalho, sobretudo dos profissionais da comunicação, foi possível fazer um vídeo evitando dualismos entre o bem e o mal, o certo e o errado e afastando-se da linguagem de "guerra às drogas". O vídeo trouxe certa leveza, traduzindo a ideia de que há vários caminhos possíveis na vida de cada um. E, 
seguindo a mesma linha, um site com informações também foi criado, dando maior visibilidade ao plano.

De forma concreta, o lançamento do plano envolvia duas etapas distintas: a aprovação no Conselho Municipal de Políticas sobre Drogas e o lançamento para o público. Durante as conversas sobre a escolha da data do lançamento do JF+Vida, foi possível observar efeitos do trabalho anterior nas falas dos envolvidos. A princípio, foi considerada a possibilidade do lançamento em uma marcha de cunho religioso. Porém, com o avanço das discussões tornou-se consenso que o lançamento deveria ser durante a inauguração do primeiro Centro de Atenção Psicossocial (CAPS) do tipo III da cidade, vinculando o Plano Municipal sobre crack, álcool e outras drogas à política de atenção psicossocial. Ainda que pareça evidente que seja assim, sabemos que na prática da gestão nem sempre é simples. Várias forças estão postas no jogo político e ninguém está livre de seus efeitos. Infelizmente, não houve tempo hábil para realizar o lançamento na inauguração do CAPS III. Então, uma nova proposta foi aceita: sancionar o Fundo do Conselho Municipal de Políticas Integradas sobre Drogas (COMPID) e lançar o JF+Vida em um evento único. Desta forma, o COMPID também teve um papel estratégico na constituição do Plano JF+Vida, sendo descrita a seguir.

\section{A Articulação com o COMPID: Abrangendo a participação social}

O COMPID de Juiz de Fora é bem recente, existindo há cerca de um ano e meio, embora seja o resultado de uma luta de muitos anos e de vários atores municipais, sobretudo aqueles vinculados aos direitos humanos. Embora a lei 
municipal que determina a criação do conselho tenha sido sancionada em nove de janeiro de 2012, determinando 60 dias para sua implementação, somente em janeiro de 2014 foi criado um comitê, formado por Secretários Municipais e suplente, para a efetiva criação do COMPID.

A lei municipal $\mathrm{n}$ o 12.468 (JUIZ DE FORA, 2012) determina que o COMPID seja formado por 22 membros, sendo seis governamentais, seis representantes de civis de conselhos locais, nove especialistas e um representante das "casas de recuperação de dependentes químicos". Com este perfil, foi possível agregar atores "especialistas" que haviam participado da luta para a criação do conselho. Assim, ainda que de formação recente, grande parte de seus membros já acumulavam experiência em Conselhos Municipais ou em reflexões sobre o campo relacionado a drogas. Constituído, o Conselho deu seus primeiros passos com a eleição da mesa diretora, a criação do regimento interno, a formação de comissões e a elaboração da proposta para criar o Fundo Municipal sobre Drogas, que havia sido vetado na sanção da lei.

A criação de um Fundo Municipal sobre Drogas pode significar diferentes movimentos políticos, dependendo do município e da composição do Conselho de Políticas sobre Drogas local. Na prática, pode receber recurso revertido de apreensões relacionadas ao tráfico de drogas (BRASIL, 2006), recursos do Tesouro Municipal e doações privadas. O Fundo é sempre vinculado ao Conselho Municipal sobre Drogas, em geral, estes conselhos são chamados de COMADS (Conselhos Municipais Antidrogas) e são instrumentos extremamente poderosos na constituição das políticas municipais sobre drogas e, consequentemente, nas políticas estaduais, através dos Conselhos Estaduais de Entorpecentes (CONENS), e federais através do Conselho Nacional sobre Drogas (CONAD). Ainda que configurem 
um importante instrumento de poder, os conselhos têm sido ocupados por entidades privadas e ONGs, sobretudo religiosas, prevalecendo propostas de tratamento excludentes e moralistas em detrimento de políticas públicas com reflexões mais críticas do tema. Não se questiona a inserção da sociedade e instituições na temática, mas entende-se a necessidade de responsabilização do Estado em prover um cenário assistencial público amplo e de acordo com as necessidades populacionais.

Em Juiz de Fora, foi possível constituir um conselho técnico e crítico, tornando-se um aliado fundamental, tanto no apoio à constituição do Plano Municipal, visando à construção de uma política pública, como no acompanhamento e fiscalização de sua implantação. Como ferramentas administrativas para atingir este objetivo, o JF+Vida foi aprovado no COMPID e posteriormente adotado como plano de ação do conselho. Nesta etapa, foi explicitada a prioridade de investimentos na implementação da RAPS. Além disso, o COMPID aprovou o Plano na condição de que fosse nomeada uma comissão para o seu acompanhamento, responsável por analisar relatórios trimestrais recebidos da Secretaria de Governo. Foi solicitada também a participação de um membro do Conselho em reuniões de implantação do Plano, no intuito de acompanhar ainda mais de perto a realização das ações. 


\section{Alianças Estratégicas}

Realizadas as reuniões de planejamento, estava firmado o compromisso com as secretarias municipais, sendo que no lançamento do Plano JF+Vida tornouse público o compromisso da prefeitura. Destacou-se o controle social, o COMPID, como parceiro estratégico. A partir de então, foram promovidas uma série de reuniões com outros parceiros estratégicos. Nesta fase, foram chamados a polícia civil, polícia militar, Gerencia Regional de Ensino, Centro de prevenção a criminalidade e muitos outros.

Nestas reuniões foram ouvidas as principais demandas e possíveis contribuições dos parceiros. Foram apresentadas as ações realizadas e argumentos críticos em relação ao panorama atual das políticas sobre drogas e possíveis parcerias/saídas a serem construídas.

Durante este período, o comitê técnico discutiu formas de acompanhamento das ações. Foram avaliadas planilhas, softwares e diferentes metodologias. Ao contrário do que se poderia supor, foi grande a quantidade de ações apresentadas, demandando uma melhor avaliação de suas relevâncias, além do georreferenciamento das mesmas. As oficinas intersetoriais foram consideradas como ferramentas de acompanhamento das ações em seus respectivos territórios. Estas oficinas visam propiciar a formação de grupos locais e agregam as ações do poder público, iniciativa privada e comunidade que acontecem em determinado território, empoderando os atores locais. 


\section{O papel das oficinas intersetoriais}

Uma dificuldade normalmente sentida nas esferas públicas de trabalho é a disponibilidade dos profissionais e das chefias para a participação nos projetos propostos. Para driblar esta dificuldade, foi criado um instrumento jurídico interno à prefeitura, nomeando os membros do Comitê Técnico e disponibilizando o tempo destes profissionais para que se dediquem ao JF+Vida. Da mesma forma, ficou estabelecido que cada secretaria indicaria profissionais de referência, em cada um dos territórios, para participarem das oficinas intersetoriais regionais.

A exemplo das primeiras formas de participação popular, as oficinas são compostas de profissionais dos serviços públicos daquele território, preferencialmente chefias, e de lideranças locais. De forma a limitar a quantidade de oficinas, mantendo a cobertura de todo o município, optou-se por dividir o território por área de abrangência dos nove Centros de Referência da Assistência Social (CRAS) existentes. Os participantes das oficinas foram agrupados por CRAS de referência, buscando parceiros para a condução. A UFJF compôs o grupo, através do CRR-JF, e uma Universidade local também juntou-se ao JF+Vida, via projeto de extensão. As demais áreas ficaram a cargo da própria prefeitura.

As oficinas foram propostas em três frentes: capacitação teórica para os atores-chave; mapeamento dos dispositivos mais potentes dos territórios (como reuniões de equipes de serviços da saúde, assistência social, dentre outras, associações, trabalhos de ONGs, instituições religiosas); e as oficinas propriamente ditas, com momentos de conversa quando os atores são ouvidos e propostas são construídas de acordo com cada região. 
A abertura de espaços de "revolução molecular"2, conforme enunciado por Guattari (1985, p. 167), requerem uma difícil negociação no campo da administração e, muitas vezes, se faz necessário "amarrar" metodologias mais restritas, garantindo a previsibilidade das respostas e reduzindo a angústia dos atores da gestão. Assim, foi proposta como metodologia a discussão de "casos clínicos típicos", elaborando propostas terapêuticas de acordo com os recursos de cada território, tendo em vista os já existentes ou aqueles a serem constituídos.

\section{Considerações finais}

O Plano Municipal sobre Crack, Álcool e outras Drogas propiciou a construção de vários mecanismos, produzindo um cenário propício à implantação de uma política pública sobre drogas. O Plano conta com o apoio da gestão, com diversos parceiros estratégicos. Contudo, seu grande desafio é integrar suas ações e seus principais agentes nos serviços, nos bairros, apontando uma política sobre drogas que desfaz a ideia: drogas-tratamento-internação. Nesse sentido, deve-se entender que a formulação do Plano não é fim, mas atividade meio e, que apesar da importância do planejamento, as ações propostas devem ter maleabilidade para se adequar aos contextos e pessoas que abrangem, e não o contrário.

Por fim, espera-se contribuir para que cada trabalhador da rede pública e liderança local possam compreender que a

2 Guattari (1985) propõe duas segmentaridades que atravessam toda sociedade, todo indivíduo, uma molar e outra molecular. Enquanto a primeira diz da macropolítica, grandes conjuntos binários, segmentaridade dura, representações estáticas a segunda diz da micropolítica, segmentaridade flexível, caráter processual, fluxo, multitude. 
questão da droga é muito mais ampla e que há ferramentas interessantes à disposição. Oficinas de teatro, times de futebol, grupos de dança, uma conversa, um engajamento político, uma oportunidade de renda, a melhoria da praça, a escola, assim como as ações de saúde (sejam na Unidade Básica de Saúde, nos CAPS, ou em outros dispositivos), são todos instrumentos na construção da política sobre drogas. Apesar do presente trabalho focar na construção de ações por atores estatais, através de estruturas participativas e dialógicas que integrem diferentes atores sociais, acreditase ser possível devolver a centralidade da saúde para os próprios usuários, através de seu empoderamento e fortalecimento.

\section{Referências}

BRASIL. Casa Civil. Lei 11.343, de 23 de agosto de 2006. Brasília: Casa Civil, 2006.

GUATTARI, F. Revolução Molecular: pulsações políticas do desejo. São Paulo: Ed. Brasiliense, 1985.

JUIZ DE FORA. Lei 12.468, de 09 de janeiro de 2012. Juiz de Fora: Prefeitura Municipal, 2012.

LANCETTI, A. Clínica Peripatética. São Paulo: Hucitec, 2006.

Os conteúdos do texto são responsabilidade dos autores, que participaram do processo de elaboração do Plano, e podem não refletir as concepções da Prefeitura de Juiz de Fora. 



\section{O programa De Braços Abertos da prefeitura paulistana: surgimento, consolidação e perspectivas}

Ygor Alves

\section{Introdução}

"Quem inventou o Braços Abertos fui eu". Esta frase foi ouvida por este pesquisador ao conversar com um beneficiário, termo utilizado pela Prefeitura do Município de São Paulo (PMSP) para se referir aos incluídos no programa De Braços Abertos (DBA). Trata-se de um usuário de crack de trato razoavelmente difícil; ele às vezes mostrase violento, mas orgulha-se de ter participado das reuniões preparatórias para a implantação do DBA com o prefeito Fernando Haddad. Antes do programa, eles viviam na Cracolândia sob o peso do estigma do zumbi morto vivo. (BOES, 2011) Infelizmente, este estigma ainda se encontra presente em publicações recentes:

Os usuários, reunidos em bandos, começaram a assombrar primeiramente as noites de São Paulo. Eram amontoados de gente suja, descabelada, que vagavam catatônicos no que pareciam guetos de morte. Quem acompanha as histórias de ficção sobre zumbis viu logo uma 
associação muito fácil entre os usuários e os "mortos vivos" das sagas do cinema e da literatura. (ROTENBERG, 2013, p. 13)

Após a implementação do DBAesta visão estereotipada começa a perder importância para uma nova maneira de encarar o usuário de crack, mais humana. Até o melancólico ocaso da gestão Kassab frente à PMSP a certeza corrente era da incapacidade generalizada entre os usuários de crack - retratados como zumbis - de exercer sua vontade. O DBA, gestado em encontros destes usuários diretamente com o prefeito da maior cidade do país, veio propor justamente o reconhecimento desta vontade.

Os encontros entre os beneficiários e o prefeito permanecem existindo, ampliados pela participação de lideranças de movimentos sociais, entidades de classe e técnicos responsáveis por um programa em permanente construção. Seu início, em meados de 2013, foi marcado pela determinação em se contrapor às políticas pautadas pela repressão e pela internação em comunidades terapêuticas, muitas vezes de forma involuntária e até mesmo compulsória, levadas a frente pelo governo do Estado de São Paulo, particularmente na gestão Geraldo Alckmin.

\section{Quem? Ou melhor, como se 'inventou' o De Braços Abertos}

O DBA data da elaboração do Plano de Governo "Um tempo novo para São Paulo" do então candidato a prefeito Fernando Haddad. Assim, um plano de intervenção positiva no bairro da Luz foi traçado no sentido de levar cuidado, assistência e dignidade aos usuários de crack. 
Um importante sinal de seu caráter diferenciado foi ter a coordenação do Grupo Executivo Municipal (GEM), responsável pela concepção e implantação do programa, sob a responsabilidade da Área Técnica de Saúde Mental, Álcool e Drogas da Secretaria Municipal de Saúde (SMS). Neste sentido, os hoje beneficiários do DBA tem sua situação cotidiana considerada e avaliada prioritariamente sob a perspectiva da saúde. Em primeiro plano encontramse - além da SMS - a Secretaria Municipal de Assistência e Desenvolvimento Social (Smads), a Secretaria Municipal de Direitos Humanos e Cidadania (SMDHC), a Secretaria Municipal do Desenvolvimento, Trabalho e Empreendedorismo (SDTE) e a Secretaria Municipal de Segurança Urbana. Esta última com presença decrescente na gestão local do programa, segundo declarações de técnicos presentes desde sua implantação, com quem pudemos dialogar. Recentemente, a Secretaria do Governo, na figura do ex-subprefeito do bairro da Sé, Maurício de Gois, juntou-se à coordenação mais próxima do DBA. Esta Secretaria está responsável, por exemplo, em agilizar questões orçamentárias em contato direto com o prefeito. Em um segundo plano vem as secretarias de cultura, esporte e educação.

O DBA nasce sob o espírito da 5a Conferência Municipal de Políticas de Atenção às Drogas (Compad), realizada pela SMDHC, pelo GEM e Conselho Municipal de Políticas Públicas de Drogas e Álcool (Comuda). A conferência foi precedida por reuniões preparatórias abertas feitas por representantes dos três entes municipais acima, nas regiões leste, oeste, sul e central da cidade. A importância da articulação intersetorial foi uma das propostas da conferência, do mesmo modo como a composição do Consultório na Rua com "redutores de danos, equipe de saúde mental articulada com assistência social" (SÃO PAULO. ASSESSORIA ESPECIAL DE POLÍTICAS PÚBLICAS SOBRE DROGAS, 2013, 
p. 5), a importância de uma ideia de cuidado não focada apenas na internação, a promoção do matriciamento entre as redes responsáveis pelo atendimento aos usuários de drogas e a capacitação dos profissionais ligados à política sobre crack, álcool e outras drogas. Nas pré-conferências de Saúde Mental, DST/HIV/AIDS e Saúde da População negra, as preocupações constantes no desenho do DBA estavam presentes também, como trabalhar em uma estratégia de redução de danos (RD), os Consultórios na Rua e a ação intersetorial com presença de cultura, esportes, geração de renda e emprego. (SÃO PAULO. SECRETARIA MUNICIPAL DE SAÚDE, 2013)

A ação intersecretarial destinada a ofertar abrigamento, tratamento de saúde, alimentação, atividade ocupacional, capacitação profissional e auxílio financeiro aos beneficiários incluídos na execução de serviços de zeladoria nas ruas do bairro da Luz teve início dia 14 de janeiro de 2014. Após dois dias, todos os cento e quarenta e sete barracos distribuídos entre as ruas Dino Bueno e Helvétia - local onde hoje se centraliza a Cracolândia - haviam sido retirados. A não construção de mais barracos no local foi pactuada entre a PMSP e os futuros beneficiários do DBA. $A$ adesão ao programa foi da totalidade dos ocupantes dos barracos e se deu nos dias anteriores, ao serem contratados pelo Programa Operação Trabalho (POT) da SDTE para trabalharem em atividades de zeladoria na região, ocupação pela qual passaram a receber um auxílio financeiro no valor de $\mathrm{R} \$ 15$ por dia de trabalho, incluindo os finais de semana para os assíduos. Esta forma de contratação é uma adaptação do POT e compreende um valor de auxílio pecuniário mensal de $\mathrm{R} \$ 450,00$ por 20 horas semanais de trabalho, ou quatro horas diárias nos chamados dias úteis. O POT prevê o investimento total de um salário mínimo e meio por beneficiário. Como custo para a PMSP há também o pagamento das vagas em hotéis da região e alimentação 
correspondente a três refeições diárias no restaurante Bom Prato, programa do governo estadual responsável por fornecer refeições a um real em restaurantes geridos por Organizações Sociais, localizado na Rua Dino Bueno; também os cursos de capacitação já ofertados a partir de aptidões e demandas dos beneficiários e o pagamento da equipe de técnicos e orientadores, assim como dos gestores do serviço: a organização não governamental Brasil Gigante, a serviço da SMDHC. Em setembro de 2014 a Brasil Gigante foi substituída pela Associação de Desenvolvimento Econômico e Social às Famílias (Adesaf) após processo licitatório.

\section{A Frente de Trabalho e o Trio}

A Brasil Gigante gerenciava a frente de trabalho, parte do DBA. Até então dedicada à gestão de creches e abrigos para crianças e adolescentes, assim como de um telecentro, esta ONG foi contratada em caráter emergencial para gerir o programa em seus primeiros seis meses. Uma licitação foi aberta para a contratação de entidade gestora a partir deste período, a Adesaf. Em contato com a Brasil Gigante pudemos acompanhar o trabalho das equipes no trecho, como é chamado o caminho percorrido por cada equipe nos arredores do bairro dos Campos Elíseos.

Após acordarem e saírem do hotel, os beneficiários se dirigem ao restaurante do Bom Prato, localizado na Rua Dino Bueno para tomarem o café da manhã. A entrada no restaurante é possibilitada por um crachá distribuído pelo orientador social a cada um de sua equipe de vinte beneficiários. Dificilmente a equipe estará completa, os ausentes serão objeto de busca ativa por parte dos quarenta e quatro orientadores socioeducativos de Smads 
e agentes comunitários de saúde da SMS. As informações sobre a ausência no trabalho para a posterior busca ativa são obtidas por estes profissionais após o café da manhã, no local de saída das equipes. Em seguida, os agentes sociais de Smads e agentes comunitários de saúde responsáveis por cada grupo de vinte beneficiários se dirigem aos hotéis para visitá-los e verificar os motivos da ausência na frente de trabalho. Entre treze e catorze horas, o trio composto pelos agentes sociais de Smads, agentes comunitários de saúde da SMS e orientadores sociais até então, da OBG se reúne para discutir as diversas demandas surgidas. Esta rotina passou a ser implementada pouco mais de um mês após o início dos serviços de zeladoria feitos por parte dos beneficiários. Antes, cada trio, como é chamado o grupo responsável por uma equipe, se encontrava e resolvia as demandas individuais de modo informal. Os agentes comunitários de saúde são os únicos não disponíveis na proporção de um por grupo de vinte, mas apenas um por hotel onde se hospedem beneficiários.

A busca ativa é feita dentro dos hotéis com os membros do trio indo de porta em porta. Ao final do mês de fevereiro de 2014, apenas duzentos entre quatrocentos e vinte e nove participantes do DBA se dedicam aos serviços de zeladoria, alguns jamais apareceram para trabalhar, outros desistiram pelos mais diversos motivos, como os de saúde. Em meados de abril, este número havia subido para duzentos e noventa e três beneficiários participando ao menos uma vez naquele mês. Há casos de nomes constando nas listas das equipes de vinte beneficiários, mas as pessoas nunca apareceram para trabalhar, assim como de inscritos na primeira fase do programa ressurgindo após três meses de sua implantação. Em todo caso, não há exclusão do programa, dada sua baixa exigência, ou exigência apropriada. Mesmo com meses de ausência, eles são incluídos. 
Os membros das equipes citadas acima originalmente trabalhavam apenas em um mesmo hotel. Contudo, devido à necessária flexibilidade exigida pelas características dos beneficiários, há uma considerável flutuação deles entre os apartamentos e mesmo entre os hotéis. Isto se dá pelos mais variados motivos, desde separações de casais, passando pelo desejo de ter uma acomodação melhor, até a simples curiosidade de conhecer e se alojar em quarto ou hotel diferente. Assim, os trios devem dar conta de vinte beneficiários distribuídos nos mais variados hotéis. Isto marca um dos pontos fortes do programa: o atendimento integrado, individualizado e integral ao beneficiário, proporcionado pelo trabalho de profissionais ligados às áreas de saúde, assistência e trabalho em contato diário.

Os antigos moradores destes barracos, por sua vez, tentam adaptar o quarto de hotel à vida costumeira no barraco e, ao mesmo tempo, mudam o estilo costumeiro de ocupação de um hotel para melhor adaptá-lo ao seu modo de vida em transição. Por exemplo, ocupam os corredores e escadas para conversas e lazer, flutuam entre os quartos e prédios e alugam vagas para terceiros nos finais de semana, quando não há acompanhamento dos agentes sociais de Smads. Estes estão presentes todos os dias úteis na portaria e procuram estabelecer certo controle sobre a ocupação dos quartos. A flutuação não se dá livremente, mas por via de pedidos às agentes sociais e particularmente a uma assistente social com larga experiência na região. Esta assistente social conhece pelo nome ou apelido praticamente a totalidade dos beneficiários que são antigos moradores ou frequentadores assíduos da Cracolândia.

Existe uma preocupação dos técnicos, particularmente da saúde mental, em garantir que nos encaminhamentos dos beneficiários todos se atentem às diferenças entre os serviços oferecidos pela PMSP e pelo Governo do Estado, 
bem como da importância de se referenciarem nos serviços municipais e não nos oferecidos pelo poder estadual. Como vimos acima, grosso modo poderíamos considerar os serviços estaduais como dando certa prioridade à internação em comunidades terapêuticas (CT), enquanto a PMSP priorizaria os Centros de Atenção Psicossocial (CAPS). São cinco CAPS na rede de abrangência do DBA, dois CAPS-AD III, um CAPS infantil, um CAPS adulto e o Centro de Referência de Álcool, Tabaco e Outras Drogas - Cratod, este último também possuindo um CAPS, além de outros serviços. Isto não impede a abordagem de beneficiários, assim como dos demais frequentadores da Cracolândia, por agentes sociais do Instituto Mensageiros para encaminhamento a comunidades terapêuticas, através do Programa Recomeço (PR), do governo estadual. Porém, caso um destes abordados necessite de tratamento ambulatorial, ele é normalmente conduzido pelos agentes sociais do PR aos CAPS da prefeitura. Da mesma forma, caso algum beneficiário do DBA chegue juntamente com a equipe multidisciplinar em contato com ele à decisão por uma internação em clínica de recuperação ou CT, ele será encaminhado ao PR. Este tipo de relacionamento existia antes da implantação do DBA inclusive; apenas posteriormente, após sua inauguração, foi objeto de acordo formal entre os entes estadual e municipal.

Por estarem hospedados em hotéis e trabalhando meio período, os beneficiados são obrigados a se adaptar ao novo ambiente físico, mas também procuram se servir de novas possibilidades abertas pelo DBA. Assim, nas semanas iniciais do programa, chegaram a alugar seus quartos para encontros e pernoites para aqueles frequentadores da Cracolândia não incluídos no DBA, assim como vender uniformes a cinquenta reais e botas a sessenta, a negociar cartões de alimentação e até os documentos de identidade retirados por Smads. Todos estes fatos são de conhecimento 
dos gestores do DBA - principalmente da SDTE e Smads e em resposta eles procuram os mecanismos de controle possíveis de serem adotados. Por exemplo, uma carteira de identificação dos beneficiários foi confeccionada, embora esbarre na aversão de parte deles por fotografias, devido a uma parcela deles ter pendências com a justiça. Isto levou a Smads a procurar a defensoria pública do estado, para tratar de assessorar juridicamente aqueles dispostos a resolver suas altercações jurídicas.

\section{A Tenda}

O PBA possui sede própria independente da sede alugada inicialmente pela OBG no Largo Coração de Jesus, localizando-se a dois quarteirões desta, quase na esquina das ruas Helvetia e Cleveland. É uma construção modesta, separada da rua por uma grade e dotada de portão também gradeado. Possui uma tenda de aproximadamente cento e vinte metros quadrados e uma pequena edificação com uma sala de reuniões, cozinha e banheiros para os funcionários e outros dois banheiros usados normalmente pelos beneficiários e demais usuários de crack frequentadores do fluxo, ou local de uso de crack localizado em frente à Tenda. Lá trabalham cinco profissionais da administração direta, responsáveis por gerenciar todas as ações vinculadas à SMS. Esta sede serve de ponto de apoio para três equipes do Programa de Agentes Comunitários de Saúde (PACS), compostas por dez agentes cada e um enfermeiro por equipe: eis a 'Tenda'. É um local para uso das equipes de saúde e assistência e também uma área de lazer para os frequentadores da Cracolândia.

Ao observar o dia a dia de funcionamento da Tenda 
testemunhamos dezenas de atendimentos dos mais variados tipos, realizados nas diversas mesas a mobiliar 0 local. Desde pessoas a procura de atendimento médico, até usuários de crack em busca de auxílio para retornar para casa. A maior parte das equipes da saúde é oriunda de convênio com a Associação Saúde da Família, uma ONG surgida no início dos anos noventa, a partir de financiamento norte-americano e presidida pelo ex-ministro Adib Jatene. Há também uma equipe com treze profissionais do Consultório na Rua, uma equipe do CAPS na Rua composta por oito profissionais dos quatro CAPS da região, e uma equipe de quatro acompanhantes terapêuticos do Projeto Quixote (exclusiva para crianças e adolescentes). Eles têm entre outras responsabilidades as de abordar as crianças e adolescentes em situação de rua no sentido da aproximação e criação de vínculo não apenas pelo diálogo, mas também pelo encaminhamento e acompanhamento destes jovens e crianças aos serviços que se revelarem necessários; além de realizar atendimentos nos hotéis vinculados ao DBA e qualquer outro domicílio onde este público possa encontrar-se. Todas as informações são inseridas em um "prontuário" individualizado.

\section{De Braços Abertos: realizações, limitações e perspectivas}

No momento da elaboração deste trabalho, um confronto entre policiais e usuários de crack ocorre em frente ao DBA. O programa surgiu com a retirada de 147 barracos e este fato marcou de modo indelével não apenas seu início, mas o limite do politicamente possível e aceitável por parte da prefeitura. O confronto entre a Tropa de Choque da Polícia Militar comandada pelo Governo do Estado e os usuários de crack - beneficiários e não beneficiários do DBA 
- deu-se na manhã de dezoito de setembro de 2014, em virtude do desmonte de barracos montados no fluxo, em frente ao DBA. Portanto, a baixa exigência do DBA encontra um limite político: a remontagem dos barracos. Eles não são um problema de saúde, tão pouco de segurança pública, mas um objeto de exploração midiática. Ao surgirem os barracos na segunda metade do ano de 2013, a mídia explorou o fato a exaustão. Uma matéria publicada por Yarak \& Monteiro (2014) no jornal Folha de São Paulo é um exemplo deste tipo de cobertura midiática. Nela, os moradores dos barracos declaram ter de pagar $\mathrm{R} \$ 30,00$ para usá-los.

Porém, para o usuário de crack o barraco é um local seguro e confortável para o uso da droga e também para seu comércio. $\mathrm{O}$ barraco proporciona a intimidade negada pela situação de rua e abriga contra o frio da noite e o sol diurno. Não faltam vagas no DBA, mais cento e cinquenta novas vagas foram abertas, além das quatrocentas e vinte e duas existentes e a prefeitura espera vê-las preenchidas em breve. Do ponto de vista da administração municipal, o barraco é local propício ao tráfico e objeto de exploração midiática/política. Ele fica fora do campo de visão das câmeras do micro-ônibus de vigilância fornecido pelo governo federal através do programa Crack, é possivel vencer e localizado próximo ao fluxo. $\mathrm{O}$ barraco é um ponto cego e a não construção de novas unidades havia sido pactuada no início do programa em reuniões do prefeito com representantes dos frequentadores da Cracolândia.

Apenas os desconhecedores da dinâmica do uso do crack podem defendera ideia de salas de uso para o craqueiro. O crack não é uma droga cujo consumo é separado por períodos de várias horas como a heroína, droga para quem as salas de uso foram criadas. Neste caso, o da heroína, se faz necessário um local limpo para aplicação com seringa e 
agulha hipodérmica e o usuário irá retornar apenas algumas horas depois para novo uso. Nada mais diferente do crack. Este é usado a intervalos de quinze minutos em média e o cachimbo é um meio seguro de utilização da droga quando não compartilhado. O usuário não dá um trago e se retira do local, mas lá permanece interagindo animadamente com os outros na roda de crack. O fluxo em frente ao DBA é um local ideal de uso basta acrescentar-lhe alguns poucos mobiliários urbanos como os já programados pela PMSP, bancos e floreiras, além disto, poderiam se acrescentar toldos para se defender do sol sem atrapalhar a visibilidade das câmeras. Considerando elas também serem garantia quanto à violência policial injustificada. Alguns técnicos da prefeitura também cogitam lá instalar bebedouros, e um espaço aberto para enfermaria.

Mudanças importantes trarão algumas correções de rumo significativas no programa. A primeira delas foi a licitação para contratação de nova entidade responsável pela gestão dos contratos com hotéis e do POT no lugar da Brasil Gigante contratada em caráter emergencial. Uma maior fiscalização da ocupação dos hotéis é prometida pelo prefeito para breve (SÃO PAULO. SECRETARIA EXECUTIVA DE COMUNICAÇÃO, 2014a) com um controle maior da entrada e saída de pessoas, assim como, a separação das famílias com crianças das demais. A descentralização e replicação com adaptações do programa foram iniciadas nas regiões de Vila Mariana, Lapa, Santo Amaro, Santana e Cidade Tiradentes. (SÃO PAULO. SECRETARIA EXECUTIVA DE COMUNICAÇÃO, 2014b) Algumas portas de saída se vislumbram pelo caminho do trabalho, como a contratação de dezesseis beneficiários por uma prestadora de serviços da prefeitura, e a também contratação de outros dezoito em frentes de trabalho municipais, além dos doze já trabalhando fora do POT. No serviço de varrição, ou zeladoria do bairro são duzentos e vinte e oito beneficiários e sessenta e seis 
estão na Fábrica Verde ${ }^{1}$ montada no Complexo Prates, um importante equipamento destinado a população em situação de rua. (SÃO PAULO. SECRETARIA EXECUTIVA DE COMUNICAÇÃO, 2014b)

\section{Referências}

ASSESSORIA ESPECIAL DE POLÍTICAS PÚBLICAS SOBRE DROGAS. Propostas para o V Compad. In: Portal da Prefeitura do Município de São Paulo. Disponível em: http://www. prefeitura.sp.gov.br/cidade/secretarias/direitos_humanos/ politica_sobre_drogas/noticias $/ \mathrm{p}=159635$. Acesso em: 16 abr. 2014.

BOES, G. M. "Crack, nem pensar": um esboço sobre mídia e política criminal. Porto Alegre: PUCRS, 2011. Dissertação de mestrado.

ROTENBERG, M. Crack: um novo olhar. Disponível em: http://www.cieds.org.br/docs/publicacao-crack-um-novoolhar-.pdf. Acesso em: 27 maio 2014.

SÃO PAULO. SECRETARIA DO DESENVOLVIMENTOTRABALHO E EMPREENDEDORISMO. Fábrica Verde. In: Prefeitura de São Paulo. Disponível em: http://www.prefeitura.sp.gov.br/ cidade/secretarias/trabalho/empreendedorismo/fabrica_ verde/index.php?p=38588. Acesso em: 19 set. 2014.

\section{. SECRETARIA EXECUTIVA DE COMUNICAÇÃO.}

Mães que moram em hotéis da Nova Luz temem exposição de filhos. In: Prefeitura de São Paulo. Disponível em: http:// www.capital.sp.gov.br/portal/noticia/3658/. Acesso em: 18 set. 2014a.

1 A Fábrica Verde fornece cursos profissionalizantes na área da jardinagem, paisagismo e permacultura urbana. (SECRETARIA DO DESENVOLVIMENTO TRABALHO E EMPREENDEDORISMO, 2014) 
. SECRETARIA EXECUTIVA DE COMUNICAÇÃO.

Criminalidade cai na Cracolândia após ações do programa De Braços Abertos. In: Prefeitura de São Paulo. Disponível em: http://www.capital.sp.gov.br/portal/noticia/3592. Acesso em: 18 set. 2014 b.

SECRETARIA MUNICIPAL DA SAÚDE.

Relatórios Consolidados das Pré-Conferências. 2013. Disponível em: <http://www.prefeitura.sp.gov.br/cidade/ secretarias/upload/Pasta\%20PDF\%20Portal\%20R/ RelatoriosConsolidados_PreConferencias_2013.pdf>. Acesso em: 16 abr 2014.

SECRETARIA MUNICIPAL DE DIREITOS

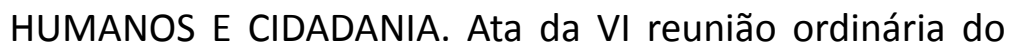
comitê intersetorial da política municipal da população em situação de rua. In: Portal da Prefeitura da Cidade de São Paulo. Disponível em: <http://www.prefeitura.sp.gov. br/cidade/secretarias/upload/direitos_humanos/Ata\%20 da\%20VI\%20Reuniao\%20Ordinaria\%20Comite\%20\%20 02_10_2013.pdf>. Acesso em 16 abr 2014.

YARAK, A.; MONTEIRO, A. Moradores dizem que pagam R\$ 30,00 por barraco na cracolândia. Folha de São Paulo, São Paulo, 15 jan. 2014. Disponível em: http://www1.folha.uol. com.br/cotidiano/2014/01/1397980-moradores-dizemque-pagaram-r-30-por-barraco-na-cracolandia.shtml. Acesso em: 18 set 2014. 


\section{O apoio institucional na implantação de estratégias de redução de danos: por quê e para quê?}

Marcelo Dalla Vecchia

\section{Por que apoio institucional?}

Com a reabertura democrática que tem 0 ano de 1985 como marco, e mesmo ainda durante as lutas prévias por esta reabertura, evidenciou-se que os 20 anos de ditadura civil-militar no país foram um retrocesso na busca por constituir ações de saúde pública. (FLEURY, 1997) Neste contexto, em que se arregimentam forças sociais e políticas em torno da construção de um sistema de saúde único, universal e no qual o direito à saúde seja um aspecto inalienável, evidenciou-se uma singularidade importante aos atores políticos da proposta brasileira de reforma sanitária. (PONTE; FALLEIROS, 2010) O debate acerca a necessidade de uma nova concepção de saúde, abrangendo a integralidade das ações de promoção, prevenção, recuperação e reabilitação, incorporando mas não restringindo a produção da saúde à assistência médica, precisava atingir as peculiaridades da gestão pública. Uma cultura política coronelista, patrimonialista e clientelista, que exclui na prática a maior parte da população da 
participação nas decisões, inclusive acerca dos modos pelos quais se gere o cuidado à sua própria saúde, levaram à problematização das formas pelas quais se deve operar a gestão do sistema, incidindo diretamente em como se apresenta a oferta assistencial.

Ao analisar o caso da expansão da atenção básica, ocorrida desde fins dos anos 1990 por meio da Estratégia de Saúde da Família (ESF), Conill (2008) aponta que, rigorosamente, nos momentos iniciais da implantação do Sistema Único de Saúde (SUS), a balança pendeu de forma notável para preocupações em torno da gestão do sistema, ou seja, para os aspectos "macro": organização dos serviços, financiamento e instrumentos de gestão. Neste meio tempo, a preocupação com as transformações assistenciais necessárias para contemplar a nova concepção de saúde consignada pelo SUS permaneceu em segundo plano. Aparentemente, as maiores inovações assistenciais neste sentido somente se consolidaram em âmbito subsetorial. É o caso das ações de atenção psicossocial, que problematizaram um conceito preventivista de "saúde mental", e das ações voltadas ao cuidado de pessoas com DST/HIV/Aids, que introduziram a perspectiva da redução de danos. Neste mesmo processo, foram ganhando contornos a experimentação de mudanças por meio da construção de distintas propostas que, de algum modo, buscaram interferir na oferta técnico-assistencial em saúde, tais como Cidades Saudáveis, Em Defesa da Vida, Ações Programáticas e Vigilância da Saúde. (TEIXEIRA, 2003)

Ainda no que tange à atenção básica, a questão da universalização da assistência ganha projeção nacional e destaque no cenário das políticas públicas com a introdução da ESF como proposta para a reorientação das ações de saúde neste nível de atenção. Interessante notar que há uma certa expectativa de que a maior cobertura assistencial impacte positivamente, e de forma imediata, nos níveis de 
saúde de uma população. No entanto, desde pelo menos a primeira década do século XXI, os próprios trabalhadores, as gestões municipais e a intelectualidade vêm destacando, dentre outros aspectos, que uma maior resolubilidade dos problemas de saúde por parte da ESF será central para a sua consolidação. Não que esta resolubilidade seja menos importante em outros pontos da rede, porém, quando se indica que a atenção básica em saúde, quando bem estruturada, teria condições de acolher com efetividade a imensa maioria dos problemas de saúde, a questão da resolubilidade torna-se central. (BRASIL, 2012)

Assim, há um reconhecimento crescente de que, para além da universalização e do acesso geográfico - desafios que persistem - a qualificação das ações assistenciais é uma questão nevrálgica para o SUS, o que requer não somente uma ampliação quantitativa da oferta, quanto pautar, também, sua forma e seu conteúdo. Neste sentido, alguns princípios vêm sendo trazidos à tona: (a) a integralidade das práticas permitiria ampliar a concepção de processo saúdedoença para abarcar dimensões do adoecimento que transcendem o modelo biomédico, (b) a intersetorialidade possibilitaria dar visibilidade à necessidade de articulação de ações de vários setores das políticas públicas (assistência social, lazer, educação, transporte etc.) para a melhoria das condições de vida e saúde da população, e (c) a equidade enfatizaria o requisito de que o sistema organize-se para oferecer maiores recursos aos segmentos mais marginalizados e excluídos da oferta em saúde. A operacionalização destes princípios, incontestavelmente, requer que se levem em consideração aspectos da gestão em âmbito macro ou micro do sistema de saúde.

Assim, no contexto atual da reforma sanitária, e visando à consolidação do SUS, é imprescindível considerar gestão e assistência como dimensões interdependentes ou, em outras palavras, é preciso tratar clínica e política como 
aspectos intrínsecos à oferta assistencial. Ao atuar como um catalisador de um conjunto de propostas desta natureza, entende-se que a PNH representou um ponto de inflexão importante da reforma sanitária brasileira. (BRASIL, 2008) O apoio institucional, que passaremos a definir a seguir, é considerado um dos dispositivos fundamentais da $\mathrm{PNH}$.

\section{O que é apoio institucional?}

É corriqueiro que certo discurso demagógico afirme a importância do protagonismo do trabalhador da saúde, enquanto as relações de poder no trabalho terminem por colocá-lo em uma posição de passividade e heteronomia com relação ao planejamento e realização de seu próprio trabalho. O discurso do "trabalho em equipe", muito bem apropriado pela maior parte dos gestores, é outra face do mesmo problema, quando a fragmentação do trabalho, o corporativismo profissional e o autoritarismo das chefias ainda é persistente. (DALLA VECCHIA, 2012)

A Política Nacional de Humanização da Assistência Hospitalar no SUS converte-se em Política Nacional de Humanização (PNH) no ano de 2003, passando a abranger não somente os hospitais mas todos e quaisquer espaços que operam políticas de saúde. Trata-se de investir na "mudança dos modelos de atenção e gestão fundados na racionalidade biomédica (fragmentados, hierarquizados, centrados na doença e no atendimento hospitalar)." (SANTOS FILHO; BARROS; GOMES, 2009, p. 604) Como parte dos seus dispositivos, o apoio institucional é considerado um "instrumento relevante na tarefa de promoção do exercício político público no âmbito do SUS" (GUEDES; ROZA; BARROS, 2012, p. 94), ratificando a potência coletiva 
do público. Busca estimular a criação de espaços coletivos, reconhecer as relações de poder, de afeto e a circulação de conhecimentos no cotidiano do processo de trabalho.

Alguns autores buscam conceituar 0 apoio institucional. Para BARROS; GUEDES; ROZA (2011, p. 4805), o "apoio institucional é uma estratégia de fomento à gestão compartilhada dos processos de trabalho exercida nas práticas cotidianas concretas e que parte da premissa de que todo trabalhador é gestor de seu trabalho". Para isso, o apoio institucional introduziria uma "intervenção-oferta para ajudar a ressignificar a compreensão do serviço e suas bases de organização." (SANTOS FILHO; BARROS; GOMES, 2009, p. 606)

Operar a indissociabilidade entre gestão e assistência à saúde, ou, em outras palavras, entre clínica e política no cotidiano do cuidado, não pode ser imposto com o estabelecimento de metas, produtos e prazos pré-fixados, ou seja, não é somente uma questão "técnica". Neste sentido trata-se também de uma questão ético-política, visto que

A atividade de trabalho é sempre marcada pela relação dramática entre autonomia e heteronomia. Trabalhamos sempre em meio a negociações, escolhas e arbitragens, nem sempre conscientes, que consideram o tipo de inserção de cada um e de todos que compartilham aquele meio de trabalho, mas, também, as políticas de saúde, os valores e as práticas de saúde instituídos, as relações de forças e de poderes presentes em cada situação de trabalho. Enfim, todos nós somos corresponsáveis pela gestão das situações de trabalho e temos o potencial de ajudar a transformá-las ou mantê-las como estão. (SANTOS FILHO; BARROS; GOMES, 2009, p. 610) 
É preciso pôr em discussão a função do apoiador institucional neste processo. $\mathrm{O}$ apoiador desenvolve uma prática específica: coloca-se ao lado dos trabalhadores na análise de seu processo de trabalho, assumindo a impossibilidade de fazê-lo por eles, ou em nome deles. Ao ocupar este lugar, o apoio institucional configura-se como uma função gerencial, mas que rompe com a perspectiva de uma supervisão administrativa. (VASCONCELOS; MORSCHEL, 2009) Neste sentido, o apoiador institucional recusa a imposição de certos protocolos ou normas, passando a considerar os efeitos dos dispositivos que aciona, negando, também, o conforto da posição de um consultor externo, implicando-se com a organização do processo de trabalho e com os espaços coletivos que compõem a análise-intervenção. (BARROS; GUEDES; ROZA, 2011)

Recusa-se, neste sentido, ao mandato de tutela e deslegitimação do outro usualmente concedido àqueles que ocupam postos de chefia e coordenação dos processos de trabalho. (SANTOS FILHO; BARROS; GOMES, 2009) Investe-se em uma comunicação lateralizada, entre diversos setores e especialidades, no lugar de comunicações verticais (chefe-subordinado), ou entre iguais (corporativa). Gerar inflexões nos modos de produzir saúde no cotidiano depende da construção de negociações, diálogos e da criação de alternativas, ainda que com base em acordos inicialmente rudimentares, mas que, ao indagar relações de poder, podem romper com o isolamento e ativar mudanças. (GUEDES; ROZA; BARROS, 2012)

Nesta oportunidade, são relatados alguns episódios referentes a uma experiência de apoio institucional elaborada junto da Coordenação de Saúde Mental de Barbacena/MG para colaborar nos projetos de implantação do Consultório de Rua (CR) e da Escola de Redutores de Danos (ERD), no decorrer dos anos de 2012 e 2013. O 
que está sendo denominado aqui de "episódio" trata-se nada mais do que a narrativa de situações significativas ocorridas nas atividades de apoio institucional. Salientamse possíveis efeitos na própria atividade de apoio, na gestão do processo de implantação ou no cotidiano das ações de redução de danos desenvolvidas pelas equipes. Ressaltamse as possíveis contribuições do apoio institucional como um dispositivo que possibilita uma análise em ato do processo de implantação de ações de cuidado em saúde, em especial, de redução de danos.

\section{Para que o apoio institucional?}

Episódio 1. A reunião destinada ao apoio institucional realizada no final do mês de outubro de 2012 tem início com um clima tenso no ar. Antes da reunião, a agitação transparecia incômodos que pareciam estar prestes a se manifestarem. $O$ estopim do conflito se deu porque a mudança dos territórios de atuação das equipes foi decidida em uma reunião de capacitação, que, diferentemente da reunião semanal com o apoiador técnico, não tinha a presença da totalidade da equipe. Como a equipe ainda não contava com veículo e outros insumos, apontou-se que um dos novos territórios poderia gerar uma superexposição. Outros acrescentam que nas últimas reuniões vinha faltando espaço para manifestações acerca das decisões. Indicam que surgiam ideias e possibilidades de construção de parcerias como, por exemplo, para compor uma oficina de cuidados; porém, que ultimamente vinha se tornando difícil oportunizá-las, porque a profissional responsável pelos contatos institucionais saiu da equipe e esta função não foi realocada. Após uma discussão acalorada, mas bastante produtiva e aberta, são estabelecidos alguns 
encaminhamentos: (a) delimitar mais precisamente os objetivos dos espaços de capacitação e de supervisão, (b) iniciar cada atividade de campo com uma rápida reunião de organização, (c) estabelecer coletivamente os princípios e os procedimentos para a suspensão da atividade em um determinado território e para a inserção em outro, (d) incentivar as oportunidades de ação autônoma da equipe no tocante à construção de parcerias, e (e) buscar insumos como folders, panfletos, preservativos etc. junto de outros pontos da rede parceiros.

Episódio 2. No início do mês de dezembro de 2012, a reunião de apoio institucional dedicou-se à avaliação do primeiro ano de atividades do CR e da ERD. Na segunda parte da reunião, os participantes são convidados a indicar, por meio de uma palavra ou de uma expressão, sua avaliação acerca do trabalho desenvolvido. Alguns destacam os impactos pessoais e profissionais: a oportunidade para quebra de tabus; a existência de uma realidade escondida pelos governos; a comoção ao ouvir os relatos de vida de pessoas em situação de rua; a oportunidade de "ver o real com lentes mais claras" (sic); a necessidade de questionar a presunção de saber do profissional de saúde. Outros participantes, por sua vez, destacam aspectos referentes à produção das ações de cuidado: as expectativas relacionadas ao início, desenvolvimento e continuidade do CR e da ERD (o processo seletivo, a falta de experiência, as primeiras atuações em campo, o entendimento da proposta, a resposta da população); a singularidade da abordagem de pessoas em situação de rua, requerendo manejar as expectativas por resultados imediatos; a preocupação em estabelecer para a própria equipe os indicadores de avaliação; a exposição ao tempo (sol, chuva, frio etc.); a intensidade das experiências no trabalho em campo: entusiasmo, angústia, medos.

Episódio 3. No mês de junho de 2013, Conselho Municipal de Saúde de Barbacena pauta, dentre 
outras questões, a prestação de contas das atividades em desenvolvimento pelos projetos do $C R$ e da ERD. São apresentadas algumas informações que foram sistematizadas como parte do apoio institucional a partir dos registros dos trabalhadores das atividades de campo: há uma concentração importante da população atendida na faixa de 30 e 40 anos; são pessoas de ambos os sexos, com discreta maioria de homens; a maior parte declara que a cor da sua pele é parda; são predominantemente solteiros ou casados; a imensa maioria não completou o ensino fundamental; fazem uso, predominantemente, de álcool, tabaco, maconha, cocaína e crack; são envolvidos em situações de risco, tais como conflito com a justiça, dependência de drogas e rompimento com a família; o uso de droga injetável é pouco frequente, mas dentre as pessoas abordadas existem usuários que afirmam compartilhar seringas; a maior parte não usa preservativo em suas relações sexuais; e parte importante não faz uso frequente dos serviços de saúde disponíveis. Atendimentos individuais e de escuta são a maioria dos procedimentos realizados, além de atividades educativas, cadastramento de usuários, participação em atividades de capacitação, encaminhamentos, distribuição de folders e panfletos, reuniões de equipe, aferição de pressão arterial, visitas domiciliares e visitas técnicas. Na oportunidade, os conselheiros questionam acerca dos critérios escolhidos para selecionar as áreas onde a equipe atuou, o que é esclarecido pela coordenadora. Várias falas reconhecem a importância e a necessidade do trabalho das equipes de CR e ERD. Os conselheiros, por fim, manifestam a um representante da Secretaria Municipal de Saúde, presente à reunião, a importância da continuidade do trabalho que vem sendo desenvolvido, mesmo após a conclusão da execução do recurso de incentivo à implantação repassado pelo Ministério da Saúde. 


\section{Considerações finais}

A democratização da saúde pautada desde pelo menos fins dos anos 1970 é uma questão que permanece atual, tanto devido à histórica cultura política brasileira, quanto no que se refere às persistentes barreiras de acesso ao sistema, mostrando a pertinência de iniciativas tais quais o apoio institucional. $\mathrm{O}$ acolhimento das necessidades de saúde de pessoas em situação de rua, segregadas por motivos diversos dos vários pontos das redes de atenção, é uma ilustração importante desta necessidade. Ainda que haja esforços neste sentido, não se pode afirmar que está superado um quadro de acentuado autoritarismo na gestão das políticas públicas. Em 2014 recordam-se os 50 anos da outorga do Ato Institucional 5, que deu início aos 20 longos anos de ditadura civil-militar em nosso país. Quando notam-se discursos que reivindicam os supostos benefícios de um regime de exceção, é possível perceber que este autoritarismo ainda reveste-se de uma "aura" virtuosa.

Além disso, as tensões entre o público e o privado nas políticas públicas são persistentes no SUS. É comum que certa ideologia gerencialista seja priorizada quando se discute a qualificação da assistência, implicando no estabelecimento de metas, prazos e resultados, medidos por número de procedimentos executados, pressupondo que o trabalhador sofre de uma indolência que lhe é inerente. Os discursos salvacionistas de "enxugamento da máquina", de "choque de gestão" e de "corte de gastos" são a outra face desta ideologia, omitindo-se que parte importante dos trabalhadores da saúde pública sofre pelos vínculos de trabalho frágeis e precários e por condições de trabalho pouco favoráveis.

$\mathrm{O}$ apoio institucional, enquanto dispositivo da $\mathrm{PNH}$, afirma a postura ético-política de promover o exercício 
do público nas políticas de saúde, assumindo este desafio mesmo diante de inúmeros obstáculos. Enfatiza a gestão compartilhada e a corresponsabilização, sem descaracterizar as responsabilidades inerentes às funções envolvidas. Apesar de tratar-se de uma função gerencial, ao promover efeitos de problematização da relação entre gestão e assistência, o apoio institucional colabora com a criação de espaços coletivos, inclusive para o manejo coletivo de tensões e conflitos. Neste processo, salienta que intervir pela melhoria do estado de saúde do outro passa necessariamente pelo cuidado de si, como se buscou ilustrar por meio do Episódio 1. Também nessa direção a questão da democratização da saúde faz sentido, pois a saúde do trabalhador da saúde trata-se de uma questão igualmente pública, e incorporar a "atividade de gestão da atividade" (BARROS; GUEDES; ROZA, 2011, p. 4808), para isso, é fundamental.

Habitualmente, o apoio institucional é convocado quando pretende-se apontar para mudanças em ações, programas ou serviços de saúde que encontram-se em andamento. $\mathrm{Na}$ experiência em relato, o dispositivo foi instituído como parte componente da estratégia de implantação de projetos de redução de danos. Colocouse um desafio duplo: contribuir com a delimitação do conteúdo da oferta assistencial junto da equipe e, ao mesmo tempo, com a elaboração de um modo de fazer esta oferta em que a produção do serviço não fosse apartada da produção de subjetividade. O Episódio 2 traz elementos que possibilitam supor que houve conquistas neste sentido. Assim, considerar a subjetividade do trabalhador na produção de ações de saúde é especialmente relevante quando se dá um contato imediato com situações de pronunciada adversidade pessoal e coletiva, de modo que espaços coletivos possibilitem a elaboração dos sentidos e dos significados das experiências vivenciadas. 
A situação retratada pelo Episódio 3 permite trazer à tona um dos efeitos deste processo, quando uma parte importante dos integrantes das equipes de CR e ERD dispõem-se a comparecer junto da coordenação de saúde mental à reunião do Conselho Municipal de Saúde para prestar contas das atividades em desenvolvimento. Àmedida que os conselheiros vão se inteirando, mais detidamente, das ações realizadas, reconhecem a relevância de se atuar junto de pessoas em situação de rua e a importância de um processo contínuo de reflexão sobre a prática. Diferentemente de "funcionários indolentes", como pode fazer supor certa ideologia gerencial, estes trabalhadores aparecem na arena pública do Conselho Municipal de Saúde como sujeitos que tomam para si a tarefa de representar publicamente o trabalho que desenvolvem.

Finalmente, vale ressaltar que o apoio institucional investe pesadamente na construção de espaços coletivos, reiterando a importância dos processos grupais como dispositivos de intervenção psicossocial. Neste sentido, tais dispositivos prestam-se não somente à mera transmissão e troca de informações, possibilitando afirmar a indissociabilidade entre o caráter educativo (formativo) e terapêutico (clínico) do grupo como processo, viabilizando a elaboração das posições individuais e coletivas dos participantes na trama social. (MACHADO, 2010; AFONSO, 2013) Assim, a aposta do apoio institucional na simultaneidade da produção de serviços e produção de sujeitos encontra plena ressonância com a aposta no potencial dos coletivos enquanto processos grupais. Em outras palavras, os grupos não são somente um espaço para transmissão ou troca de informações, mas para elaboração da relação do trabalhador com o seu trabalho, apresentandose como a pedra-de-toque do apoio institucional. 


\section{Referências}

AFONSO, M. L. M. Oficinas em dinâmica de grupo: um método de intervenção psicossocial. 3. ed. São Paulo: Casa do Psicólogo, 2013.

BARROS, M. E. B.; GUEDES, C. R.; ROZA, M. M. R. O apoio institucional como método de análise-intervenção no âmbito das políticas públicas de saúde: a experiência em um hospital geral. Ciência \& Saúde Coletiva, Rio de Janeiro, v. 16, n. 12, p. 4803-4814, 2011.

BRASIL. Ministério da Saúde. HumanizaSUS: Documento base para gestores e trabalhadores do SUS. 4. ed. Brasília: MS, 2008.

. Política Nacional de Atenção Básica. Brasília: MS, 2012.

CONILL, E. M. Ensaio histórico-conceitual sobre a Atenção Primária à Saúde: desafios para a organização de serviços básicos e da Estratégia Saúde da Família em centros urbanos no Brasil. Cadernos de Saúde Pública, Rio de Janeiro, v. 24, supl. 1, p. s7-s16, 2008.

DALLA VECCHIA, M. 0 trabalho em equipe na atenção primária à saúde: fundamentos histórico-políticos. São Paulo: Cultura Acadêmica, 2012.

FLEURY, S. (Org.) Saúde e democracia: a luta do CEBES. São Paulo: Lemos, 1997.

GUEDES, C. R.; ROZA, M. M. R.; BARROS, M. E. B. O apoio institucional na Política Nacional de Humanização: uma experiência de transformação das práticas de produção de saúde na rede de atenção básica. Cadernos de Saúde Coletiva, Rio de Janeiro, v. 20, n. 1, p. 93-101, 2012.

MACHADO, M. N. M. Intervenção psicossociológica, método clínico, de pesquisa e de construção teórica. Pesquisas e 
Práticas Psicossociais, v. 5, n. 2, p. 175-181, 2010.

PONTE, C. F.; FALLEIROS, I. (Orgs.) Na corda bamba de sombrinha: a saúde no fio da história. Rio de Janeiro: Fiocruz, 2010.

SANTOS FILHO, S.; BARROS, M. E. B.; GOMES, R. S. A Política Nacional de Humanização como política que se faz no processo de trabalho em saúde. Interface Comunicação, Saúde, Educação, Botucatu, v. 13, Supl. 1, p. 603-613, 2009.

TEIXEIRA, C. F. A mudança do modelo de atenção à saúde no SUS: desatando nós, criando laços. Saúde em Debate, Rio de Janeiro, v. 27, n. 65, p. 257-277, 2003.

VASCONCELOS, M. F. F.; MORSCHEL, A. O apoio institucional e a produção de redes: do desassossego dos mapas vigentes na Saúde Coletiva. Interface Comunicação, Saúde, Educação, Botucatu, v. 13, Supl.1, p. 729-738, 2009. 


\title{
A prática da supervisão nos serviços de saúde mental
}

\author{
Maria Wilma S. de Faria
}

Se nos detivermos um pouco no significante "supervisão", temos no prefixo "super" aquilo que indica acima ou excesso. Como poderíamos entender a prática da supervisão nos serviços? Nem super e nem visão. Qual é o lugar possível dessa prática na Saúde Mental? Porque precisamos dela? O convite aqui vai além de uma visão, tratase do convite a uma escuta. Escutar serviços, profissionais, equipe, casos clínicos, ali onde há uma carência e não um excesso de formalização.

Um dos grandes desafios que existiu para a Reforma Psiquiátrica foi o que poderíamos nomear como uma dissimetria entre a teoria e a prática. Como sabemos, a criação das redes substitutivas às internações psiquiátricas ainda carece de maior formalização teórica. Parece que o lugar da supervisão fez-se necessário para poder formalizar e suportar essa prática que está em permanente construção. Doze anos após a criação dos CAPS ad ainda deparamos com o desafio de incluir alcoolistas e toxicômanos na rede de saúde. Em muitos municípios de pequeno porte, profissionais de CAPS I relatam um "não saber o que fazer" com esse público ou mesmo apresentam resistências em 
atendê-lo juntamente com portadores de transtornos mentais em geral.

Os cuidados em saúde trazem um frequente tensionamento e disputa entre os numerosos atores que operam no interior de uma instituição: as categorias profissionais, os diversos saberes, a concepção que cada um traz da loucura ou da dependência, enfim, um vasto universo de opiniões. Essa multiplicidade ultrapassa 0 interior do serviço e toca as relações que cada profissional tem com a rede, com outros pontos da rede.

Para trabalhar em saúde mental e em especial com usuários de álcool e outras drogas, a dimensão do desejo precisa estar operando em cada profissional. Lidamos com o imprevisto, com sujeitos que têm uma impulsão muito grande, e uma tendência ao agir que os empurra ao ato de se drogar no limite onde a palavra não pode ser pronunciada. Tal fato convoca o manejo também em ato, de cada profissional e de todos, muitas vezes. É necessário desejo para lidar com o que claudica, para aceitar a dimensão "desorganizada" de apresentação dos sujeitos que, muitas vezes, na insistência da pulsão, levaos ao tênue fio das fronteiras com a morte. É necessário desejo para lidar com o que fracassa! Só é possível suportar isso quando nos despimos de um "saber prévio" do que é melhor para o outro. Nós não sabemos o que é melhor para o outro! Exercício de humildade, exercício de escuta! Algo que convoca uma medida, um limite ao excesso dos profissionais que acham saber o que é indicado e necessário para o outro. $O$ trabalho feito por muitos não se dá com um único profissional responsável pela condução do caso. Não cabe aqui aquela frase escutada com frequência: "Esse paciente não é meu! O paciente é de fulano!". Esquecendo que o paciente é de fulano, mas o paciente também é do CAPS! É da REDE! É da CIDADE! É do SUS! Mas é NOSSO! 
Nessa direção temos como tarefa ajudar o sujeito a trançar uma rede em torno de si num verdadeiro trabalho de amarração de fios que se soltam e que podem ser reamarrados. Isso não quer dizer que não precisa haver "ao menos um" que se coloque entre o sujeito e seu gozo. É necessário, sim, alguém que se responsabilize por ser esse "ao menos um", a quem o paciente possa se endereçar, alguém que consinta em oferecer às vezes o próprio corpo como anteparo entre o sujeito e seu gozo da forma menos prescritiva possível, em um lugar vazio de saber. Alguém que não consinta com sua entrega silenciosa ao gozo, mas que tente colocá-lo a trabalho, cutucando-o, provocando-o, causando algum enigma que possibilite a busca de algum sentido, mesmo provisório, para aquilo que não tem sentido.

O trabalho de supervisão, assim como o trabalho da direção de um tratamento, pede a delicadeza de uma escuta, a escuta da instituição com seus muitos movimentos, em uma dose medida. Faz-se necessário estar atento e fazer valer a interface entre o que é da clinica, entendida como o singular de cada caso; o que é da política, entendida como os princípios, diretrizes do SUS e da política de saúde mental (incluindo aí um tratamento que não se faz sozinho, mas contando com uma rede de dispositivos); e também o que é da ordem do social, entendido como os enlaçamentos possíveis de um sujeito para estar no mundo.

A escuta do supervisor deve possibilitar que 0 trabalho nos serviços substitutivos não se burocratize numa posição de mesmice, mas cause uma constante interrogação nos membros da equipe quanto ao desejo de estar ali, provocando-os, levantando perguntas sobre o que parece óbvio, e também os acolhendo. É preciso causar o desejo, algo delicado e sutil que exige uma escuta frente à infinidade de demandas trazidas pela equipe ao supervisor: 
capacitação; formação; prescrição de como funcionar; garantias; respostas; conflitos com a gerência e o gestor!

Na supervisão não deixa de haver uma transmissão, mas não aquela enfatuada, pautada em uma mestria, mas uma transmissão que possibilite a construção de um saber em torno dos casos clínicos. Geralmente são trazidos casos considerados os mais difíceis, onde um impasse se coloca, casos de pacientes que "aprontam", que interrogam o serviço, que incomodam mesmo! Trabalhar em torno do caso, no real presente no caso, na satisfação que cada sujeito retira de seu sintoma, recoloca a dimensão clínica da razão da existência da instituição. Na supervisão é possível cada profissional colocar sua angústia, seu impasse, suas incertezas e seu incômodo com o caso. Um exemplo a ser citado ocorreu quando a enfermeira de um CAPS ad, que havia iniciado recentemente o trabalho na instituição, expressou o seu horror de estar com pacientes que falavam sem parar em sua cabeça, demandando a cada minuto algo que nunca tinha fim. Pôde falar de sua experiência de anos em CTI, onde os pacientes estavam mudos, deitados e nada pediam.

É importante saber que não se trata de propor um serviço onde todos são psicanalistas, mas cuidar para que a equipe possa intervir junto aos casos graves de forma também cuidadosa, colhendo os efeitos dessa intervenção, tendo o caso clínico como eixo central. Trabalha-se na supervisão exatamente com os casos que fazem um furo no ideal da instituição e que pedem novas respostas da equipe, um manejo clínico diferente. Há um furo no saber da instituição, um convite à invenção, a operar os casos um a um sem ter que encaixar o usuário em uma regra de ouro da instituição.

O lugar que o supervisor ocupa é, assim, aquele de "dentro/fora", alguém que faz parte da equipe, mas está 
fora da mesma, em "íntima exterioridade", o que pode trazer às vezes certo desassossego à equipe em seus momentos de cochilo. Chamo aqui de cochilo, os momentos de acomodação. Não é porque um serviço é chamado de substitutivo que ele não possa cronificar seus usuários, mantendo-se fechado para mudanças, burocratizado e inerte na repetição sintomática da equipe!

Quando alguém é convidado para ser supervisor não tem a mínima ideia do que será produzido, mas também precisa estar aberto a aprender com a experiência dos profissionais que ali trabalham e com o que ensina o caso clínico.

Sabemos que não há umúnico modo de funcionamento do serviço, um padrão a ser seguido. Cada serviço, à sua maneira, dentro das particularidades regionais, pode e deve operar de acordo com a sua realidade. $O$ supervisor não deve estar ao lado da gerência, da chefia, de uma categoria profissional, do coordenador de saúde mental ou do prefeito de um município. Deve ser regulado pela ética, pelos princípios do SUS, pela Saúde Mental, pela Reforma e pela Clínica. $O$ ato pode estar assim também do lado do supervisor! Este não pode consentir, por exemplo, no trabalho de um CAPS que funciona como um grande ambulatório, deixando os casos graves desassistidos e sendo enviados para um hospital psiquiátrico.

Também não cabe algo escutado com frequência: " $O$ paciente não tem perfil para o nosso serviço! O paciente não tem demanda"! Ora, nós é que temos que nos desdobrar e nos adaptar ao funcionamento de cada sujeito, à sua maneira. Se o paciente fosse bem adaptado ele não precisaria contar com o nosso trabalho! Cabe aqui cuidar dos aspectos morais envolvendo a loucura, a repetição, as crises e recaídas, questionando o conceito de cura. Falas como: "esse aí não quer parar de beber; não quer 
nada com a dureza; você está enxugando gelo; ele vem à Permanência dia por causa do ganho secundário; vamos dar alta e transferi-lo para outro lugar por que não se adapta ao nosso serviço", muitas vezes atravessam o cotidiano dos serviços, fazendo ruído, paralisando a equipe, deixando-a na impotência e atirando o sujeito a léguas de distância, à margem do serviço e do tratamento. $O$ supervisor tem como tarefa convocar o não-todo do saber e, ao mesmo tempo, responsabilizar cada um por colocar algo de si na construção de um novo saber.

\section{O Cotidiano da Clínica e da Supervisão}

A clínica com usuários de álcool e outras drogas convida por excelência cada profissional a refletir sobre sua concepção pessoal do que é a dependência, o alcoolismo, a toxicomania. Isso toca valores, conceitos, pré-conceitos e traz à luz questões éticas. As diferentes concepções podem gerar diferentes formas de tratamento. Se um determinado profissional acha que um alcoolista é uma pessoa "fraca, sem vergonha e sem força de vontade" isso gera uma forma de abordagem. Se outro profissional pensa que um usuário de drogas é um "delinquente e bandido" isso também não é sem consequências para o tratamento. Mas se considerarmos o dependente como um sujeito de responsabilidade, inclusive responsável pelo ato de se drogar, um sujeito de direito, um cidadão, uma nova abordagem se dá. Muitas vezes em supervisão pontos delicados dessa natureza precisam ser trabalhados.

Em uma supervisão em um CAPS ad foi escutado que o porteiro era o responsável por autorizar a entrada dos usuários na Permanência Dia (PD) do serviço. Ele é quem 
"avaliava" se um paciente estava ou não em condições de entrar. Sabemos do quão importante é a presença de um porteiro no trabalho de uma equipe, sua forma de receber os usuários expressa o funcionamento do serviço. O que foi questionado aqui foi a responsabilidade delegada a ele de autorizar/avaliar a entrada de um usuário no serviço. Um CAPS ad que tenha como regra não deixar nunca um paciente alcoolizado entrar no serviço pode incorrer no risco de deixar aqueles casos mais graves fora da instituição, desassistidos e atender apenas os casos que "não dão trabalho". Uma equipe que não toma o caso para si, que não acolhe um usuário em crise, que não o escuta, não está operando em sua dimensão clínica.

Esta dimensão ensina que o abuso de substâncias é da ordem do singular, que a droga e o álcool cumprem uma função na economia psíquica de cada sujeito. Dessa forma o enfoque não pode ser dado às drogas e sim ao sujeito. A escuta cuidadosa de sua história, de como se deu o primeiro encontro com as substâncias, em quais momentos recorre a elas, quando as mesmas deixaram de ser uma solução e passaram a ser um problema em sua vida, são orientadores preciosos para quem se dispõe a acompanha-lo. Não trabalhamos com categorias ou classificações, que tendem a generalizar, como se a dependência fosse uma entidade única para todos. Entendendo que estamos em um terreno que toca aquilo que é da ordem pulsional, mais forte que o sujeito, que o empurra ao pior e sobre o qual não tem controle, torna possível à equipe lidar com as recaídas, com a circulação do paciente sempre demandando tratamento e depois abandonando o mesmo.

Todas as instituições, para seu bom funcionamento, pautam-se por regras e normas. Em um CAPS ad supervisionado, existia um cartaz que ia do chão ao teto com uma imensa lista de proibições. Em que pese o fato 
de que esta lista tenha sido construída com os usuários, havia um desconhecimento do quanto o "supereu" dos alcoolistas e toxicômanos é severo. Quanto maior a proibição, maior a transgressão e o empuxe ao consumo se apresenta. Dessa maneira a culpa se presentifica e empurra o sujeito novamente ao consumo em uma circularidade sem sentido. Assim, um número significativo dessas proibições não era cumprido, o que gerava um desgaste constante e um embate entre os usuários e a equipe. A experiência ensina que as regras devem ser o menos rígidas possíveis. É importante para o funcionamento de uma instituição o suportar a existência de uma lei que inclua a exceção, o caso a caso, o momento clínico do paciente.

Um pequeno fragmento ilustra a importância da singularidade. Uma paciente alcoolista saiu às 21 horas do CAPS e voltou embriagada às 11 horas da manhã seguinte. Em um primeiro momento, a equipe, sem mesmo escutá-la, quis barrar sua entrada, uma vez que o horário marcado para seu retorno era as $14 \mathrm{~h} 30$. Uma técnica de enfermagem optou por acolhê-la e escutar o que se passava. Foi quando tomou conhecimento de que a mãe da paciente havia falecido na tarde anterior. Ela havia passado a noite e a madrugada no velório bebendo e enterrado a mãe às 9 horas. Acolhê-la assim, do jeito que podia estar, endereçando um pedido de ajuda, foi de fundamental importância em seu tratamento.

Em um CAPS I de uma cidade de pequeno porte encontramos uma total falta de lei. $\mathrm{O}$ trabalhar de "portas abertas" era interpretado literalmente em a porta ficar escancarada. O usuário chegava e saía quando bem queria, tomava "uma" na praça em frente, voltava embriagado, tudo isso sem a menor consequência. Os usuários se relacionavam com o serviço como a "Casa de mãe Joana", não havendo ninguém para interpelar, para barrar, para fazer com que isso retornasse para o sujeito em forma 
de pergunta. Algo com o que o supervisor não poderia consentir.

Inúmeras questões permeiam um trabalho de supervisão. Questões como: Se muitos usuários tomam medicação, qual o problema de se instituir um horário de "cochilo" após o almoço? Se um usuário de drogas só vai à instituição para comer e dormir ele é um "folgado"? Qual é o lugar da Permanência Dia para o tratamento de um paciente no CAPS? Quando se indica a PD? E para que? Para reduzir os danos? Para afastar o usuário da "boca"? Quais as razões que justificam uma oficina ser de caráter "obrigatório" e não opcional? A realização de Oficinas é uma oferta para passar o tempo? A quem compete coordenar uma oficina? Cuidar do corpo devastado pela droga pode ser o início de uma estratégia de cuidado que visa em um segundo momento, a retificação desse sujeito sobre sua posição? O que a instituição está fazendo para causar em cada usuário a pergunta necessária: "a que a droga está servindo em minha vida"? Sabemos que não há uma regra de ouro, uma resposta pronta, mas perguntas, questões, momentos clínicos que funcionam de uma forma para um, de outra forma para outro. Tais questões, ao permearem o cotidiano do trabalho, são muito importantes. Quando lançadas por um profissional, um técnico de referência, uma equipe, tornam a instituição viva! 


\section{Para não concluir}

A política do desejo possibilita aos dependentes de álcool e outras drogas construírem saídas as mais diversas e inusitadas possíveis. É nossa tarefa ética possibilitar para cada sujeito um lugar na cidade, na vida, dentro de si, uma maneira possível de caber no laço social.

Podemos pensar que há um excesso em cada instituição, excesso de não querer saber; excesso de querer o bem; excesso de fazer as regras e as normas funcionarem; excesso até mesmo de protocolos e procedimentos. O lugar da supervisão pede menos visão e mais escuta e pode viabilizar uma dose necessária ao funcionamento de um serviço. 


\section{Sobre os Autores}

Aisllan Assis - Enfermeiro pela Universidade Federal de Mato Grosso. Especialista em Enfermagem Psiquiátrica e Saúde Mental pelo Hospital Universitário Pedro Ernesto (HUPE) da Universidade do Estado do Rio de Janeiro (UERJ). Mestre em Saúde Coletiva, área de política, planejamento e administração em saúde, pelo Instituto de Medicina Social/ UERJ. Busca atuar como profissional de saúde coletiva nos diferentes níveis, serviços e ensino da saúde. Email: aisllandiego@hotmail.com

Ana Cecília Villela Guilhon - Psicóloga graduada pela UFRJ. Estagiária do Hôpital Marmottan (Paris - França). Especialista em Psicologia Clínica e Psicopatológica pela Sorbonne (Paris - França). Mestre em História e Filosofia da Psicologia (UFJF). Psicóloga do Departamento de Saúde Mental de Juiz de Fora. Presidente do Conselho Municipal de Políticas Integradas sobre Drogas de Juiz de Fora (COMPID). Email: anaceciliajf@gmail.com

Claudia Ciribelli Rodrigues Silva - Graduação em Psicologia pela Universidade Federal de Juiz de Fora. Mestrado em Saúde Coletiva pelo Instituto de Medicina Social da Universidade do Estado do Rio de Janeiro. Psicanalista e professora da Universidade Salgado de Oliveira. Email: claudiaciribelli@yahoo.com.br 
Claudia Henschel de Lima - Graduação em Psicologia pela Universidade Federal do Rio de Janeiro. Mestre em Teoria Psicananalítica (UFRJ). Doutora em Psicologia Social e da Personalidade(UFRJ).ProfessoraAdjuntolldoDepartamento de Psicologia - Instituto de Ciências Humanas e Sociais de Volta Redonda - Universidade Federal Fluminense. (UFF. ICHS. PUVR). Coordenadora do Laboratório de Investigação das Psicopatologias Contemporâneas (LAPSICON. UFF. ICHS. PUVR). Membro da Associação Universitária de Pesquisa em Psicopatologia Fundamental (AUPPF). Membro da Escola Brasileira de Psicanálise (EBP) e da Associação Mundial de Psicanálise (AMP). Email: claudiahlima@vm.uff.br

Denis da Silva Petuco - Redutor de danos e educador popular. Cientista Social (UFRGS), Mestre em Educação (UFPB), doutorando em Ciências Sociais (UFJF). Tem contribuído com a difusão de práticas de Redução de Danos em todo o país. Atualmente, compõe a equipe nacional do projeto Caminhos do Cuidado. denis.petuco@gmail.com

Flávia Fernando Lima Silva - Médica (UFCG), Psiquiatra (residência no Hospital Juliano Moreira, Salvador, Bahia), Psicoterapeuta e Especialista em Psiquiatria da Infância e Adolescência (UFRGS). Especialista em Análise Institucional pela Fundação Gregório Baremblitt de Minas Gerais. Mestre em Estudos da Subjetividade, PPG de Psicologia, Universidade Federal Fluminense (UFF). Atualmente trabalha na rede de atenção psicossocial do Rio de Janeiro, no CAPS ad Júlio César de Carvalho. Email: flavia_fernando@ yahoo.com.br

lacã Macerata - Psicólogo. Mestre em Psicologia (UFF). Doutorando em psicologia pela Universidade Federal Fluminense. Integrante do grupo de pesquisa "Cognição e Subjetividade" (CNPQ) e do grupo de pesquisa "Enativos: Produção de cuidado e conhecimento" (UFF). Psicólogo Clínico. Email: imacerata17@gmail.com 
Marcelo Dalla Vecchia é Mestre e Doutor em Saúde Coletiva, Professor do Departamento de Psicologia da Universidade Federal de São João del-Rei, membro do Conselho Municipal de Políticas sobre Drogas de São João del-Rei - COMAD - e da Comissão de Direitos Humanos do Conselho Regional de Psicologia - 4a região.

Maria Wilma Santos de Faria - Psicóloga. Terapeuta Ocupacional. Especialista em Saúde Mental pela Escola de Saúde Pública de Minas Gerais. Psicanalista. Membro da Escola Brasileira de Psicanálise (EBP) e da Associação Mundial de Psicanálise (AMP). Terapeuta do CAPS ad II Centro Mineiro de Toxicomania da Fundação Hospitalar do Estado de Minas Gerais (FHEMIG). Supervisora de CAPS pelo Ministério da Saúde. Email: mwilma62@gmail.com

Martinho Silva - Graduado em Psicologia (UNB). Especialista em Saúde Mental em Nível de Residência (ENSP/FIOCRUZ). Mestre em Saúde Coletiva (Instituto de Medicina Social/ Universidade do Estado do Rio de Janeiro - IMS/UERJ). Doutor em Antropologia Social (MN/UFRJ). Professor do IMS/UERJ, no Departamento de Ciências Humanas e Saúde. Email: silmartinho@gmail.com

Pedro Henrique Antunes da Costa - Psicólogo. Mestre e Doutorando em Psicologia pela Universidade Federal de Juiz de Fora (UFJF). Pesquisador do Centro de Referência em Pesquisa, Intervenção e Avaliação em Álcool e outras Drogas (CREPEIA). Integrante do Centro Regional de Referência sobre Drogas de Juiz de Fora e região (CRR-JF). Email: phantunes.costa@gmail.com

Rafael Mendonça Dias Psicólogo. Doutor em Psicologia pela Universidade Federal Fluminense (2013). Professor do Centro Universitário Hermínio da Silveira (IBMR) e pesquisador da organização de direitos humanos Justiça Global. E-mail: sendeiro@gmail.com 
Tatiana Ramminger - Psicóloga. Mestre em Psicologia Social e Institucional (UFRGS). Doutora em Saúde Pública (ENSP/ FIOCRUZ). Professora do Departamento de Psicologia Instituto de Ciências Humanas e Sociais de Volta Redonda - Universidade Federal Fluminense. Integrante do Grupo de Pesquisa REDESAUDE: rede de compartilhamento, pesquisa e intervenção e do Observatório de Políticas Públicas em Saúde e Cuidado da Região do Médio Paraíba do Rio de Janeiro.

Ygor Alves - Antropólogo graduado pela Pontifícia Universidade Católica de São Paulo (1993) e mestre em Ciências Sociais pela mesma instituição (1998). Docente do nível superior desde 1997, é doutorando no Programa de Pós-Graduação em Antropologia da UFBA. No momento, realiza pesquisa observação participante entre usuários de crack na região central da cidade de São Paulo. Email: antropologiaygor@yahoo.com.br 


\section{$\| .||||$ \\ Lançamentos \\ Editora Rede UNIDA 2015}

\section{Série Micropolítica do Trabalho e o Cuidado em Saúde}

Tecnologias leves em saúde: saberes e práticas da Residência Multiprofissional na Estratégia Saúde da Familia

Orgs. Maria Socorro de Araújo Dias, Márcia Maria Santos da Silva, Francisca Lopes de Souza, Ana Karina de Sousa Gadelha e Elyudienne Andressa Silva Alves

O cuidado e a educação popular em saúde Org. Luciano Bezerra Gomes

O cuidado em saúde aprendendo com a morte Orgs. Ana Lúcia Abrahão e Emerson Elias Merhy

Lavoro della salute: micropolíticas e cartografias Orgs. Túlio Batista Franco e Emerson Elias Merhy

Gestão em saúde: cartografias do apoio Org. Laura Feuerwerker

editora

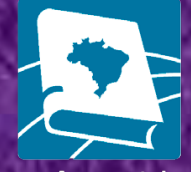

rede unida

www.redeunida.org.br 